


\title{
Risicobeoordeling waterverstrekking aan vleeskuikens en vleeskuikenouderdieren
}

I.C. de Jong ${ }^{1}$, J. van Harn $^{1 *}$, P. Koene ${ }^{1 *}$, H. Ellen ${ }^{1}$, R.A. van Emous ${ }^{1}$, J.M. Rommers ${ }^{1}$, H. van den Brand ${ }^{2}$

\author{
${ }^{1}$ Wageningen University and Research, Wageningen Livestock Research \\ ${ }^{2}$ Wageningen University and Research, Leerstoelgroep Adaptatiefysiologie \\ *]. van Harn en P. Koene hebben in gelijke mate bijgedragen aan het rapport
}

Dit onderzoek is uitgevoerd door Wageningen Livestock Research, in opdracht van en gefinancierd door de Nederlandse Voedsel- en Warenautoriteit, Ministerie van Economische Zaken, in het kader van onderzoek door Bureau Risicobeoordeling en Onderzoeksprogrammering (BuRO).

Wageningen Livestock Research

Wageningen, december 2016

Rapport 989 
I.C. de Jong, J. van Harn, P. Koene, H. Ellen, R.A. van Emous, J.M. Rommers, H. van den Brand, 2016. Risicobeoordeling watervertrekking aan vleeskuikens en vleeskuikenouderdieren; Risk assessment of water provision for broilers and broiler breeders. Wageningen Livestock Research, rapport 989.

Samenvatting NL Dit rapport beschrijft de wijze van water verstrekken in de commerciële houderij van vleeskuikens en vleeskuikenouderdieren en de mogelijke impact daarvan op het dierenwelzijn (inclusief diergezondheid). Het geeft een overzicht van natuurlijk drinkgedrag, de fysiologie van de wateropname bij kippen en factoren van invloed op de waterconsumptie. Op basis van literatuur en expert opinie wordt ingeschat dat de wijze van water verstrekken aan vleeskuikens geen impact heeft op het dierenwelzijn. Experts schatten in dat de wijze van water verstrekken aan vleeskuikenouderdieren mogelijk wel impact heeft op het dierenwelzijn maar kennis ter onderbouwing van deze conclusie ontbreekt grotendeels. Beschreven wordt welke maatregelen genomen kunnen worden om het risico op ongerief bij vleeskuikens en vleeskuikenouderdieren zo beperkt mogelijk te houden. Als laatste worden aanbevelingen voor verder onderzoek gedaan.

Summary UK This report describes the methods of water provision in the current housing and management of broilers and broiler breeders and the possible impact of these management practices on animal welfare (including animal health). It provides an overview of drinking behavior of chickens, the physiology of water intake and factors affecting water consumption in broilers and broiler breeders. Based on scientific literature and expert opinion it is estimated that the current methods of water provision to broiler chickens do not have an effect on welfare. The current methods of water provision to broiler breeders are estimated to affect broiler breeder welfare, but evidence from scientific literature is lacking. It is described which management methods can be applied to reduce the welfare impact of water provision to broilers and broiler breeders. Finally, recommendations for further research are provided.

Dit rapport is gratis te downloaden op http://dx.doi.org/10.18174/397955 of op www.wur.nl/livestock-research (onder Wageningen Livestock Research publicaties).

(C) 2016 Wageningen Livestock Research

Postbus 338, 6700 AH Wageningen, T 03174839 53, E info.livestockresearch@wur.nl, www.wur.nl/livestock-research. Wageningen Livestock Research is onderdeel van Wageningen University \& Research.

Wageningen Livestock Research aanvaardt geen aansprakelijkheid voor eventuele schade voortvloeiend uit het gebruik van de resultaten van dit onderzoek of de toepassing van de adviezen.

Alle rechten voorbehouden. Niets uit deze uitgave mag worden vermenigvuldigd en/of openbaar gemaakt worden door middel van druk, fotokopie, microfilm of op welke wijze dan ook zonder voorafgaande toestemming van de uitgever of auteur.

De certificering volgens ISO 9001 door DNV onderstreept ons kwaliteitsniveau. Op als onze onderzoeksopdrachten zijn de Algemene Voorwaarden van de Animal Sciences Group van toepassing. Deze zijn gedeponeerd bij de Arrondissementsrechtbank Zwolle.

Wageningen Livestock Research Rapport 989 


\section{Inhoud}

$\begin{array}{lr}\text { Samenvatting } & 7\end{array}$

$1 \quad$ Inleiding $\quad 9$

$\begin{array}{llr}1.1 & \text { Doelstelling } & 9\end{array}$

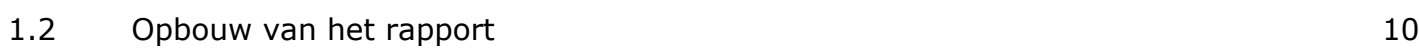

2 Methoden $r$

$\begin{array}{lll}2.1 & \text { Literaturonderzoek } & 11\end{array}$

2.2 Risico inventarisatie $\quad 11$

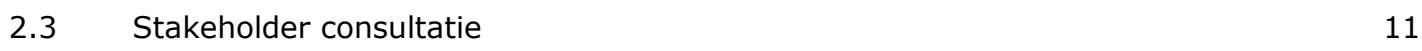

2.4 Internationale experts $\quad 12$

$\begin{array}{llr}3 & \text { Wateropnamegedrag } & 13\end{array}$

4 De fysiologie van de waterhuishouding bij kippen $\quad 16$

$\begin{array}{lll}4.1 & \text { Wateropname } & 16\end{array}$

$\begin{array}{lll}4.2 & \text { Waterverlies } & 17\end{array}$

$\begin{array}{lll}4.3 & \text { Hoe kan de waterstatus gemeten worden } & 18\end{array}$

4.3.1 Het hele kuiken $\quad 18$

$\begin{array}{ll}\text { 4.3.2 De excreta } & 19\end{array}$

$\begin{array}{ll}\text { 4.3.3 Bloedwaarden } & 19\end{array}$

$\begin{array}{lll}\text { 4.3.4 Pathologische afwijkingen } & 20\end{array}$

4.3.5 Praktisch toepasbare indicatoren om de waterstatus van een dier of koppel
te bepalen

$5 \quad$ Factoren van invloed op de waterconsumptie $\quad 22$

$\begin{array}{llr}5.1 & \text { Dierfactoren } & 22\end{array}$

\begin{tabular}{ll}
5.1 .1 & Genetische achtergrond \\
\hline
\end{tabular}

$\begin{array}{ll}5.1 .2 & 23\end{array}$

$\begin{array}{lll}5.1 .3 & \text { Gezondheidsstatus } & 23\end{array}$

$\begin{array}{ll}5.1 .4 & 23\end{array}$

$\begin{array}{lll}5.1 .5 & \text { Sociale facilitatie } & 24\end{array}$

\begin{tabular}{ll}
5.1 .6 & Adaptatie \\
\hline
\end{tabular}

$\begin{array}{lll}5.2 & \text { Waterkwaliteitsfactoren } & 24\end{array}$

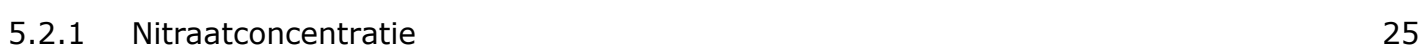

\begin{tabular}{ll}
5.2 .2 & Smaak \\
\hline
\end{tabular}

$\begin{array}{lll}5.2 .3 & \text { Reuk } & 25\end{array}$

$\begin{array}{lll}5.2 .4 & \text { Visuele verontreiniging } & 26\end{array}$

$\begin{array}{lll}5.2 .5 & \text { Elektrolyten } & 26\end{array}$

$\begin{array}{lll}5.3 & \text { Voedingsfactoren } & 26\end{array}$

$\begin{array}{lll}5.3 .1 & \text { Voersamenstelling } & 26\end{array}$

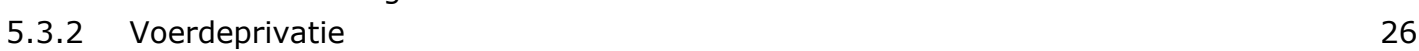

$\begin{array}{lll}5.4 & \text { Huisvestings- en managementfactoren } & 27\end{array}$

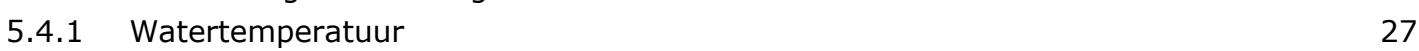

\begin{tabular}{ll}
5.4 .2 & Waterdruk \\
\hline
\end{tabular}

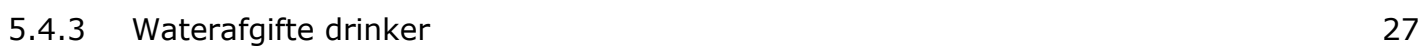

$\begin{array}{lll}5.4 .4 & \text { Drinker type } & 28\end{array}$ 
$\begin{array}{llr}\text { 5.4.5 Drinker hoogte } & 28\end{array}$

$\begin{array}{llr}5.4 .6 & \text { Waterverspilling } & 28\end{array}$

\begin{tabular}{ll}
5.4 .7 & Omgevingstemperatuur \\
\hline
\end{tabular}

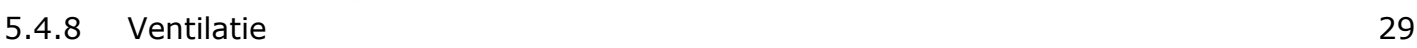

\begin{tabular}{ll}
5.4 .9 & Relatieve luchtvochtigheid \\
\hline 5.5 & 29
\end{tabular}

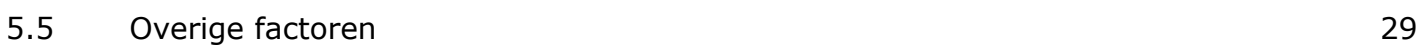

\begin{tabular}{ll}
5.5 .1 & Licht en lichtregime \\
\hline
\end{tabular}

$\begin{array}{ll}5.5 .2 & \text { Bezettingsdichtheid } \\ \end{array}$

6 Methoden van waterverstrekking aan vleeskuikens en vleeskuikenouderdieren $\begin{array}{ll}\text { en het effect op dierenwelzijn } & 31\end{array}$

$\begin{array}{lll}6.1 & \text { Vleeskuikens } & 31\end{array}$

$\begin{array}{ll}\text { 6.1.1 De praktijk in Nederland } & 31\end{array}$

6.1.2 Effect van beperking van de watergift op het welzijn van vleeskuikens 32

6.1.3 Risico inventarisatie methoden van waterbeperking/gecontroleerd verstrekken van water aan vleeskuikens $\quad 33$

$\begin{array}{lll}6.2 & \text { Vleeskuikenouderdieren } & 34\end{array}$

$\begin{array}{lll}\text { 6.2.1 De praktijk in Nederland } & 34\end{array}$

6.2.2 Effect van waterbeperking of onbeperkte waterverstrekking op het welzijn van vleeskuikenouderdieren $\quad 36$

6.2.3 Risico inventarisatie methoden van waterbeperking bij vleeskuikenouderdieren 37

$7 \quad$ Stakeholderconsultatie

7.1 Methoden van waterbeperking/gecontroleerd water verstrekken bij vleeskuikens 39

7.2 Methoden van waterbeperking/gecontroleerd water verstrekken bij vleeskuikenouderdieren

$\begin{array}{lll}\text { 7.3 } & \text { Factoren van invloed op de wateropname } & 41\end{array}$

8 Discussie en mogelijke maatregelen $\quad 44$

8.1 Ongerief door beperkte waterverstrekking aan vleeskuikens 44

8.1.1 Randvoorwaarden ter voorkoming van ongerief door beperkte waterverstrekking aan vleeskuikens $\quad 45$

8.2 Vleeskuikenouderdieren 45

8.2.1 Maatregelen ter voorkoming van ongerief door beperkte waterverstrekking aan vleeskuikenouderdieren $\quad 46$

9 Conclusies en aanbevelingen $\quad 47$

$\begin{array}{lll}9.1 & \text { Vleeskuikens } & 47\end{array}$

$\begin{array}{lll}9.2 & \text { Vleeskuikenouderdieren } & 47\end{array}$

$\begin{array}{lr}\text { Literatuur } & 49\end{array}$ 


\section{Woord vooraf}

Het onderzoek beschreven in dit rapport is tot stand gekomen na een opdracht van Nederlandse Voedsel- en Warenautoriteit, Ministerie van Economische Zaken. Doordat binnen de geldende wetgeving de eisen gesteld aan de watervoorziening die niet éénduidig benoemd zijn, is de vraag gekomen om dit beter te duiden. Dit rapport beschrijft de wijze van water verstrekken in de commerciële houderij van vleeskuikens en vleeskuikenouderdieren en de mogelijke impact daarvan op het dierenwelzijn. Dit rapport geeft een overzicht van natuurlijk drinkgedrag, de fysiologie van de wateropname bij kippen en factoren van invloed op de waterconsumptie.

Omdat op voorhand werd verwacht dat een aantal vragen niet op basis van literatuuronderzoek te beantwoorden zijn, zijn stakeholders en internationale experts gevraagd om medewerking aan dit rapport te verlenen. De constructieve medewerking en input van een aantal stakeholders en internationale experts uit de relevante sectoren, in interviews en enquêtes, is een zeer waardevolle en noodzakelijke bijdrage aan het project daar willen we hen voor bedanken.

Wij hopen dat de uitkomsten van het project bijdragen aan het duiden van de mate en manier van waterverstrekking aan vleeskuikens en vleeskuikenouderdieren en de mogelijke gevolgen daarvan voor het dierenwelzijn.

Dr. Annemarie Rebel

Afdelingshoofd Dierenwelzijn en gezondheid 


\section{Samenvatting}

Water is één van de belangrijkste bestanddelen van het lichaam van een dier en dus ook van pluimvee. Het lichaam van een volwassen kip bestaat voor ongeveer $60 \%$ uit water, waarvan ongeveer twee derde extracellulair water is en één derde intracellulair water. Om de waterhoeveelheid in het lichaam in stand te houden is drinken van groot belang. Drinkgedrag van kippen is sterk verbonden met foerageergedrag; wanneer er geen toegang is tot water zullen kippen weinig of geen voer eten en als kippen geen toegang hebben tot voer zullen ze weinig water drinken.

Kippen nemen bij voorkeur water op uit open drinkwatersystemen, waarbij ze de karakteristieke schepbeweging kunnen maken. Om vermorsing te beperken wordt in de praktijk gebruik gemaakt van drinknippels, waarbij kippen meer moeite moeten doen om een zelfde hoeveelheid water op te nemen in vergelijking met open drinksystemen (ronddrinkers of drinkcups). Daarbij is de hoogte van de drinker van belang, waarbij de voorkeur van de kip uitgaat naar een lage drinker vanwege de natuurlijke schepbeweging om water op te nemen. Deze schepbeweging is niet mogelijk bij drinknippels, en uit een zeer laag hangende nippel kan een kip moeilijk water opnemen. Een systeem van nippels met opvangschoteltjes is meest effectief om vermorsing te voorkomen. Het meest gangbare drinksysteem bij vleeskuikens is de drinknippel, al dan niet voorzien van een opvangschotel. Drinknippels worden ook bij de meerderheid van de opfok- en vermeerderingsbedrijven met vleeskuikenouderdieren toegepast. Bij de overige opfok- en vermeerderingsbedrijven worden ronddrinkers gebruikt of worden beide systemen toegepast. Richtlijnen voor het aantal kippen per drinker zijn afhankelijk van type, diameter en waterafgifte van de drinker. Richtlijnen hiervoor worden niet beschreven in de wetenschappelijke literatuur, maar wel in brochures en managementgidsen voor de praktijk en zijn waarschijnlijk gebaseerd op 'best practice'.

De waterstatus van het dier kan op verschillende manieren gemeten worden, in het hele dier, aan de excreta en in het bloed, maar een praktisch haalbare en valide indicator ontbreekt tot nu toe. Indicatoren die zich, na verdere studie, mogelijk lenen voor toepassing in de praktijk zijn de wateropname na een periode van onthouding (compensatoire opname) en het hematocrietgehalte, plasma $\mathrm{Cl}^{-}$of creatinine gehalte in het bloed. Dehydratatie door langdurige waterdeprivatie is postmortem vast te stellen door nieraantasting en stapeling van urinezuurkristallen in diverse organen.

Er zijn vele factoren van invloed op de waterconsumptie, maar de effecten daarvan zijn niet allemaal even goed beschreven in de wetenschappelijke literatuur. Factoren die de waterconsumptie beïnvloeden zijn de genetische achtergrond, leeftijd, gezondheidsstatus, lichaamstemperatuur, sociale facilitatie en adaptatie (dierfactoren), waterkwaliteit (o.a. vorming van biofilm), voedingsfactoren (concentraties mineralen en ruw eiwit, maar ook voerdeprivatie), en huisvestings- en managementfactoren (watertemperatuur, waterdruk, waterafgifte van de drinker, drinker type, drinker hoogte, waterverspilling, omgevingstemperatuur, ventilatie, relatieve luchtvochtigheid, lichtsterkte, lichtregime en de bezettingsdichtheid). Verder onderzoek naar het effect van deze factoren (afzonderlijk en in interactie) op de waterconsumptie is noodzakelijk.

Op de meeste vleeskuikenbedrijven wordt waterbeperking, door het dichtzetten van de kraan, niet of maar gedurende zeer korte tijd in de lichtperiode toegepast. De watergift aan vleeskuikens wordt echter op de meeste vleeskuikenbedrijven wel gecontroleerd door het toepassen van maatregelen zoals het verlagen van de waterdruk, het invoegen van een donkerperiode of verlagen van de lichtintensiteit, of het toevoegen van drinkwateradditieven. De reden van deze gecontroleerde watergift is het voorkomen van een te hoge waterconsumptie en -vermorsing, waardoor de strooiselkwaliteit op peil blijft en welzijnsproblemen gerelateerd aan de strooiselkwaliteit, zoals contact dermatitis (voetzoollaesies, hakdermatitis en borstirritatie) en respiratoire aandoeningen, worden voorkomen. Er is geen wetenschappelijke literatuur beschikbaar over het effect van deze methoden van gecontroleerde watergift op het welzijn van vleeskuikens. Experts schatten in dat de impact van deze methoden op het welzijn van het kuiken afwezig is mits ze op de juiste wijze worden toegepast. 
Waterbeperking wordt op de meeste vleeskuikenouderdierbedrijven (opfok- en vermeerderingsbedrijven) toegepast door een vaste water:voer verhouding of een vast aantal uren water gedurende de dag. De reden hiervoor is het voorkomen van vermorsing of 'overdrinking', wat een negatief effect heeft op de strooiselkwaliteit. Dit kan een gevolg zijn van stereotiep pikken naar de drinknippel bij beperkt gevoerde vleeskuikenouderdieren. Hoewel er op basis van wetenschappelijke literatuur geen aanwijzingen zijn dat waterbeperking bij vleeskuikenouderdieren een negatief effect heeft op het welzijn, geven experts aan dat er mogelijk wel impact op het welzijn is.

Stakeholders geven aan dat onbeperkte waterverstrekking bij vleeskuikenouderdieren mogelijk is zonder negatieve effecten op het welzijn als gevolg van vermorsing of overmatige consumptie. Bovendien zijn er aanwijzingen uit de wetenschappelijke literatuur dat het risico op overmatige consumptie en verspilling bij onbeperkte waterverstrekking aan beperkt gevoerde vleeskuikenouderdieren beperkt is, hoewel het aan te bevelen is dit nader te onderzoeken. Dit laatste geldt ook voor het effect van methoden van waterbeperking op het welzijn van vleeskuikenouderdieren. Ouderdieren van trager groeiende vleeskuikenrassen die niet in hun voeropname beperkt hoeven worden, hoeven ook niet in hun wateropname beperkt te worden. Stereotiep pikgedrag naar de drinker is bij deze dieren afwezig en daarmee het risico op vermorsing of te hoge opname. Wanneer vleeskuikenouderdieren verdund voer krijgen, neemt het stereotiep pikgedrag ook af en daarmee het risico op overmatige waterconsumptie of watervermorsing.

Voor zowel vleeskuikens als vleeskuikenouderdieren wordt aangegeven dat factoren zoals de hoogte van de drinklijn, de afstand tot de drinkers en de beschikbaarheid van voldoende drinkpunten van belang zijn om de mogelijke negatieve gevolgen van waterbeperking of watercontrole te reduceren, door het voorkomen van competitie tussen dieren wanneer water beschikbaar komt en het mogelijk maken van synchroon drinken.

Op basis van deze studie wordt het volgende geconcludeerd:

1. Kippen nemen bij voorkeur water op uit open drinksystemen, door middel van de karakteristieke schepbeweging. Om vermorsing, en als gevolg daarvan nat strooisel, te voorkomen wordt in de praktijk meestal gebruik gemaakt van drinknippels, waarbij de kippen niet de karakteristieke schepbeweging kunnen maken;

2. De wateropname bij kippen is in hoge mate gecorreleerd aan de voeropname;

3. Het meten van dehydratatie aan het dier of in het bloed is mogelijk, maar een praktisch toepasbare methode is nog niet beschikbaar. Onderzoek om een in de praktijk bruikbare en valide test voor dehydratatie te ontwikkelen wordt daarom aanbevolen;

4. Waterbeperking (het dichtdraaien van de kraan gedurende een langere periode in de lichtperiode) bij vleeskuikens vindt nauwelijks plaats, maar gecontroleerde waterverstrekking wordt op het grootste deel van de bedrijven wel toegepast om vermorsing en nat strooisel te voorkomen. Experts schatten dat gecontroleerde waterverstrekking bij vleeskuikens in de Nederlandse praktijk geen impact op het welzijn heeft mits aan een aantal randvoorwaarden (goed bereikbare en voldoende drinkers en drinklijnen op de juiste hoogte) wordt voldaan. De expert schatting kan worden gevalideerd door onder praktische of experimentele omstandigheden te onderzoeken of de in Nederland toegepaste methoden van gecontroleerde waterverstrekking ongerief of dehydratatie bij vleeskuikens veroorzaken;

5. Waterbeperking bij vleeskuikenouderdieren wordt toegepast om overmatig drinken en/of vermorsing door stereotiep pikken naar de drinker te voorkomen, maar het lijkt mogelijk te zijn om onbeperkt water te verstrekken aan deze dieren. Experts schatten dat waterbeperking bij vleeskuikenouderdieren zoals nu toegepast in Nederland een negatieve impact op het welzijn heeft. Deze expert schatting kan worden gevalideerd door te onderzoeken onder praktische of experimentele omstandigheden of er sprake is van ongerief of dehydratatie bij vleeskuikenouderdieren die beperkt water verstrekt krijgen. 


\section{$1 \quad$ Inleiding}

Binnen de geldende wetgeving (Wet Dieren, 2014 en Besluit houders van dieren, 2014), die onder andere van toepassing is op de vleeskuikensector (opfok vleeskuikenouderdieren, productiefase vleeskuikenouderdieren, vleeskuikens), wordt voorgeschreven voor alle gehouden dieren (zoogdieren, reptielen, amfibieën, vogels en vissen):

'Diegene die een dier houdt, draagt er zorg voor dat een dier toegang heeft tot een toereikende hoeveelheid water van passende kwaliteit of dat een dier op een andere wijze aan zijn behoefte aan water kan voldoen.'

De memorie van toelichting op de Wet Dieren geeft de context waarbinnen de invulling van deze regel nadere invulling moet krijgen door het handelen van overheid en burgers:

'Dieren zijn vrij van:

a. Dorst, honger en onjuiste voeding'

Voor de verschillende diersoorten zijn eisen gesteld aan de watervoorziening die niet eenduidig benoemd zijn: 'permanente waterverstrekking', 'toereikende hoeveelheid', en 'toegang tot' komen alle voor. Het zijn open geformuleerde normen, die voor NVWA inspecteurs moeilijk te handhaven zijn. In de vleeskuikensector en vlees vermeerderingssector wordt aan dit voorschrift gedurende de boerderijfase op verschillende wijze invulling gegeven, variërend van enige vorm van waterrestrictie tot het onbeperkt verstrekken van drinkwater.

Water is een essentiële voedingsstof, die vaak over het hoofd wordt gezien. Dieren kunnen langer overleven zonder voedsel dan zonder water. Water is betrokken bij elk aspect van het metabolisme van dieren. Het speelt een belangrijke rol in het reguleren van lichaamstemperatuur, verteren van voedsel en het elimineren van afvalstoffen. Tijdens periodes van hoge temperaturen, kan het waterverbruik verdubbelen of verviervoudigen ten opzichte van het verbruik onder thermoneutrale condities. Om gezond te blijven is water van voldoende kwaliteit en kwantiteit dus van groot belang voor kippen (SCAHAW, 2000; Bestman, et al., 2011; Van der Hoeven-Hangoor, 2014; Vanderhasselt, 2013).

Bij de NVWA is tegen de achtergrond hiervan de vraag gerezen of en zo ja welke risico's de diverse vormen van waterverstrekking in de huidige houderij van vleeskuikens en vleeskuikenouderdieren (opfok- en productiefase) met zich mee brengen ten aanzien van dierenwelzijn, zowel voor het vleeskuiken als de vleeskuikenouderdieren.

\section{$1.1 \quad$ Doelstelling}

Het doel van dit rapport is het beschrijven van de diverse vormen van waterverstrekking in de huidige praktijk van de houderij van vleeskuikens en vleeskuikenouderdieren (opfok- en productiefase) in Nederland, en aangeven of de diverse vormen van waterverstrekking mogelijk risico's met zich meebrengen in termen van dierenwelzijn (inclusief diergezondheid). De onderbouwing hiervoor vindt plaats door middel van een literatuurstudie en een beperkte risico inventarisatie door experts, aangevuld met een inventarisatie onder stakeholders (personen die in Nederland werkzaam zijn in de vleeskuiken- en vermeerderingssector en gezamenlijk een goed beeld hebben van de huidige praktijk op vleeskuikenbedrijven en opfok- en productiebedrijven van vleeskuikenouderdieren). 


\subsection{Opbouw van het rapport}

Allereerst worden beschreven hoe het literatuuronderzoek en de consultatie van experts en stakeholders is uitgevoerd. Daarna worden achtereenvolgens de volgende vragen behandeld:

1. Hoe nemen kippen bij voorkeur water op (literatuuronderzoek);

2. De fysiologie van de waterhuishouding bij kippen (literatuuronderzoek);

3. Waterverstrekking, de praktijk (resultaten stakeholderconsultatie) en effect van diverse methoden van waterverstrekking op het welzijn van vleeskuikens en vleeskuikenouderdieren (literatuuronderzoek en expertopinie);

4. Factoren van invloed op de wateropname van vleeskuikens en vleeskuikenouderdieren (literatuuronderzoek en resultaten stakeholderconsultatie).

De resultaten worden bediscussieerd in termen van het risico dat bepaalde vormen van waterverstrekking, wateronthouding of waterbeperking mogelijk met zich mee brengen voor het welzijn van vleeskuikens en vleeskuikenouderdieren. Vervolgens wordt besproken, indien er sprake is van een risico op dierwelzijn, welke maatregelen genomen kunnen worden om het risico te beperken en welke voor- of nadelen deze maatregelen hebben.

Als laatste worden de kennislacunes aangegeven en worden aanbevelingen voor verder onderzoek gedaan. 


\section{Methoden}

\section{$2.1 \quad$ Literatuuronderzoek}

Voor het literatuuronderzoek is gebruik gemaakt van de zoekmachines 'Scopus' en 'Web of Science'. De volgende zoektermen zijn hiervoor gehanteerd: dehydration AND (broiler* or poult* or chick*), of (water intake OR water supply OR water requirement*) and (broiler* OR poult* OR chick*); water*; water intake; water consumption AND (broiler* or poult* or chick*) (bij broiler* wordt meteen gezocht in de literatuur betreffende broiler breeders). Daarnaast zijn bovengenoemde zoektermen gecombineerd met de volgende termen (d.m.v. 'AND'): thirst; light*; light schedule; light intensity; daylight/day light; food composition; food*; electrolyte balance; trace minerals; NSP content; raw fibre; litter type; litter quality; drinker type; heat stress, water contamination; ventilation; humidity; dust; locomotion; gait; mobility; respiratory disease; stocking density.

In aanvulling op de literatuur, die beschikbaar is via de databases van wetenschappelijke artikelen is gezocht binnen Wageningen Livestock Research rapporten ('grijze literatuur'), is via Google gezocht op het internet naar grijze literatuur met behulp van bovengenoemde zoektermen, en is aan buitenlandse onderzoekers gevraagd om niet gepubliceerde informatie of grijze literatuur aan te leveren met betrekking tot het onderwerp (zie 2.3). De gebruikte grijze literatuur staat weergegeven in de referentielijst. Ook is gebruik gemaakt van cross referenties in gevonden papers.

\subsection{Risico inventarisatie}

Voor de diverse methoden van waterverstrekking aan vleeskuikens en vleeskuikenouderdieren in Nederland is een beperkte risico inventarisatie uitgevoerd door het bevragen van twee experts (Wageningen Livestock Research onderzoekers) per diercategorie. Deze experts werden geselecteerd op basis van hun kennis van de diersoort en het vakgebied. Aan de experts werd gevraagd om per diercategorie de ernst en duur van het ongerief als gevolg van de methode van waterverstrekking in te schatten. Hierbij is dezelfde methodiek gehanteerd als in Visser et al. (2015). De ernst is beoordeeld op een schaal van 1 tot 5 (welzijnsaantasting afwezig (1) tot zeer ernstige welzijnsaantasting (5)), de duur op een schaal van 1-3 (kort-middel-lang, zie voor een beschrijving Visser et al. (2015)). De combinatie van deze scores leidde tot een score voor impact op een schaal van 1-7 (geen impact op het dier tot veel impact op het dier). Zie voor een toelichting op de impact score Visser et al. (2015).

\subsection{Stakeholder consultatie}

Omdat op voorhand werd verwacht dat een aantal vragen niet op basis van literatuuronderzoek te beantwoorden zijn, is in aanvulling op het literatuuronderzoek gekozen voor een consultatie van stakeholders. Met stakeholders worden bedoeld personen die in Nederland werkzaam zijn in de pluimveevleessector, hetzij als praktiserend dierenarts, als specialist bij een fokkerijorganisatie of als specialist bij een veevoerbedrijf. Voor iedere deelsector (vleeskuikens of vleeskuikenouderdieren) is gekozen voor vertegenwoordigers uit de verschillende geledingen, met een ruime ervaring in de pluimveevleessector en met ervaring bij vleeskuikens en vleeskuikenouderdieren van een trager groeiend of een regulier vleeskuikenras en de daarbij horende houderij- en managementsystemen. Voor de vleeskuikens zijn vijf specialisten geraadpleegd en voor de vleeskuikenouderdieren vier specialisten, deze zijn nader gespecificeerd in bijlage 1 . Bij de stakeholderconsultatie is gekozen voor de volgende aanpak: 
1. Er is een vragenlijst opgesteld door de onderzoekers;

2. Stakeholders zijn telefonisch benaderd voor deelname, in het gesprek werd het project kort toegelicht;

3. Stakeholders hebben de vragenlijst per e-mail toegestuurd gekregen;

4. Stakeholders hebben de vragenlijst ingevuld, ofwel in een persoonlijk of telefonisch gesprek met de onderzoeker of alleen, waarna de vragen telefonisch zijn doorgesproken met de onderzoeker;

5. Stakeholders hebben de antwoorden ter inzage gekregen en de mogelijkheid gehad hierop te reageren;

6. Stakeholders hebben de concepttekst van de rapportage, die betrekking had op de stakeholderconsultatie, kunnen becommentariëren.

Bijlage 2 geeft de vragenlijst weer die aan de stakeholders is voorgelegd.

\subsection{Internationale experts}

Omdat op voorhand werd verwacht dat een aantal vragen niet op basis van literatuuronderzoek te beantwoorden zijn, is er ook een e-mail consultatie verzonden naar internationale experts (onderzoekers) op het gebied van welzijn en management van pluimvee. Daarvoor is gebruik gemaakt van de verzendlijst van de Werkgroep 9 (Welfare and Management) van de World's Poultry Science Association. Deze bestaat uit 34 personen uit geheel Europa. Deze verzendlijst is aangevuld met prof. F.A.M. Tuyttens, ILVO Gent, België. Binnen zijn onderzoeksgroep is een aantal jaren geleden gewerkt aan het onderwerp 'meten van dorst'. Aan allen is specifiek de vraag gesteld informatie aan te leveren die niet beschikbaar was via de databases met wetenschappelijke literatuur, dus niet-gepubliceerde en grijze literatuur, met betrekking tot onderzoeksvragen 1 tot en met 5. Deze oproep heeft een beperkte hoeveelheid grijze literatuur opgeleverd, die waar relevant is meegenomen in de resultaten van het literatuuronderzoek. 


\section{$3 \quad$ Wateropnamegedrag}

Kippen gebruiken zwaartekracht om te drinken en water naar beneden te laten stromen in de slokdarm. Ze moeten water in hun snavel scheppen en dan hun kop naar achteren kantelen. Bij het drinken vinden drie opeenvolgende gedragsfasen plaats (Heidweiller, et al., 1992), zie ook Figuur 3.1: (1) wanneer de snavel wordt ondergedompeld, komt water vanuit de waterbak in de snavelholte. Fijn op elkaar afgestemde cyclische bewegingen van snavel, tong en strottenhoofd (capillaire werking, persen en zuigen) vervoeren water door de snavelholte, (2) bij het opheffen van de kop wordt de tong omhoog gebracht en het strottenhoofd omlaag, waardoor het water in de keelholte gehouden wordt (de zwaartekracht en de centrifugale krachten als gevolg van de opwaartse swing van het hoofd worden gecompenseerd), (3) tijdens de snavelhoog (kop omhoog) fase wordt het water door de zwaartekracht naar de slokdarm getransporteerd. Daarbij worden kleine druppels water actief naar beneden geduwd en geperst door tong- en strottenhoofdbewegingen/slikken. De meeste elementen van dit drinkpatroon blijken zo flexibel te zijn dat een kip de bewegingspatronen van de kaken, tong, het strottenhoofd, en het hoofd kan aanpassen, bijvoorbeeld wanneer het dier te maken heeft met suboptimale omstandigheden, zoals drinknippels (Houldcroft, et al., 2008) of is gesnavelkapt (Heidweiller et al., 1992). Het mechanisme om water te transporteren van de keelholte naar de slokdarm tijdens de tip up fase (slikken) is al aanwezig op de leeftijd van 1 week en verandert niet tijdens het opgroeien (Heidweiller and Zweers, 1992). Daarentegen veranderen in de eerste 4 levensweken elementen uit de onderdompelingsfase aanzienlijk, van pikken naar water bij eendagskuikens tot gebruik maken van persen, capillaire werking en zuigen, met het opnemen van grotere hoeveelheden water, bij 4 weken oude kuikens (Heidweiller, Vanloon and Zweers, 1992). Details van het drinkgedrag van vleeskuikens (snavelhoek en afstand tot de drinker) laten systematische veranderingen zien vanaf het uitkomen tot een leeftijd van 5 weken (Ross and Hurnik, 1983). Daarnaast blijken de dieren steeds minder vaak naar de drinker te gaan, waar per drinkbeurt een groter volume wordt geconsumeerd. Deze informatie is van belang voor de inrichting van drinksystemen die zo goed mogelijk tegemoet komen aan het natuurlijke drinkgedrag van vleeskuikens (Ross and Hurnik, 1983). Naast de individuele ontwikkeling is er ook een sociale ontwikkeling van drinkgedrag. Drinkgedrag blijkt afhankelijk van wel of niet drinkgedrag van soortgenoten in de nabijheid, sociale facilitatie genoemd (Franchina, et al., 1986; Hoppitt and Laland, 2008).

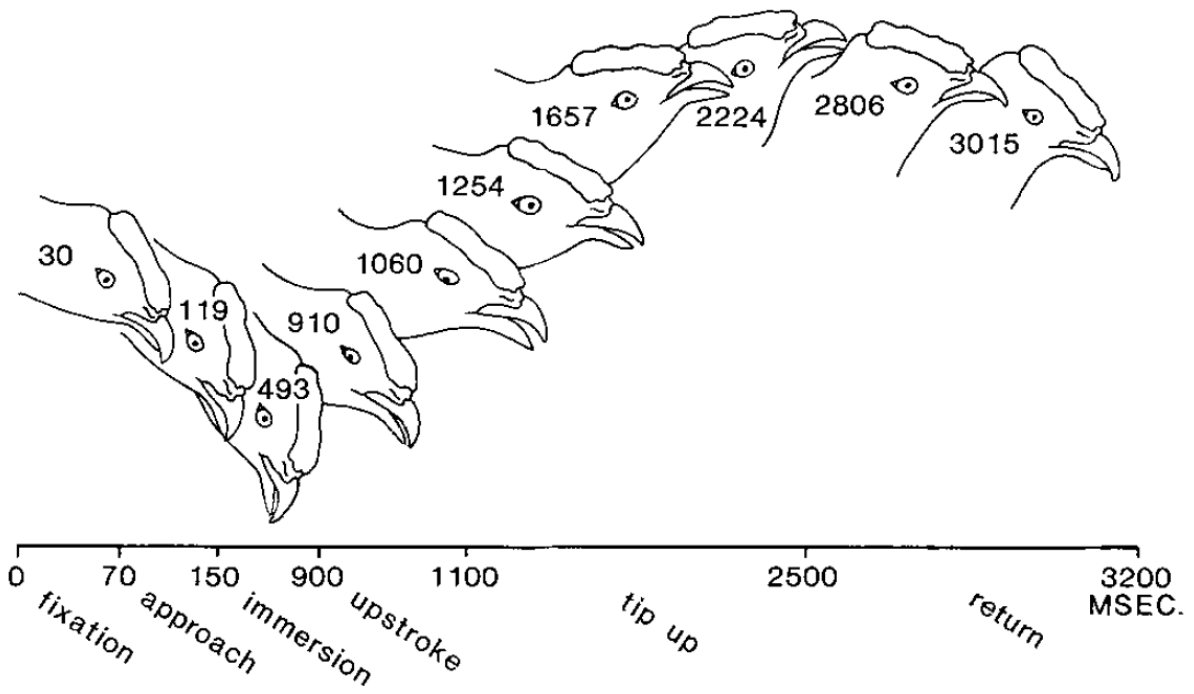

Figuur 3.1 Schematische weergave van een complete drinkcyclus bij de kip (Heidweiller et al., 1992). Elke drinkcyclus wordt onderverdeeld in zes fasen, die zijn aangegeven langs de tijdas in milliseconden. Fixatie (1), benadering (2), onderdompeling (3), de stijgfase (4), snavel omhoog (5) en vervolgens de terugbeweging (6). Drinken bestaat extern zichtbaar uit een reeks van dergelijke zich herhalende cycli, waarbij intern ook typische kaak-, tong-en keelholtebewegingen optreden. 
Om te leren drinken beschikken kuikens over de aangeboren reactie om te pikken naar alles wat glimt, in de natuur zijn dit plassen, dauwdruppels e.d. Als een kuiken een ander kuiken drinkbewegingen ziet maken, rent het kuiken er snel heen en kopieert dit gedrag (sociale facilitatie) (Bäumer, 1955; Bestman en Keppler, 2005). Pas uitgekomen kuikens kunnen moeite hebben om bij het water te komen of om water op te nemen. Soortgelijke problemen kunnen ook optreden bij oudere dieren, wanneer ze worden verplaatst naar een nieuwe omgeving, waar de drinkmogelijkheden anders zijn (bijvoorbeeld van een open drinkwatersysteem, zoals een ronddrinker of drinkcups naar een gesloten drinkwatersysteem zoals drinknippels). Als het drinken niet op een natuurlijk manier kan, is veelal operant conditioneren vereist om bijvoorbeeld een drinknippel te activeren, en zullen de kippen of door spontane 'trial and error' (leren) of door de veehouder geholpen moeten worden, bijvoorbeeld door het dippen van de snavel in het water of bedienen van een drinknippel (Ag_Guide, 2010), of door bijvoorbeeld met een borstel langs de drinklijn te strijken zodat er een druppel aan de nippel komt te hangen waardoor de kip wordt getriggerd (Van Harn, pers. med.). In de praktijk wordt dit voorkomen door de drinksystemen in de opfokperiode en productieperiode op elkaar af te stemmen. Daarnaast worden vaak adviezen voor waterverstrekking aan vleeskuikens vaak gegeven door praktijkspecialisten (Tabler et al., 2012) en NGO's met betrekking tot dierenwelzijn (Farming, 2013; Compendium, 2013 update).

Er zijn verschillende typen drinkers voor kippen: drinknippels, ronddrinkers en drinkcups of cup drinkers. Nippeldrinkers laten het normale drinkgedrag van kippen niet toe, omdat de vleeskuikens naar boven moeten pikken om water te krijgen; dit in tegenstelling tot ronddrinkers en drinkcups waar kippen op de voor hen normale manier kunnen drinken (Houldcroft et al., 2008). De effecten van nippeldrinkers en ronddrinkers op vleeskuikens zijn onderzocht in verschillende vergelijkende tests en de conclusies waren: 1) wanneer drinknippels, ronddrinkers en open schalen met water worden aangeboden, drinken vleeskuikens meer water uit de ronddrinkers en de schalen dan uit de nippels, 2) vleeskuikens vertonen de stereotiepe 'schepbeweging' altijd wanneer ze drinken uit ronddrinkers van verschillende hoogten, 3) bij het aanbieden van drinknippels op verschillende hoogtes vertonen vleeskuikens een sterke voorkeur om te drinken uit drinknippels die relatief laag hangen, 4) wanneer gekozen kan worden tussen ronddrinkers en drinknippels die hangen op dezelfde hoogte, zijn er geen verschillen in voorkeur voor het type drinker, maar is er een voorkeur om water op te nemen uit drinkers die laag hangen. Wanneer beiden hoog hangen heeft het kuiken de voorkeur voor de pikbeweging naar de nippel boven de (lastige) schepbeweging uit een te hoge ronddrinker. De hoogte van de drinker is klaarblijkelijk belangrijker dan de mogelijkheid om de schepbeweging te kunnen maken (Houldcroft et al., 2008). Houldcroft et al. (2008) suggereren dat zwaardere vleeskuikens moeite kunnen hebben om de balans te vinden bij de strekbeweging om te drinken uit een hoge nippel, wat de voorkeur voor een lage drinker kan verklaren.

Meestal zullen kippen langer drinken bij een drinknippelsysteem dan bij ronddrinkers (zie de betreffende paragrafen onder factoren). Dat komt omdat de kip meer inspanning moet verrichten (vaker moet pikken naar de nippel) om eenzelfde hoeveelheid water op te nemen in vergelijking met een ronddrinker of drinkcup. Een van de nadelen van ronddrinkers is dat er meer water vermorst wordt, wat de strooiselkwaliteit negatief kan beïnvloeden (Vanderhasselt, 2013). Vleeskuikens worden meestal grootgebracht met drinknippels; de drinknippellijn wordt geleidelijk verhoogd als de kippen groeien (zie bijvoorbeeld The University of Tennessee Agricultural Extension Service, 1994). Bij vleeskuikenouderdieren worden meestal drinknippels, maar ook nog ronddrinkers gebruikt en tijdens de opfokperiode soms een combinatie van beide systemen.

Drinkgedrag is sterk verbonden met foerageergedrag gedurende de dag (Lott, et al., 2003; Murphy and Preston, 1988). De afwisseling tussen eet- en drinkgedrag bij vleeskuikens is slechts spaarzaam bestudeerd (Murphy and Preston, 1988; Puma et al., 2001; Hoppitt and Laland, 2008). Murphy and Preston (1988) lieten zien bij vleeskuikens dat drink 'bouts' (periode van aaneengesloten gedrag) altijd korter duurden dan voeropname 'bouts' en dat de meeste drink 'bouts' tussen 19 en 43 dagen leeftijd korter dan één minuut duurden. De duur van een drink 'bout' nam toe wanneer er meer kuikens aan het drinken waren en duurde bij verstoring korter dan wanneer een kuiken vrijwillig stopte met drinken. Verder toonden ze aan dat het aantal keren dat het kuiken met de snavel in het water zat positief gerelateerd was aan de tijd dat ze bij de drinker stonden (in deze proef werden 
ronddrinkers gebruikt). Omdat dit relatief oude literatuur is en meer recente gegevens hierover niet zijn gevonden, zijn deze resultaten mogelijk niet representatief voor het huidige vleeskuiken.

Richtlijnen geven aan dat één drinknippel water moet bieden aan 10 tot 12 vleeskuikens (Tabler, 2003). Eén drink cup moet water bieden aan 28 vleeskuikens en voor een ronddrinker wordt een verhouding van 1 drinker:100 kuikens aangehouden (Welfare Quality, 2009), maar deze normen zijn mede afhankelijk van het type nippel en dan met name de wateropbrengst of de grootte of diameter van de cup of ronddrinker (Van Harn, pers. med.). In de milieukeur normen voor vleeskuikens worden iets ruimere richtlijnen aangehouden, maximaal 14 vleeskuikens per nippel of 45 vleeskuikens per drink cup (SMK, 2016). Een wetenschappelijke onderbouwing voor deze getallen is niet gevonden. Naast een voldoende aantal drinknippels is een voldoende waterstroom vanuit de drinknippels van belang. De keuze voor het type drinker hangt samen met de waterconsumptie, maar ook aan met waterverspilling en de gevolgen van deze verspilling zoals contactdermatitis (De Jong et al., 2014; Eichner et al., 2007; Elson, 2010; Elson, 1989; Van Harn et al., 2014a; De Jong et al., 2014; De Jong and Van Harn, 2016; De Jong et al., 2015; Mcilroy et al., 1987; Tullo et al., 2015), borstirritatie en borstblaren (Senaratna et al., 2016; Tullo et al., 2015). Een systeem bestaande uit drinknippels met opvangschoteltjes is waarschijnlijk de meest efficiënte manier van het verminderen van waterverspilling (Hocking et al., 2004; Weeks and Butterworth, 2004); deze worden momenteel op een groot deel van de vleeskuikenbedrijven toegepast om nat strooisel en de negatieve gevolgen daarvan te voorkomen. 


\section{De fysiologie van de waterhuishouding bij kippen}

Water is één van de belangrijkste bestanddelen van het lichaam van een dier en dus ook van pluimvee. Het lichaam van een volwassen kip bestaat voor ongeveer $60 \%$ uit water, waarvan ongeveer tweederde intracellulair water is en één derde extracellulair water (Houpt, 2004). De laatst genoemde één derde bestaat weer voor $75 \%$ uit interstitieel water en de overige $25 \%$ uit plasma. Dit laatste is van groot belang, omdat een groot aantal parameters die bepaald kunnen worden om het niveau van dehydratie te bepalen, gedaan wordt in het bloed of in het plasma.

Het handhaven van het waterevenwicht (osmoregulatie) is van groot belang voor het welzijn van het dier. In geval deze balans niet voldoende gehandhaafd kan worden, kan dorst ontstaan. De waterbalans wordt bepaald door de wateropname en het waterverlies en deze twee zijn sterk aan elkaar gerelateerd. Om dus een goede waterbalans te handhaven, moet aandacht besteed worden aan twee onderdelen: 1) wateropname en 2) waterverlies (Leeson et al., 1996; Belay and Teeter, 1993).

Wateropname: Wateropname bestaat uit drie onderdelen: 1) opname via het drinkwater (65-80\%); 2) metabool water dat tijdens het metabolisme van nutriënten vrijkomt $(15-25 \%) ; 3)$ water beschikbaar via de opname van voeding $(<10 \%)$.

Waterverlies: Water gaat verloren op drie verschillende manier: 1) water wordt vastgelegd in het lichaam, met name in jonge groeiende dieren; 2) water wordt uitgescheiden via excreta; 3) water gaat verloren via verdamping.

In dit hoofdstuk wordt besproken uit welke onderdelen de waterbalans in het lichaam bestaat, welke factoren van belang zijn voor de waterbalans en hoe de waterstatus in het dier gemeten kan worden. De regulatie van de waterbalans op celniveau en in de nieren zal niet in detail besproken worden, deze detail kennis is niet relevant voor dit rapport.

\subsection{Wateropname}

De eerste categorie van wateropname is de drinkwateropname. Drinkwateropname wordt beïnvloed door veel verschillende factoren. De belangrijkste categorieën, die van invloed zijn op de wateropname zijn samengevat in Tabel 4.1 (Van der Hoeven-Hangoor, 2014). Uit deze tabel blijkt dat er vele factoren van invloed zijn op de wateropname, maar niet alle factoren hebben even veel invloed op de wateropname. De belangrijkste factoren zijn: voeropname, omgevingstemperatuur en relatieve luchtvochtigheid. Omdat de vraag naar de fysiologie van de waterhuishouding bij kippen thermoneutrale condities als uitgangspunt heeft genomen zal niet ingegaan worden op de invloed van de omgevingstemperatuur en de relatieve luchtvochtigheid bij de beschrijving van de fysiologie. Wateropname is dus onder thermoneutrale omstandigheden sterk gerelateerd aan de voeropname (Lott et al., 2003). De verhouding water:voer bij vleeskuikens is over het algemeen tussen de 1.6 en 2.0 (Williams, 1996; Lott et al., 2003; Watkins et al., 2009; Collett, 2012). 
Tabel 4.1 Factoren van invloed op de wateropname van vleeskuikens (Van der Hoeven-Hangoor, 2014).

\begin{tabular}{|c|c|}
\hline Categorie & Factoren \\
\hline Dierfactoren & $\begin{array}{ll}\text { - } & \text { genetische achtergrond } \\
\text { - } & \text { geslacht } \\
\text { - } & \text { leeftijd } \\
\text { - } & \text { lichaamsgewicht } \\
\text { - } & \text { gezondheidsstatus } \\
\text { - } & \text { lichaamstemperatuurregeling } \\
\text { - } & \text { metabool water productie }\end{array}$ \\
\hline Waterkwaliteit factoren & $\begin{array}{ll}\text { - } & \text { hardheid } \\
\text { - } & \text { nitraatconcentratie } \\
\text { - } & \text { zware metalenconcentratie } \\
\text { - } & \text { bacteriële contaminatie }\end{array}$ \\
\hline Voedingsfactoren & $\begin{array}{ll}\text { - } & \text { nutriëntenconcentratie } \\
\text { - } & \text { bepaalde ingrediënten } \\
\text { - } & \text { voeropname } \\
\text { - } & \text { voervorm } \\
\text { - } & \text { drogcotoxine contaminatie } \\
\text { - } & \text { coccidiostatica } \\
\end{array}$ \\
\hline huisvestings- en omgevingsfactoren & $\begin{array}{ll}\text { - } & \text { watertemperatuur } \\
\text { - } & \text { waterdruk } \\
\text { - } & \text { kwaterstroomsnelheid } \\
\text { - } & \text { drinker type } \\
\text { - } & \text { drinker hoogte } \\
\text { - } & \text { verspilling door kuikens } \\
\text { - } & \text { lekkage } \\
\text { - } & \text { staltemperatuur } \\
\text { - } & \text { luchtsnelheid } \\
\text { - } & \text { relatieve luchtvochtigheid }\end{array}$ \\
\hline
\end{tabular}

Water- en voeropname wordt gereguleerd door de laterale en ventromediale hypothalamus (Banghbanzadeh et al., 2010). Bij pluimvee wordt het water onder natuurlijke omstandigheden opgenomen door middel van het "scheppen" van water (Houldcroft et al., 2008), zie voor een uitgebreide beschrijving Hoofdstuk 3.

De tweede bron van wateropname is het metabool water. Metabool water is een bijproduct van metabolisme van nutriënten. Afhankelijk van de samenstelling van het voer komt er meer of minder metabool water beschikbaar. Bij de oxidatie van vet, koolhydraten en eiwit is dit respectievelijk 1.18, 0.6 en 0.5 gram metabool water per gram van het specifieke nutriënt (Kerstens, 1964). Een alternatieve berekeningsmethode om de hoeveelheid metabool water te bepalen is uit te gaan van energiewaarden. Per $\mathrm{kJ}$ aan voerenergie wordt ongeveer $0.032 \mathrm{~g}$ metabool water geproduceerd (Kersten, 1964). Gemiddeld kan uitgegaan worden dat 15 tot $25 \%$ van de totale wateropname afkomstig is van metabool water.

De derde bron van wateropname is het water in het voer. Uitgaande van commercieel beschikbaar pluimveevoer (meel of pellet), zal er ongeveer $10 \%$ water in aanwezig zijn. Echter wanneer gebruikt gemaakt wordt van vochtige voeders dan kan het percentage aan wateropname via het voer fors toenemen (Syafwan, 2012). In Nederland wordt echter nauwelijks gebruik gemaakt van vochtige voeders voor vleeskuikens of vleeskuikenouderdieren en daarom is het minder van belang om hier rekening mee te houden.

\subsection{Waterverlies}

De eerste bron van waterverlies bij pluimvee is uitscheiding via de excreta. Omdat kippen geen urineblaas hebben wordt de urine uitgescheiden in de vorm van urinezuur in de cloaca, gezamenlijk met de feces. Daarom worden feces en urine als geheel behandeld en als excreta benoemd. In verse excreta varieert het watergehalte tussen 60 en $80 \%$ (Leeson et al., 1976; Henuk and Dingle, 2003). Dit vochtpercentage hangt af van de wateropname, waarbij een hogere wateropname zorgt voor een hoger vochtpercentage in de excreta. Onder thermoneutrale condities vindt ongeveer $54 \%$ van de wateruitscheiding plaats via de urine en de andere $46 \%$ via de feces (Belay and Teeter, 1993). Urineproductie wordt gereguleerd door de nieren. De nieren kunnen 70 tot $99 \%$ van het gefilterde watervolume reabsorberen, met als gevolg dat de urine meer of minder geconcentreerd is (Goldstein 
and Skadhauge, 2000). Daarnaast reguleren de nieren ook de reabsorptie van natrium ( $\mathrm{Na}$ ). $\mathrm{Na}$ de excretie van urine in de cloaca, kan urine teruggevoerd worden in het coprodeum, het colon en de caeca. Dit gebeurt middels terugwerkende peristaltische bewegingen. In het coprodeum, het colon en de caeca kan opnieuw een aanzienlijke hoeveelheid water en Na gereabsorbeerd worden (Thomas, 1982, Goldstein and Skadhauge, 2000). Onder normale omstandigheden kan in een kuiken tot 36\% van het water en $75 \%$ van de $\mathrm{Na}$ uit de urine gereabsorbeerd worden in het coprodeum, het colon en de caeca (Thomas, 1982). Details over de werkingsmechanismen van de nieren en van de betrokken darmsegmenten worden hier niet uitgewerkt, zie hiervoor reviews van Goldstein and Skadhauge (2000), Laverty and Skadhauge (2008), Svihus et al. (2013) en Braun (2015).

De tweede bron van waterverlies is evaporatie. Evaporatie vindt plaats via de huid van het kuiken of via de ademhaling. Omdat kuikens zeer beperkt zweetklieren hebben, is de evaporatie via de huid ook zeer beperkt. Dit betekent dat het grootste deel van de evaporatie plaatsvindt via de ademhaling en de mate van evaporatie samenhangt met de ademhalingsfrequentie. Als de ademhalingsfrequentie omhoog gaat, zal ook het waterverlies via evaporatie verhoogd worden. De waterverliezen via evaporatie zijn aanzienlijk groter dan de waterverliezen via de excreta. Leesons (1976) berekende dat de waterverliezen via verdamping stegen met de leeftijd van ongeveer 35\% in week 1 tot ongeveer $70 \%$ van al het waterverlies in week 6 . Hiermee is dus evaporatie de belangrijkste bron van waterverlies bij kuikens, ook tijdens thermoneutrale omstandigheden. Evaporatie gebruikt het kuiken om de lichaamstemperatuur niet te hoog te laten worden. De hogere ademhalingsfrequentie heeft dus als doel meer warmte af te voeren door een hogere verdamping van vocht (zie ook par. 5.4.7).

De derde bron van waterverlies is het vastleggen van water in het lichaam. Wanneer een dier groeit zal het ook water vastleggen. Dit komt doordat bij met name eiwitaanzet ook water wordt gebonden. Dit betekent dat een jong groeiend dier relatief meer water in het lichaam heeft dan een volwassen dier. Gemiddeld bestaat een vleeskuiken voor meer dan $70 \%$ uit water, terwijl het watergehalte bij een vleeskuikenouderdier ongeveer $60 \%$ is (Houpt, 2004).

\subsection{Hoe kan de waterstatus gemeten worden}

Het bepalen van de waterstatus van een vleeskuiken of vleeskuikenmoederdier kan gedaan worden op verschillende niveaus. Deze niveaus zijn: het hele kuiken, de excreta en het bloed. Deze zullen hieronder besproken worden.

\subsubsection{Het hele kuiken}

Als gekeken wordt naar het hele kuiken zijn verschillende metingen mogelijk om de waterstatus te bepalen. Dit zijn:

- Lichaamstemperatuur. De relatie tussen de periode van wateronthouding en lichaamstemperatuur is nauwelijks onderzocht. Duidelijk is dat een hogere temperatuur, waarbij meer vochtverlies optreedt, resulteert in een hogere lichaamstemperatuur (e.g. Syafwan, 2012). Het is echter niet duidelijk hoeveel water een kuiken kan verliezen voordat er sprake is van een stijging in lichaamstemperatuur. In leghennen liet Arad et al. (1985) zien dat na 48 uur zonder water bij een normale omgevingstemperatuur de lichaamstemperatuur niet veranderd was. Bij een hoge omgevingstemperatuur liep de lichaamstemperatuur in gedehydrateerde kippen verder op dan in niet-gedehydrateerde kippen.

- Lichaamsgewicht. Gerelateerd met het vorige punt is de relatie tussen wateronthouding en lichaamsgewicht. Ook hier is nauwelijks onderzoek naar gedaan. Arad et al. (1985) liet zien dat in leghennen het lichaamsgewicht met 7.9 en $13.4 \%$ verlaagd was na een periode van wateronthouding van respectievelijk 24 en 48 uur. Knowles et al. (1995) lieten een 10\% gewichtsverlies zien tijdens een 24 uur durende periode van water- en voedselonthouding. Een punt van aandacht bij lichaamsgewicht is dat een kuiken ook gewicht verliest via de feces en dat een dier geen voer moet opnemen in de periode waarin effecten van wateronthouding bepaald worden vanwege mogelijke opname van water via de voeding. 
- Wateropname na een periode van wateronthouding. Het bepalen van de wateropname van kuikens na een periode van wateronthouding kan een goede indicatie geven van de mate van dorst bij kuikens (Sprenger et al., 2009; Vanderhasselt et al., 2010, 2014). Uit deze studies bleek dat de kuikens meer water opnamen na een langere periode van wateronthouding, vooral als ze bekend waren met de gebruikte type drinker. Deze verhoogde wateropname vond vooral plaats in de eerste 30 minuten na verstrekking van het drinkwater (zie figuur 4.1).

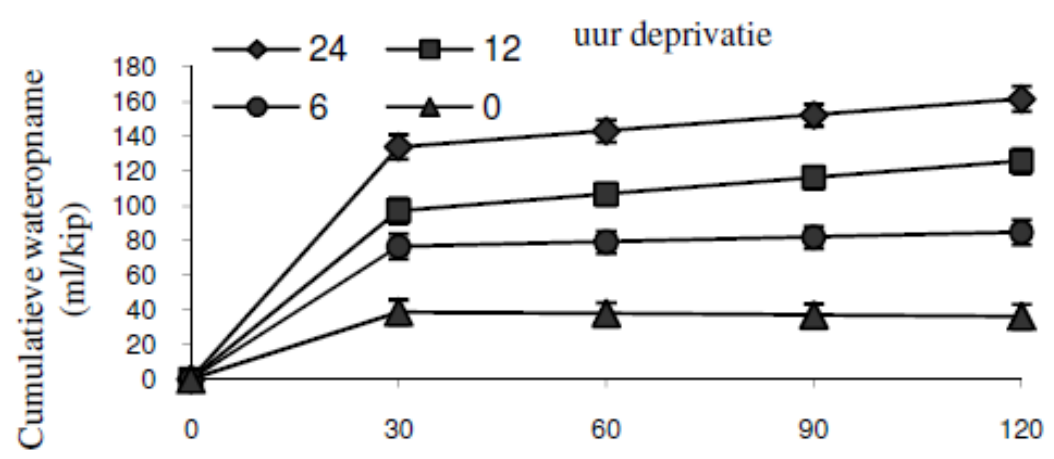

Tijd (min)

Figuur 4.1. Cumulatieve wateropname \pm SEM gedurende 120 minuten na 0, 6, 12 en 24 uur water deprivatie, voor kippen die vertrouwd waren met het type drinker (Vanderhasselt et al., 2010).

\subsubsection{De excreta}

In het geval van dehydratatie zijn kuikens in staat om het waterverlies via de excreta te verminderen. Dit wordt gedaan door een hogere reabsorptie van water in de nieren en in de darm, waardoor de mest en urine minder water bevatten (Laverty and Skadhauge, 1999). Verzameling van excreta kan daarom een methode zijn om dehydratatie vast te stellen. Wel is dan belangrijk om goede referentiewaarden te hebben en bijvoorbeeld het verloop in de tijd vast te stellen voor b.v. 48 uur.

\subsubsection{Bloedwaarden}

In het bloed zijn vele variabelen die gerelateerd zijn aan dehydratatie. Hieronder zullen de verschillende variabelen kort besproken worden, dit zijn: osmolaliteit, inclusief gerelateerde mineralen; hematologische variabelen; hormonen; bloedeiwitten en leverenzymen. Bij alle bloedparameters moet aangegeven worden dat bij dehydratatie er nog steeds vochtverlies optreedt, waardoor in het bloed de concentraties van veel stoffen dikwijls oplopen doordat het bloed geconcentreerder wordt. Daarnaast zijn de verschillen tussen individuele kuikens wat betreft bloedwaarden meestal groot en laten studies onderlinge verschillen zien in de reactie van bloedwaarden op dehydratatie.

- Osmolaliteit, inclusief gerelateerde mineralen. Osmolaliteit is de concentratie van osmotisch werkzame stoffen per gram lichaamsvloeistof (bloed). Osmolaliteit wordt bepaald door o.a. mineralen in het bloed, zoals $\mathrm{Na}+, \mathrm{K}+, \mathrm{Cl}$ - en HCO3-. Vele onderzoekingen hebben duidelijk effecten van dehydratatie laten zien op de osmolaliteit en de gerelateerde mineralen. Tijdens wateronthouding neemt de osmolaliteit toe, met name wanneer dehydratie meer dan 24 uur duurt (Knowles et al., 1996; Butterworth et al., 2002; Vanderhasselt et al., 2013), hoewel Saito and Grossmann (1998) al een stijging in osmolaliteit lieten zien na 6 uur dehydratatie. Effecten van dehydratatie op mineralen zijn niet altijd consistent. Over het algemeen neemt het $\mathrm{K}+$ gehalte af tijdens dehydratie, terwijl $\mathrm{Na}+$ toeneemt (Van der Hasselt et al., 2013). Soms wordt geen effect op $\mathrm{Na}+$ gevonden (Saito and Grossmann, 1998). Effecten van dehydratie op Cl-, HCO3- en Ca2+ zijn niet altijd consistent tussen de verschillende studies (Arad et al., 1985; Ikeukwumere and 
Herbert, 2003; Vanderhasselt et al., 2013). Mogelijk heeft dit te maken of gewerkt werd met totale wateronthouding of met waterrestrictie.

- Hematologische variabelen. Tijdens een periode van dehydratie zal een kuiken vocht verliezen, zie paragraaf 1.2. Als gevolg hiervan zal er ook vocht onttrokken worden aan het bloed, waardoor het plasma gehalte zal afnemen. Dit resulteert in een stijging van de bloedviscositeit (Zhou et al., 1998), met name als gevolg van een stijging van het percentage bloedcellen t.o.v. het percentage plasma. Dit wordt uitgedrukt in een stijging van het hematocriet $(\mathrm{Ht})$ of packed cell volume (PCV) gehalte. Deze waarden stijgen bij een langere dehydratatieduur (Knowles et al., 1995; Zhou et al., 1998; Iheukwumere and Herbert, 2003, Vanderhasselt et al., 2013) alhoewel ook wordt aangegeven dat pas na 24 uur waterdeprivatie het hematocrietgehalte significant steeg (Algers and Westin, 2009).

- Hormonen. De belangrijkste hormonen die gerelateerd zijn aan dehydratatie zijn arginine vasotocine (AVT), corticosteron (CORT) en prolactine. AVT is een belangrijk hormoon dat in kuikens de waterbalans reguleert (Saito and Grossmann, 1998). CORT wordt gezien als een algemeen stresshormoon. Van prolactine wordt gesuggereerd betrokken te zijn bij de terugwinning van vocht in de caeca (Arad et al., 1985). Saito and Grossmann (1998) lieten zien dat de AVT concentratie na een 8 uur durende periode van dehydratatie fors gestegen was. Dit werd ook gevonden door Arad et al. (1985). Wat betreft CORT, lieten Knowles et al. (1995) zien dat CORT toenam na een 24 uur durende periode van dehydratatie. Dit terwijl Arad et al. (1985) na een 48 uur periode van wateronthouding geen effect vond op CORT. Wel steeg bij Arad et al. (1985) het prolactine gehalte fors tijdens dehydratie.

- Bloedeiwitten en leverenzymen. Iheukwumere and Herbert (2003) lieten zien dat tijdens een periode van waterrestrictie de gehalten aan totaal eiwit, albumine en globuline in het bloed niet beïnvloed werden. Dit terwijl het ureum gehalte in het bloed daalde en creatinine steeg. Ook bij Vanderhasselt et al. (2013) steeg het creatinine gehalte met een periode van 24 tot 48 uur wateronthouding. Wat betreft leverenzymen, lieten Iheukwumere and Hertbert (2003) geen effect van waterrestrictie zien op de concentraties van alkaline fosfatase, alanine transaminase en aspartaat transaminase.

\subsubsection{Pathologische afwijkingen}

Wanneer er sprake is van langdurige waterdeprivatie en als gevolg daarvan ernstige dehydratie, leidend tot verhoogde mortaliteit, ernstige vermagering en sterk verzwakte dieren in een koppel, kan er sprake zijn van indirecte nieraantasting door vochttekort (bijvoorbeeld bij darminfectie, ernstige kreupelheid of ziekte van Gumboro). Directe nieraantasting kan plaatsvinden door ziektes zoals Infectieuze Bronchitis varianten die nefropathogeen zijn (Pollock, 2006). Dit is bij post-mortem beoordeling door een veterinair vast te stellen aan de hand van een stapeling van urinezuurkristallen in diverse organen, o.a. in nierweefsel, urineleiders, maar ook in gewrichten, op de luchtzakken, op het buikvlies en op ingewanden, bijvoorbeeld op het hartzakje en op het leverkapsel. Dit beeld heet jicht of 'visceral gout'. Ante-mortem is deze diagnose lastig te stellen (Pollock, 2006; Rexhepi et al., 2015). Ook kunnen nierstenen worden waargenomen (urolithasis), dit is ook ante-mortem lastig vast te stellen (Pollock, 2006).

\subsubsection{Praktisch toepasbare indicatoren om de waterstatus van een dier of koppel te bepalen}

Uit bovenstaande blijkt dat er uit de wetenschappelijke literatuur geen valide indicatoren voor dehydratatie bij vleeskuikens of vleeskuikenouderdieren beschikbaar zijn waarmee een inspecteur op een vleeskuiken-, opfok- of vermeerderingsbedrijf eenvoudig en snel uit de voeten kan. De beschikbare indicatoren zijn ofwel relatief tijdrovend ofwel invasief. Wanneer het mogelijk is om bloedonderzoek uit te voeren lijken het hematocrietgehalte of het packed cell volume en plasma $\mathrm{Cl}^{-}$en creatinine valide indicatoren voor dehydratatie bij kippen, die verschillende respons kunnen geven, afhankelijk van de duur van de dehydratatie (Vanderhasselt et al., 2013). Een niet-invasieve en valide test is de cumulatieve wateropname test zoals beschreven door Vanderhasselt et al. (2013) maar deze is praktisch niet gemakkelijk en binnen korte tijd uit te voeren. 
Het 'Welfare Quality ${ }^{\circledR}$ assessment protocol for poultry' (Welfare Quality, 2009) schrijft op dit moment voor dat het aantal vleeskuikens per nippel, cup of ronddrinker in verhouding tot het aanbevolen aantal kuikens per type drinker een indicator is voor afwezigheid van chronische dorst. De werkgroep 'vleeskuikens' van het Welfare Quality Network heeft geadviseerd om deze meting te verwijderen omdat deze niet valide is (De Jong et al., 2015). Vleeskuikens die niet drinken zullen ook niet eten en daarom aan de slachtlijn gescoord kunnen worden onder 'vermagerde kuikens' wat binnen het Welfare Quality ${ }^{\circledR}$ protocol (Welfare Quality, 2009) als indicator voor honger gehanteerd wordt en niet als indicator voor chronische dorst. De werkgroep 'vleeskuikens' maakt daarom ook de kanttekening dat dit een zeer grove indicator is voor chronische dorst en dat het ontwikkelen van een valide en praktisch haalbare indicator voor dorst binnen het Welfare Quality ${ }^{\circledR}$ protocol een hoge prioriteit zou moeten hebben (De Jong et al., 2015). 


\section{Factoren van invloed op de waterconsumptie}

Naast wetenschappelijk literatuur is hier gebruik gemaakt van management gidsen en brochures voor de praktijk (Carter and Sneed, 1987; Tabler, 2003; Jones and Watkins, 2009; Fairchild and Ritz, 2012; Vanderhasselt, 2013; Van der Hoeven-Hangoor, 2014; Vanderhasselt et al., 2014).

De hoeveelheid water verbruikt door kippen wordt beïnvloed door een aantal factoren (Manning et al., 2007a; 2007b), die mogelijk cumulatief of multiplicatief kunnen werken; dergelijke combinaties van factoren zijn echter weinig onderzocht (Castro et al., 2009; Beg et al., 2011). Het is gangbare praktijk om het waterverbruik van de vleeskuikens te controleren door een schatting van het aantal liters per 1000 vleeskuikens per dag (DEFRA, 2002; ACP, 2006). Een stijging of daling van het verwachte waterverbruik kan een indicatie zijn van een gezondheidsprobleem (Butcher, et al., 1999). Te hoge wateropname, verspilling of lekkage kan in combinatie met een te lage afvoer van waterdamp uit de stal leiden tot gezondheids- en welzijnsproblemen, waaronder contact dermatitis, ascites en respiratoire aandoeningen (wanneer de concentratie van ammoniak in de lucht bepaalde niveaus overschrijdt) (Manning et al., 2007a; 2007b). Factoren die het waterverbruik van vleeskuikens en ouderdieren beïnvloeden zijn factoren met betrekking tot het dier, de waterkwaliteit, de voeding en de huisvesting en omgeving (Van der Hoeven-Hangoor, 2014). Deze factoren worden in dit hoofdstuk besproken, aangevuld met een aantal andere factoren die door experts (onderzoekers Wageningen Livestock Research) zijn benoemd (zie additionele factoren en Tabel 9 en 10).

Van een aantal factoren zijn alleen publicaties bekend met betrekking tot vleeskuikens, of alleen met betrekking tot vleeskuikenouderdieren. Daarom wordt in de beschrijving steeds aangegeven welke diercategorie het betreft.

\subsection{Dierfactoren}

$\mathrm{Er}$ is geen wetenschappelijk literatuur beschikbaar over de invloed van geslacht en lichaamsgewicht (anders dan veranderingen met leeftijd) op de waterconsumptie. Soms wordt gezegd dat nietsnavelbehandelde kippen (vleeskuikenouderdieren worden momenteel nog deels snavelbehandeld) meer water vermorsen (Van Emous, pers. med.) maar hierover zijn geen wetenschappelijke publicaties bekend.

\subsubsection{Genetische achtergrond}

Verschillen in waterconsumptie tussen genotypen vleeskuikens zijn in de wetenschappelijke literatuur nauwelijks beschreven. In situaties waar een tekort aan water is, zijn bepaalde genotypen vleeskuikens in het voordeel (Chikumba and Chimonyo, 2014); Naked Neck kippen (NNK) functioneren in dergelijke omstandigheden beter dan Ovambo (OVB) kippen. Pesti et al. (1985) vonden een verschil in waterconsumptie tussen verschillende genotypen vleeskuikens. Uit een andere studie bleken er geen verschillen tussen vleeskuiken genotypen te zijn met betrekking tot compensatie na 24 uur waterdeprivatie (Marks and Brody, 1984). Van Harn (2008) vond in een vergelijkende studie verschillen in de water:voer verhouding tussen verschillende rassen (merken) snelgroeiende vleeskuikens; de Hybro PG+ en G+ hadden een lagere water:voer verhouding in vergelijking met de Ross 308, de Ross 708 en de Cobb 500 (Van Harn, 2008). In een later onderzoek werd gevonden dat de Hubbard Flex een 6\% lagere water:voer verhouding had dan het Ross 308 kuiken, waarbij de wateropname van het Hubbard Flex kuiken 8-10\% lager was dan van het Ross 308 kuiken (Van Harn en De Jong, 2012). Van Horne et al. (2003) vonden een lagere water:voer verhouding bij trager groeiende vleeskuikens in vergelijking met snelgroeiende vleeskuikens. 
Bij vleeskuikenouderdieren leek er geen verschil te zijn in waterconsumptie in de opfokperiode tussen dwergmoederdieren en moederdieren van een snelgroeiend vleeskuikenras (Jones, et al., 2004).

\subsubsection{Leeftijd}

Het absolute waterverbruik bij vleeskuikens stijgt met de leeftijd (en het gewicht), maar neemt af als percentage van het lichaamsgewicht (Pesti et al., 1985). Volgens Pesti et al. (1985) stijgt de waterconsumptie lineair met de leeftijd en kan deze worden geschat voor een kuiken door $5.28 \mathrm{ml}$ te vermenigvuldigen met de leeftijd van het kuiken in dagen. Echter, door de genetische veranderingen bij vleeskuikens zijn deze gegevens waarschijnlijk niet meer up-to-date. Zo geeft Aviagen voor het Ross 308 kuiken aan dat de wateropname gelijk is aan 1,74 ml maal de voeropname (Aviagen, 2014b). Een kuiken van 40 dagen heeft dan volgens de managementgids een opname van $390 \mathrm{ml}$ water op die leeftijd (en zou volgens Pesti et al. (1985) slechts $238 \mathrm{ml}$ water opnemen). Voor verdere details van de wateropname in relatie tot de leeftijd wordt verwezen naar Aviagen (2014b). De procentuele wateropname ten opzichte van het gewicht voor het Ross 308 kuiken (momenteel meest gangbare vleeskuiken in Nederland) staat weergegeven in Figuur 5.1.

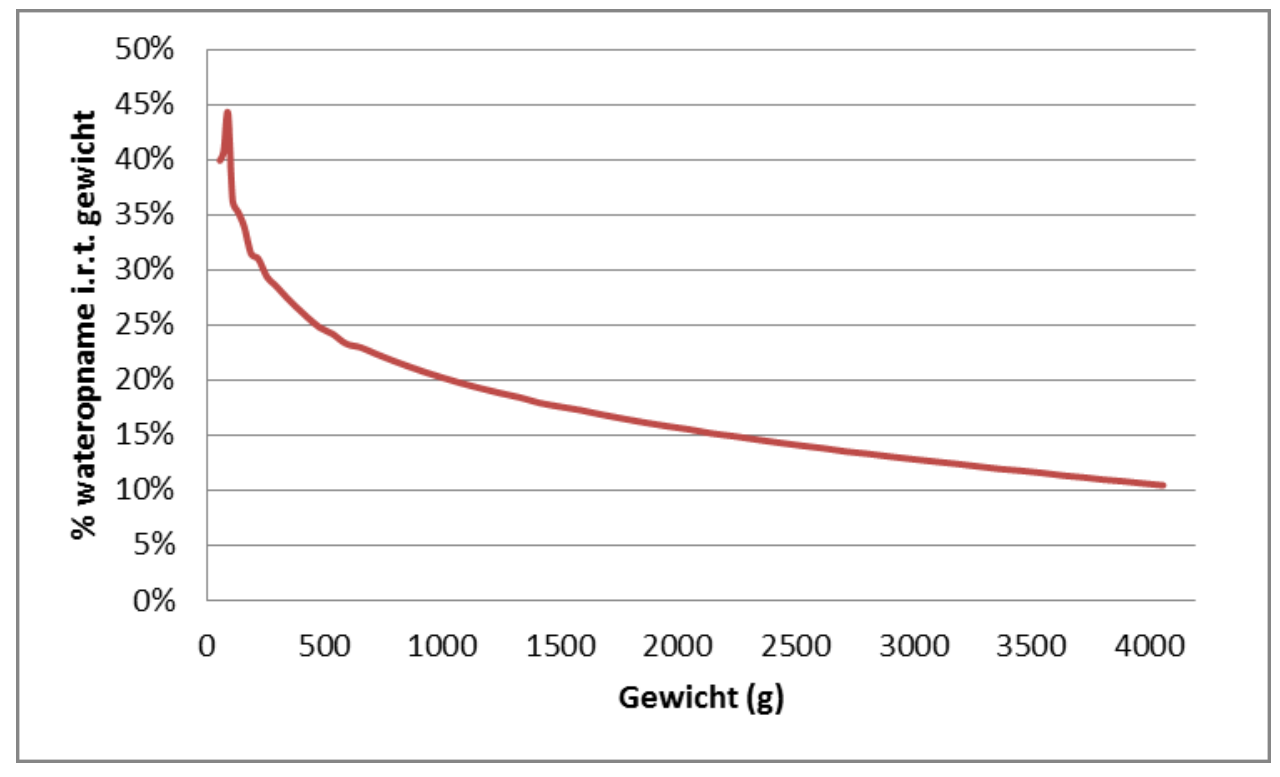

Figuur 5.1 Procentuele wateropname ten opzichte van het lichaamsgewicht voor Ross 308 vleeskuikens (Bron: Aviagen, 2014b).

\subsubsection{Gezondheidsstatus}

De waterconsumptie van vleeskuikens, zowel binnen een dag als binnen een productiecyclus, lijkt een goede indicator voor de gezondheid van vleeskuikens te zijn (Manning et al., 2007b). Terwijl de waterconsumptie over een productiecyclus indicatief is voor de gezondheid in de afgelopen periode, lijkt de dagelijkse consumptie een goede indicator voor het ontstaan van gezondheidsproblemen in het koppel en het risico op het ontstaan van nat strooisel (Manning et al., 2007a). Een hogere waterconsumptie van een koppel bleek gerelateerd te zijn aan nat strooisel. Wat betreft het ontstaan van gezondheidsproblemen (naast problemen veroorzaakt door nat strooisel) gaven de onderzoekers aan dat er meer onderzoek nodig was om te bepalen waar voor een koppel de grenswaarde ligt op basis waarvan actie ondernomen moet worden door de vleeskuikenhouder; deze grenswaarde is afhankelijk van een aantal factoren zoals de stal en locatie van de stallen (Manning et al., 2007a).

\subsubsection{Lichaamstemperatuurregeling}

In dit rapport wordt uitgegaan van thermoneutrale omstandigheden, dus het effect van hitte- of koudestress op de wateropname wordt hier verder niet beschreven. Uit de literatuur is bekend dat er 
een relatie is tussen hittestress, wateropname en de regeling van de lichaamstemperatuur, waarbij (koud) water kan helpen de lichaamstemperatuur te reguleren. De wateropname bij hittestress wordt aangepast aan de voeropname en ook de ervaring van de kuikens met hittestress speelt mee in de mate waarin de waterconsumptie wordt aangepast (Lott, 1991). Zie ook 5.4.1. watertemperatuur en 5.4.7. omgevingstemperatuur.

\subsubsection{Sociale facilitatie}

Kippen zijn van nature sociale dieren en sociale facilitatie van gedrag wordt vaak gezien, ook bij vleeskuikens onder commerciële huisvestingsomstandigheden. Sociale facilitatie wordt gedefinieerd als een toename van de frequentie van gedrag in een groep als gevolg van een respons op andere dieren in die groep die dat gedrag uitvoeren. Een bepaald gedrag kan zich op die wijze snel door een groep verspreiden (Collins and Sumpter, 2007; Asher and Collins, 2012). Sociale facilitatie wordt in de literatuur vaak genoemd in relatie tot stofbaden of voeropname, maar is ook een verschijnsel dat is waargenomen in relatie tot drinkgedrag (Franchina et al., 1986; Hoppitt and Laland, 2008).

\subsubsection{Adaptatie}

Bij vleeskuikenouderdieren is beschreven dat deze zich bij beperkte waterverstrekking aanpasten aan de duur van de periode van de beschikbaarheid van het water. Wanneer water dagelijks slechts een uur beschikbaar was, gingen alle dieren drinken binnen 15 minuten nadat het water beschikbaar was en namen ze in korte tijd een grote hoeveelheid water op (Ross et al., 1981). De auteurs gaven ook aan dat de dieren snel wenden aan het beperkte waterregime en dat er na enkele dagen geen sprake meer was van competitie bij de drinkers voorafgaand aan het water verstrekken (Ross et al., 1981). Er wordt in deze publicatie niets vermeld over competitie tussen dieren tijdens het drinken, wat ook afhankelijk is van de beschikbare ruimte aan de drinkers.

\subsection{Waterkwaliteitsfactoren}

De waterconsumptie van vleeskuikens is gerelateerd aan waterkwaliteit (Barton, 1996) en voersamenstelling (Belay, et al., 1993; Belay and Teeter, 1993; Teeter and Belay, 1996). Hoewel het drinkwater wellicht niet zo zuiver als gedestilleerd water hoeft te zijn, is het belangrijk dat drinkwater van goede kwaliteit wordt verstrekt. Bij de kwaliteit van het water moeten rekening gehouden worden met smaak en toxiciteit (Jones and Watkins, 2009).De grenswaarden voor de waterkwaliteit worden weergegeven in Tabel 5.1. Verontreinigd water kan leiden tot ziekten, lekkende drinknippels, nat strooisel en verhoogde productie van ammoniak en daardoor mogelijk verminderd welzijn (Barton, 1996; Bell, 2002; Butterworth, 2013; Carter and Sneed, 1987). Over de factoren waterhardheid (alkaliteit), zware metalenconcentratie, totale hoeveelheid opgeloste stoffen, bacteriële contaminatie, pH en opgelost zuurstof (Van der Hoeven-Hangoor, 2014) zijn geen specifieke relaties met waterconsumptie bij vleeskuikens bekend. De $\mathrm{pH}$ is een maat voor zuurgraad. Vleeskuikens hebben een ruime $\mathrm{pH}$-tolerantie, maar een $\mathrm{pH}$ lager dan 4 of hoger dan 8 (hoger dan 9 volgens Tabel 5.1) kan leiden tot minder waterverbruik (Van Harn and De Jong, 2012). Een aantal studies is uitgevoerd naar de effecten van ijzer $(\mathrm{Fe})$, mangaan $(\mathrm{Mn})$, nitraten $\left(\mathrm{NO}_{3}\right)$ in het drinkwater op de vleeskuikenproductie. De resultaten van deze studies laten zien dat zelfs zeer hoge niveaus van $\mathrm{Fe}$, Mn en $\mathrm{NO}_{3}$ geen invloed hebben op de gezondheid van vleeskuikens (Batal, et al., 2005a; Batal, et al., 2005b; Fairchild, et al., 2006a; Fairchild, et al., 2006b; Grizzle, et al., 1996; Grizzle, et al., 1997a; Grizzle, et al., 1997b; Ritz, et al., 2006).

De kwaliteit van het drinkwater wordt vooral beïnvloed door de mogelijke aanwezigheid van biofilm, een slijmerig laagje aan de binnenzijde van de drinkleiding. Een biofilm in een waterleiding ontstaat wanneer micro-organismen gaan groeien op afzettingen van mineralen en (organische) vuildeeltjes aan de wand van de leiding. Verhoogde hoeveelheden ijzer, mangaan, kalk, e.d. vergroten de kans op het ontstaan van een biofilm, maar kunnen ook extra slijtage, verstoppingen en lekkages tot gevolg hebben. Ook de (hulp)stoffen die gebruikt worden voor bijvoorbeeld vaccins, antibiotica, vitaminen, 
ontwormmiddelen kunnen de vorming van een biofilm bevorderen. De aanwezigheid van een biofilm in de drinkleiding kan mogelijk leiden tot een verminderde productie, gezondheidsproblemen, het afbreken of wegvangen van additieven, vermindering van de effectiviteit van een enting/medicatie, tot verstopping van nippels of juist lekkage en mogelijk bijdragen tot resistentievorming (Van Harn et al., 2014), maar onderbouwing uit de wetenschappelijke literatuur voor deze effecten ontbreekt.

Tabel 5.1 Gehanteerde grenswaarden voor waterkwaliteit pluimvee (Bron: GD, z.j.).

\begin{tabular}{|c|c|c|}
\hline Parameter & Norm Goed & Norm Slecht \\
\hline \multicolumn{3}{|l|}{ Chemisch } \\
\hline $\mathrm{pH}$ & 5 tot 8 & $<4$ en $>9$ \\
\hline ammonium (mg/L) & $<1$ & $>2$ \\
\hline nitriet (mg/L) & $<0,1$ & $>1,0$ \\
\hline nitraat (mg/L) & $<100$ & $>200$ \\
\hline chloride (mg/L) & $<200$ & $>300$ \\
\hline natrium (mg/L) & $<100$ & $>200$ \\
\hline ijzer (mg/L) & $<0,5$ & $>2,5$ \\
\hline mangaan (mg/L) & $<0,5$ & $>1,0$ \\
\hline sulfaat (mg/L) & $<100$ & $>250$ \\
\hline hardheid ( $\left.{ }^{\circ} \mathrm{D}\right)$ & 4 tot 15 & $>20$ \\
\hline \multicolumn{3}{|l|}{ Bacteriologisch } \\
\hline gisten en schimmels & - & $>10.000$ \\
\hline $\mathrm{E}$-coli $(\mathrm{kve} / \mathrm{ml})^{*}$ & $<10$ & $>100$ \\
\hline Totaal kiemgetal (kve/ml) & $<10.000$ & $>100.000$ \\
\hline $\mathrm{CZV}^{* *}(\mathrm{mg} / \mathrm{L})$ & $<50$ & $>100$ \\
\hline
\end{tabular}

\subsubsection{Nitraatconcentratie}

Het belang van deze factor is moeilijk te schatten; er zijn spaarzaam gegevens van gevonden. Een slechte waterkwaliteit samen met een hoge nitraatconcentratie hebben een negatieve invloed op de waterconsumptie (Grizzle et al., 1996). De bevinding is waarschijnlijk gerelateerd met de smaak en de $\mathrm{pH}$ van het drinkwater. Aanwezigheid van nitraat is daarbij een goede indicator dat het drinkwater gecontroleerd moet worden op bacteriën (Fairchild and Ritz, 2012).

\subsubsection{Smaak}

Smaak kan een grote invloed hebben op het waterverbruik van vleeskuikens. Kippen kunnen smaken onderscheiden (Kare, 1970). Smaakpapillen in de kippensnavel liggen voornamelijk op het achterste deel van het bovenste deel van de snavel, met slechts 2 tot 4 procent op de tong (Ganchrow and Ganchrow, 1985). Vleeskuikens hebben waarschijnlijk een voorkeur voor water dat lichtzuur en niet zoet is ( $\mathrm{pH}$ niet aangegeven) (Kare, 1970). Natuurlijke aversies wat betreft smaak die gebaseerd zijn op visuele of andere stimuli zijn meestal maar kortdurend en spelen op de lange termijn een kleine rol omdat het vleeskuiken flexibel qua smaak is (Hayne, et al., 1996; Marples and Roper, 1996).

\subsubsection{Reuk}

Het is al enige tijd bekend dat veel soorten vogels, waaronder kippen, een reukzin hebben (Jones and Roper, 1997). De functionele betekenis van deze reukzin is minder duidelijk. Waarschijnlijk speelt reukzin een rol bij de hechting aan voorwerpen of omgevingen; bij het uitlokken van angstreacties door alarm en predator-gerelateerde geuren, bij de controle van het eten en het drinken, en bij het vermijden van schadelijke stoffen. Het feit dat kippen een breed scala van geuren kunnen detecteren 
en daarop kunnen reageren binnen verschillende situaties is mogelijk van invloed op de wateropname, maar hier moet nog meer onderzoek naar uitgevoerd worden (Jones and Roper, 1997).

\subsubsection{Visuele verontreiniging}

Uit de grijze literatuur is de volgende samenvatting over kleur en watersamenstelling afkomstig (Fairchild and Ritz, 2012). Deze beschrijving is voor een deel gebaseerd op een serie experimenten (Batal et al., 2005a; Fairchild et al., 2005a; Fairchild et al., 2005b; Fairchild et al., 2006c). Water is kleurloos en elke kleur van het water kan een verhoogd niveau van vervuiling aangeven. Troebel water kan daarbij een lekkende drinkwatervoorziening veroorzaken. De waterhardheid (calcium en magnesium zouten) kan leidingen verstoppen en invloed hebben op ontsmettingsmiddelen en de toediening van medicijnen via het drinkwatersysteem. IJzer heeft effect op leidingen, maar lijkt niet van invloed op de gezondheid van vleeskuikens. Wel kan het leiden tot de vorming van een biofilm in de drinkwaterlijnen, met negatieve gevolgen voor de werking van de drinkers en de diergezondheid. Ook mangaan kan een dergelijke invloed hebben. Zie voor de mogelijke effecten van een biofilm de inleiding van deze paragraaf. Het handboek Kipsignalen geeft aan dat water van een goede kwaliteit helder en kleurloos is, geen bezinksel bevat en geen geur heeft (Bestman et al., 2009).

\subsubsection{Elektrolyten}

Tijdens periodes van potentiële hittestress wordt het drinkwater vaak aangevuld met elektrolyten (Ahmad and Sarwar, 2006; Lin et al., 2006; Mushtaq et al., 2013; Oliveira et al., 2016). Elektrolyten zijn mineralen in het bloed en van belang voor de normale celfunctie en -groei. De toevoeging van de elektrolyten vult niet alleen tekorten tijdens hittestress aan, maar bevordert ook het waterverbruik. Wanneer rekening wordt gehouden met beide resultaten (elektrolytinname en verhoogde waterconsumptie) kan sterfte door hittestress worden verminderd. Echter experimenten naar de beïnvloeding van de elektrolytenbalans geven onduidelijke resultaten en ondersteunen het voorgaande niet (Ahmad and Sarwar, 2006; Borges et al., 2004; Koike et al., 1983; Mushtaq et al., 2014; Mushtaq et al., 2013; Oliveira et al., 2016; Schafer, 2012).

\subsection{Voedingsfactoren}

\subsubsection{Voersamenstelling}

Wat betreft de relatie tussen wateropname en de factoren nutriëntenconcentratie, specifieke ingrediënten, mycotoxine contaminatie, droge stof gehalte, coccidiostatica en vorm van het voer (Van der Hoeven-Hangoor, 2014) zijn geen duidelijke wetenschappelijke onderzoeksresultaten voorhanden. Natte voeding heeft een negatieve invloed op de waterconsumptie, maar de totale wateropname (via de voeding en via de drinkers) is meestal hoger en de kwaliteit van het strooisel kan daardoor negatief worden beïnvloed (Forbes, 2003). Daarnaast hebben de mineralen $\mathrm{K}, \mathrm{Na}, \mathrm{Cl}$ en $\mathrm{Mg}$ een effect op de wateropname (Van der Hoeven-Hangoor, 2014). Een verhoogde mineralenconcentratie in het voer verhoogt het waterverbruik (Marks, 1987; Cengiz 2012; Enting et al., 2009), terwijl het verhogen van het niveau van ruw eiwit in het voer of een ongebalanceerde hoeveelheid ruw eiwit in het voer de opname van water en de water:voer verhouding verhoogt (De Jong et al., 2015; Pesti et al., 1985; Pesti and Marks, 1983; Shepherd and Fairchild, 2010). De effecten van voersamenstelling gelden voor zowel vleeskuikens als vleeskuikenouderdieren.

\subsubsection{Voerdeprivatie}

De beschikbaarheid van voer heeft een grote invloed op de inname van water, want onderzoek aan vleeskuikens laat zien dat voer- en wateropname zeer nauw gecorreleerd zijn (Butterworth, et al., 2002; Hocking et al., 1993; Hocking, et al., 1996; Pinchasov, et al., 1987; Savory, 1978). 
Vleeskuikens zullen, als ze geen toegang hebben tot voer, weinig water drinken, zelfs als water in ruime mate beschikbaar is. Omgekeerd zullen ze weinig of geen voer eten als ze geen toegang hebben tot water. De correlatie tussen voeding en waterverbruik wordt bij vleeskuikens geschat op 0,98 (Lott et al., 2003; Puma et al., 2001).

Bij vleeskuikenouderdieren leidt voerdeprivatie vaak tot meer pikken naar de drinknippel (D'Eath et al., 2009; Mench, 2002; Sandilands et al., 2005; Savory and Maros, 1993) en eventueel ook een hogere waterconsumptie (Hocking, 1993; Hocking, et al., 1993) of vermorsing van water (Jones et al., 2004). In veel gevallen kan teveel drinken of 'adjunctive' drinken (polydipsia) gezien worden als een stereotypie die indicatief is voor verminderd welzijn (Bennett and Leeson, 1989; Hocking et al., 2004; Hocking, 1993; Hocking et al., 1993; Kostal et al., 1992; Yeomans, 1986).

\subsection{Huisvestings- en managementfactoren}

Veel van de huisvestings- en managementfactoren die gerelateerd zijn aan wateropname hebben eveneens effect op de strooiselkwaliteit via o.a. lekkage van water en mede daardoor op het optreden van contact dermatitis (De Jong et al., 2012; De Jong et al., 2014; De Jong and Van Harn, 2016). Om lekkage en waterverspilling te voorkomen is o.a. het type drinker, het volledig horizontaal hangen van de drinklijn, het op de goede hoogte hangen van de drinklijn en de afwezigheid van lekkende nippels van belang (Van Harn et al., 2014a; Van Harn et al., 2014b; Van Harn et al., 2014c).

\subsubsection{Watertemperatuur}

Watertemperatuur speelt een nog niet geheel duidelijke rol bij de waterconsumptie (Teeter and Belay, 1996). Vleeskuikens zullen extreme dorst krijgen wanneer de temperatuur van het drinkwater meer dan twee graden boven hun lichaamstemperatuur is (Jones and Watkins, 2009). Alleen zolang de temperatuur van het gedronken water onder de lichaamstemperatuur zit, heeft het vleeskuiken enig voordeel voor de warmteafvoer en de regeling van de lichaamstemperatuur. Vleeskuikens zullen bij voorkeur water drinken met een temperatuur onder de lichaamstemperatuur en drinken zelfs ijskoud water (Kare, 1970). Verschillende studies hebben de effecten van het verstrekken van koud water tijdens warm weer onderzocht (Degen and Kam, 1998). In de meeste van deze studies zijn de prestaties van de vleeskuikens verbeterd. De voorkeur voor koud water geldt niet voor heel jonge kuikens, deze moeten juist hun lichaamstemperatuur op peil houden; voor jonge kuikens wordt een watertemperatuur van $25-30^{\circ} \mathrm{C}$ geadviseerd door het Klimaatplatform Pluimveehouderij (Ellen, pers. med.).

\subsubsection{Waterdruk}

Het verlagen van de waterdruk (Van Harn et al., 2009) gaf droger strooisel op dag 28 en dag 35 en daardoor minder ernstige hakdermatitis en voetzoollaesies. In het algemeen zullen waterdruk en waterafgifte (hoeveelheid water per tijdseenheid $(\mathrm{ml} / \mathrm{min})$ ) aan elkaar gerelateerd zijn, en zal een lagere waterdruk en waterafgifte de vermorsing en consumptie van water verminderen.

\subsubsection{Waterafgifte drinker}

De wateropbrengst of waterafgifte per tijdeenheid van een drinker is een belangrijke factor die van invloed is op de groei bij vleeskuikens. Drinknippels met te lage waterafgifte laten de prestaties afnemen (Lott et al., 2003). Er zijn ook een aantal abstracts verschenen (Cornelison et al., 2006; Lott et al., 2003; Pedersen and Thomsen, 2000; Radin et al., 1996) die geen duidelijke uitkomst geven. Precisie meting, controle en management zijn cruciaal voor het meten van stroomsnelheden (Miles et al., 2004). Een waterstroomsnelheid van $25 \mathrm{ml}$ per minuut bleek te weinig voor een optimale groei van een ouder vleeskuiken; beter was $75 \mathrm{ml}$ per minuut. Voor een jong kuiken kan $25 \mathrm{ml} / \mathrm{min}$ wel voldoende zijn. Een voldoende waterstroom (in $\mathrm{ml} /$ minuut) kan worden geschat door $7 \mathrm{ml}$ met de 
leeftijd in weken te vermenigvuldigen en daarbij 20 op te tellen. Een adequate drinknippelstroom voor 4 weken oude vleeskuikens zou zijn $7 \times 4=28+20=48 \mathrm{ml} / \mathrm{min}$ (Miles et al., 2004). In de praktijk wordt de waterafgifte per tijdseenheid verhoogd met de leeftijd (tussen $20 \mathrm{ml} / \mathrm{min}$ bij jonge kuikens en $100 \mathrm{ml} / \mathrm{min}$ bij vleeskuikens op slachtleeftijd (Van Harn, pers. med.).

\subsubsection{Drinker type}

De wateropname van vleeskuikens wordt beïnvloedt door het type drinker (ronddrinker vs. nippel drinker, zie ook hoofdstuk 3); vleeskuikens bezoeken de ronddrinkers minder vaak, maar hebben een grotere waterconsumptie per bezoek vergeleken met drinknippels (Bruno et al., 2011). Bij ronddrinkers, gebruikt bij vleeskuikenouderdieren, werd een grotere verspilling van water gevonden waardoor het strooisel natter werd (Colvero et al., 2014). Het gebruik van drinknippels bij vleeskuikens heeft geleid tot een beter beheer van het drinkwater en verbeteringen van de strooisel kwaliteit (Berg, 1998; Cornelison et al., 2005). Handboeken van Cobb, Hubbard en Ross vleeskuikens geven verschillende kenmerken van drinkers aan (Aviagen, 2014a; Cobb, 2008; Hubbard, 2014). Het drinker systeem beïnvloedt de water:voer verhouding (Aviagen, 2014a): 1) voor drinknippels zonder cups is deze $1,6: 1,2$ ) voor drinkcups $1,7: 1$ en voor ronddrinkers $1,8: 1$. In de praktijk is de verhouding 1,6:1 voor drinknippels niet gebruikelijk, omdat hedendaagse nippels een hogere waterafgifte hebben door het gebruik van opvangschoteltjes onder de nippels (Van Harn, pers. med.).

Van Middelkoop en Van Harn (1995) vonden in een onderzoek waarbij verschillende drinksystemen voor vleeskuikens werden vergeleken bij ronddrinkers, in vergelijking met drinknippels, een hoger waterverbruik en een hogere groei, daarentegen was de voerconversie en de strooiselkwaliteit bij ronddrinkers slechter. Bij hittestress, wanneer kuikens hijggedrag vertonen, bleek dat kuikens minder water opnamen uit hoge drinknippels dan uit lager hangende nippels (May et al., 1997) en dat kuikens minder water opnamen uit drinknippels dan uit ronddrinkers (Lott et al., 1998). De verklaring van de auteurs hiervoor is dat doordat de vleeskuikens hijggedrag vertonen, het lastiger lijkt te zijn om water op te nemen uit (hoge) nippels dan uit open drinkwatersystemen (May et al., 1997; Lott et al., 1998).

Uit onderzoek naar het effect van de kleur van drinknippels bleek dat kuikens een voorkeur hebben voor een bepaalde kleur nippel, alhoewel het contrast tussen de kleur van de nippel en de achterwand mogelijk ook een rol speelde, en leek de plaats van de nippel in de drinklijn (eind versus midden) ook een effect te hebben op het drinkgedrag van het kuiken (Van Niekerk, pers. med.). Verder onderzoek hiernaar is aan te bevelen.

\subsubsection{Drinker hoogte}

De hoogte van de drinknippel heeft geen invloed op gemiddelde productiekenmerken, maar wel van belang te zijn voor de hoeveelheid water die nodig is voor het behalen van een maximale productie (Quichimbo et al., 2013). Wanneer de drinkers iets te hoog hangen voor de kuikens, zodat deze er niet bij kunnen, kan dat tot grote mortaliteit leiden (Branton et al., 2001). Het is belangrijk dat een drinker op de correcte hoogte hangt. Een te laag hangende drinker leidt tot extra vermorsing, slechter strooisel en een grotere kans op contactdermatitis en als gevolg daarvan welzijnsproblemen. Een te hoog hangende drinker leidt tot een te geringe wateropname en een lagere groei (Van Harn, pers. med.). Management gidsen adviseren om bij jonge kuikens de drinknippels op een zodanige hoogte te

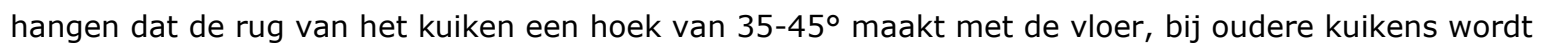
aangehouden dat het kuiken licht moet strekken om bij de nippel te kunnen en moet de rug van het kuiken een hoek van $75-85^{\circ}$ maken met de vloer (Aviagen, 2014a).

\subsubsection{Waterverspilling}

De minste waterverspilling bij het drinken wordt gevonden bij drinknippels en de meeste bij ronddrinkers (zie de paragraaf 5.4.4.), mits drinknippels op de juiste hoogte hangen en de juiste waterdruk wordt toegepast (Van Harn, pers. med.). 
Voerbeperking bij vleeskuikenouderdieren kan leiden tot meer 'drinkergericht gedrag' (pikken naar de nippel zonder waterconsumptie) en daarmee meer vermorsing (Jones et al., 2004).

\subsubsection{Omgevingstemperatuur}

Vleeskuikens laten een significante toename van waterconsumptie zien bij 30 en 35 graden Celsius (Belay and Teeter, 1993; Donkoh, 1989). Een van de belangrijkste manieren om de lichaamstemperatuur te reguleren is door het verdampen van water via de luchtwegen tijdens het hijgen. Het waterverbruik kan verdubbelen of zelfs verdrievoudigen in periodes van hittestress (Fairchild and Ritz, 2012). Vleeskuikens verhogen hun waterverbruik ongeveer 7 procent voor elke graad stijging van de omgevingstemperatuur (Fairchild and Ritz, 2012). Uit een ander experiment bleek dat de wateropname het laagst was tijdens de temperatuurpiek bij hittestress in verhouding tot voor of na de piek (May et al., 2000). Het is dus van belang dat bij hittestress voldoende water beschikbaar is. Gerealiseerd moet worden dat kippen bij hoge temperaturen altijd hijgen, ook als er voldoende drinkwater aanwezig is. De aan- of afwezigheid van hijgen is dus geen goede indicator voor de mate waarin drinkwater beschikbaar is.

\subsubsection{Ventilatie}

De wijze van ventilatie beïnvloedt de temperatuurhuishouding en daarmee de waterconsumptie (Lott et al., 1998). In een experiment met diverse luchtsnelheden en een hoge temperatuur bleek dat kuikens bij de hoogste luchtsnelheid het meeste aten, het minste water opnamen en het beste groeiden. De luchtsnelheid had weinig effect op de dagelijkse patronen van voer- en waterverbruik, deze bleven gelijk (May et al., 2000).

\subsubsection{Relatieve luchtvochtigheid}

Er is weinig expliciet onderzoek naar het effect van relatieve luchtvochtigheid op de waterconsumptie gedaan. Oud onderzoek beschrijft een optimale relatieve vochtigheid tussen 60 en $80 \%$ tijdens de opfokperiode en tussen 50 en 70\% na de opfokperiode (Winn and Godfrey, 1967). Deze hogere luchtvochtigheid lijkt de groei en voederconversie te bevorderen. Een hogere luchtvochtigheid geeft echter meer kans op nat strooisel. In het beschreven experiment was bijna 1,59 kg water per $\mathrm{kg}$ groei nodig (Winn and Godfrey, 1967). Er is geen recentere wetenschappelijk gepubliceerde informatie over relatieve luchtvochtigheid en watergebruik/drinken gevonden.

\subsection{Overige factoren}

Onderstaande factoren zijn niet genoemd in de tabel van Van der Hoeven-Hangoor (2014), maar zijn mogelijk wel van invloed op de waterconsumptie van vleeskuikens en vleeskuikenouderdieren.

\subsubsection{Licht en lichtregime}

Drinkgedrag wordt niet significant beïnvloed door de lichtintensiteit (Newberry et al., 1988), maar wel door het lichtregime en de bezettingsdichtheid (Sanotra et al., 2002). Continu licht vergeleken met een afwisseling tussen 16 uur licht en 8 uur donker (zie figuur 5.2) beïnvloedt het dagelijkse verloop in de wateropname bij vleeskuikens (Sanotra et al., 2002). Bij natuurlijk licht en ook bij kunstlicht treden er meestal twee pieken in het waterverbruik op (Fairchild and Ritz, 2012). De eerste is in de vroege ochtend, als de zon opkomt en dieren actief worden. De tweede is in de schemering, wanneer veel dieren anticiperen op de nacht door te gaan drinken. Met kunstmatige verlichting zien we veelal hetzelfde patroon. De waterconsumptie neemt toe wanneer de lichten voor het eerst aangaan en na een afname neemt het later weer toe vlak voordat de lichten uitgaan. Tijdens de donkere periodes rusten de vleeskuikens zonder dat water verbruikt wordt bij periodes van maximaal 8 uur donker 
(Fairchild and Ritz, 2012). Tussen de pieken door zal de waterconsumptie gerelateerd zijn aan de voeropname (bij onbeperkte waterverstrekking) (Murphy and Preston, 1988;Puma et al., 2001; Hoppitt and Laland, 2008).

\subsubsection{Bezettingsdichtheid}

De hoeveelheid licht en de bezettingsdichtheid hebben invloed op het drinkgedrag gedurende de dag (Sanotra et al, 2002) en zie figuur 5.2. Bij een hoge dichtheid (30 dieren per $\mathrm{m}^{2}$ ) is het drinkgedrag van vleeskuikens als percentage van de tijdbesteding verlaagd (Sanotra et al., 2002), terwijl bij alle bezettingen er maximaal 21 kuikens per nippel waren. Wanneer de ventilatie en luchtcirculatie optimaal zijn en de afstand tot de drinknippels kort is en er voldoende nippels aanwezig zijn kunnen ook vleeskuikens in de hoogste dichtheid voldoende water consumeren (Feddes, et al., 2002; Feddes, et al., 2003); het waterverbruik per vleeskuiken neemt echter af bij toenemende bezettingsdichtheid en neemt niet-significant af bij toenemende drinknippelbezetting. Bij hoge dichtheden zullen zieke, kleine of zeer lichte dieren kunnen sterven wanneer ze niet meer in staat zijn bij drinknippels te komen (Feddes et al., 2002). Er is een relatie gevonden tussen dehydratie en kreupelheid bij vleeskuikens (Butterworth et al., 2002).

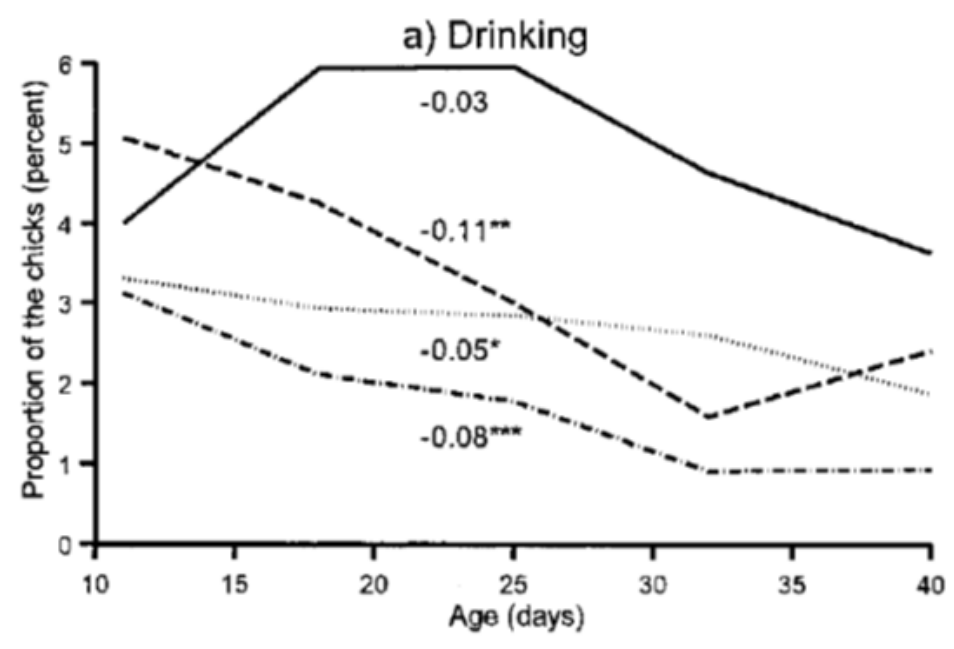

Figuur 5.2 Effect van 4 verschillende huisvestingsomstandigheden (van boven naar beneden) op drinkgedrag uitgezet tegen de leeftijd: 1) 16 uur licht - 8 uur donker en lage bezettingsdichtheid (18 vleeskuikens per $\mathrm{m}^{2}$ ); Richtingscoefficient, $R C=-0.03$, doorgetrokken lijn; 2) 16 uur licht - 8 uur donker en hoge bezettingsdichtheid (30 vleeskuikens per $\mathrm{m}^{2}$ ); RC=-0.11, onderbroken lijn; 3) continu licht en lage bezettingsdichtheid; $R C=-0.05$, gestippelde lijn; en 4) continu licht en hoge bezettingsdichtheid; $R C=-0.08$, onderbroken en gestippelde lijn (Sanotra et al., 2002). 


\section{6 \\ Methoden van waterverstrekking aan vleeskuikens en vleeskuikenouderdieren en het effect op dierenwelzijn}

\section{$6.1 \quad$ Vleeskuikens}

\subsubsection{De praktijk in Nederland}

Op verreweg de meeste vleeskuikenbedrijven in Nederland wordt water verstrekt via drinknippels, al dan niet voorzien van lek- of opvangschoteltjes onder de nippel. Een voorbeeld hiervan wordt weergegeven in figuur 6.1. Het aantal bedrijven dat gebruik maakt van drinkcups wordt geschat op maximaal een paar procent (Van Harn en Ellen, pers. med.) en mogelijk komen ronddrinkers nog zeer sporadisch voor. Dit komt overeen met gegevens geregistreerd in het kader van de welzijnsmonitor vleeskuikens in 2011, 2013 en 2014, waarbij de overgrote meerderheid van de gemonitorde bedrijven gebruik maakte van drinknippels, een paar bedrijven van drinkcups en één (biologisch) vleeskuikenbedrijf gebruik maakte van ronddrinkers (De Jong, pers. med.).

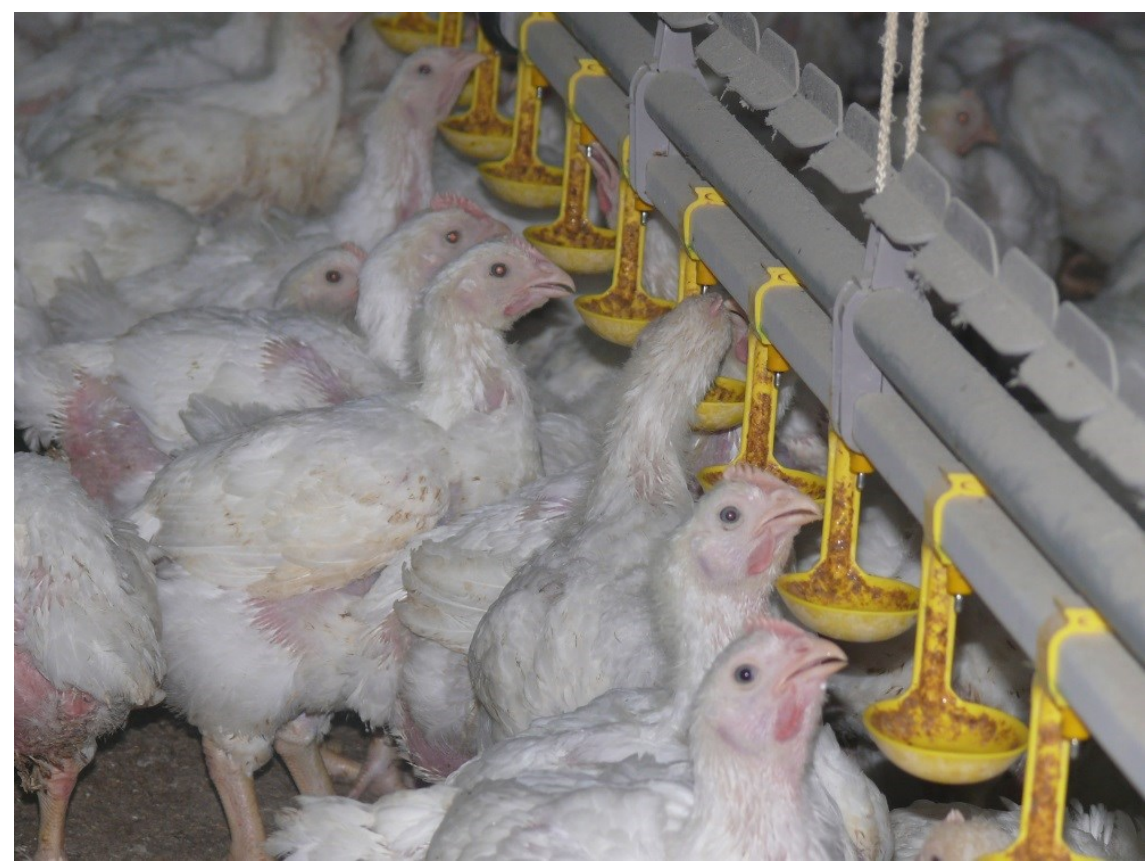

Figuur 6.1 Drinkwaterverstrekking bij vleeskuikens via een nippel met lekbakje.

Er zijn geen gepubliceerde gegevens beschikbaar over het aantal Nederlandse vleeskuikenbedrijven waar beperkt of onbeperkt water wordt verstrekt. Methoden waarmee in de praktijk de watergift wordt gecontroleerd zijn volgens de geconsulteerde stakeholders, naast kortdurend in het donker zetten van de kuikens tijdens de lichtperiode (eventueel in combinatie met de kraan uitzetten), het verlagen van de waterdruk (waardoor de waterafgifte per tijdseenheid wordt gereduceerd), het water gedurende een beperkte periode uitzetten (bijvoorbeeld één uur uit op vijf uur aan), de lichtsterkte tijdelijk verlagen, het aanzuren of verstrekken van andere toevoegingen aan het drinkwater en het oplieren van één of meerdere drinklijnen. Dit laatste, het oplieren van drinklijnen, wordt bij reguliere vleeskuikens alleen in de eerste weken toegepast. In alternatieve systemen met trager groeiende kuikens wordt dit soms gedurende de gehele productieperiode toegepast, vaak vanwege het feit dat de stal voorheen werd gebruikt voor reguliere kuikens en er dus meer kuikens werden gehuisvest en een overschot aan drinkpunten aanwezig is (Van Harn, pers. med.). De geconsulteerde stakeholders 
zijn niet uniform in de definitie die ze hanteren van beperkte waterverstrekking. Indien de methoden die hierboven worden genoemd (verlagen waterdruk, additieven toevoegen, donker zetten van kuikens, variëren in lichtsterkte of kortdurend (een uur) de kraan dichtzetten) gezien worden als waterbeperking, dan wordt op 90-100\% van de bedrijven het water beperkt verstrekt aan vleeskuikens (één stakeholder geeft aan 30-50\%). Sommige stakeholders geven expliciet aan dat ze het kortdurend donker zetten van de kuikens in de lichtperiode niet zien als waterbeperking ('kuikens drinken niet in het donker') en geven daarom aan dat op nagenoeg $100 \%$ van de bedrijven de watergift niet wordt beperkt.

\subsubsection{Effect van beperking van de watergift op het welzijn van vleeskuikens}

In de wetenschappelijke literatuur wordt aangegeven dat vleeskuikens in de praktijk meestal niet worden beperkt in de watergift maar dat er wel methoden worden toegepast om de watervermorsing te beperken en zo het strooisel droog te houden, en daarmee de nadelige gevolgen van nat strooisel te voorkomen (zoals voetzoollaesies, hakdermatitis en borstirritatie of -blaren) (bijvoorbeeld De Jong, et al., 2012; Houldcroft et al., 2008; Vanderhasselt, 2013). Het feit dat langdurige waterbeperking meestal niet wordt toegepast bij vleeskuikens is mogelijk de reden dat de hoeveelheid wetenschappelijke publicaties met betrekking tot het effect van waterbeperking bij vleeskuikens zeer beperkt is. Droog strooisel is niet alleen van belang voor het welzijn van vleeskuikens omdat het risico op contact dermatitis wordt verkleind, maar ook omdat het vleeskuikens de mogelijkheid biedt tot stofbaden en scharrelen (Shields et al., 2004), belangrijke aspecten van hun natuurlijke gedragsrepertoire (SCAHAW, 2000; EFSA, 2010a).

In een van de eerste onderzoeken naar beperkte waterverstrekking bij vleeskuikens werd de groei in enige mate gereduceerd door 48 tot 72 uur waterdeprivatie maar het absolute verschil in vergelijking tot de controle (niet-gedepriveerde) groep en groepen blootgesteld aan 24 uur waterdeprivatie was klein (Arscott, 1969). Er werden geen significante verschillen in voeropname, voederconversie of totaal waterverbruik waargenomen tussen de controle (niet-watergedepriveerde) groep en vleeskuikens die wateronthouding kregen gedurende 24, 48 of 72 uur. De waterconsumptie was gerelateerd aan de duur van de periode van waterdeprivatie wanneer na deprivatie opnieuw water werd gegeven (Arscott, 1969). In een onderzoek naar waterbeperking bij vleeskuikens in een warme, vochtige tropische omgeving werden wel sterke effecten van waterbeperking op het lichaamsgewicht en voerconversie gevonden (Abdelsamie and Yadiwilo, 1981).

Vermagering en uitdroging zijn veelal indicaties van het onvermogen van het individuele vleeskuiken om voer en/of water op te nemen, bijvoorbeeld bij kleine vleeskuikens die niet meer bij de drinkers kunnen komen wanneer die hoger worden geplaatst. Uitdroging en vermagering zijn altijd aanwijzingen voor een slecht welzijn en verminderde gezondheid, zoals loop- of pootproblemen (Butterworth, 1999; Butterworth et al., 2002; Kestin, et al., 2001). Waterbeperking vroeg in de opgroeiperiode beïnvloedt de productie (eindgewicht) en de mogelijkheid van het vleeskuiken om immunologische reacties te vertonen negatief (Toghyani et al., 2011). Wanneer de watergift werd beperkt bleken vleeskuikens vooral veranderingen in hun gedrag te vertonen en werden ze agressief en geïrriteerd. In dit onderzoek werden vleeskuikens blootgesteld aan verschillende niveaus van waterrestrictie (0-40\%) tussen dag 1 en 21 . Het bleek dat er wel een effect was op de groei maar dat de mortaliteit niet werd beïnvloed door de waterrestrictie (onder thermoneutrale condities) (Viola et al., 2009). De conclusie van deze onderzoekers was dat waterbeperking bij vleeskuikens ongeacht de mate van beperking moet worden vermeden (Viola et al., 2009). Toch is gevonden dat vleeskuikens snel herstellen van waterbeperking in de eerste week wanneer ze normaliter (dus in de rest van hun leven) onder goede omstandigheden gehouden worden (Castro et al., 2009). Wanneer de watergift wordt beperkt kan dat dorst veroorzaken. Dorst is een subjectieve perceptie die dieren motiveert om te drinken (Sprenger et al., 2009). Langdurige dorst veroorzaakt stress, verzwakking, conditieverlies en ziekte (Jones et al., 2009). Ook vermindert het de voeropname en veroorzaakt daardoor honger. Belangrijke oorzaken voor het optreden van dorst zijn slechte waterkwaliteit of watervoorziening en competitie met soortgenoten bij waterbeperking (bijvoorbeeld bij onvoldoende drinkers) (Jones et al., 2009) (zie hoofdstuk 5). 
$\mathrm{Er}$ is weinig bekend over de effecten van de nu in de praktijk toegepaste methoden van waterbeperking/gecontroleerd water verstrekken op het welzijn van vleeskuikens. Uit onderzoek van Van Harn en De Jong (2012) bleek dat het aanzuren van drinkwater leidde tot een beperking in de wateropname en daardoor droger strooisel en minder voetzoollaesies. Hetzelfde werd gevonden voor het verlagen van de waterdruk (waterstroom) (Van Harn et al., 2009). Daardoor wordt het risico op welzijnsaantasting door voetzoollaesies verkleind. Of de kuikens mogelijk ongerief ondervinden als gevolg van de methoden van waterbeperking (aanzuren of verlagen van de waterdruk) op zich, is onbekend. Wanneer kuikens de keuze kregen tussen aangezuurd en niet aangezuurd water bleek wel dat de voorkeur van vleeskuikens uitging naar niet aangezuurd water (Van Harn en De Jong, 2012).

\subsubsection{Risico inventarisatie methoden van waterbeperking/gecontroleerd verstrekken van water aan vleeskuikens}

Visser et al. (2015) hebben door middel van een expertconsultatie een risico inventarisatie uitgevoerd bij vleeskuikens met betrekking tot het ongerief veroorzaakt door verminderde wateropname. Het resultaat hiervan staat weergegeven in Tabel 6.1 .

Tabel 6.1 Impact van ongerief als gevolg van verminderde wateropname bij vleeskuikens (Visser et al., 2015). Op basis van deskstudie en expert opinie (WUR Livestock Research) is de ernst, duur, impact en prevalentie van verminderde wateropname bij vleeskuikens geschat. De ernst is beoordeeld op een schaal van 1 tot 5 (welzijnsaantasting afwezig (1) tot zeer ernstige welzijnsaantasting (5)), de duur op een schaal van 1-3 (kort-middel-lang). De combinatie van deze scores leidde tot een score voor impact op een schaal van 1-7 (geen impact op het dier tot veel impact op het dier) (Visser et al., 2015).

\begin{tabular}{llccc}
$\begin{array}{l}\text { Welzijnsprobleem } \\
\text { (=ongerief als gevolg van ....) }\end{array}$ & Ernst & Duur & Impact & $\begin{array}{l}\text { Prevalentie } \\
\text { in \% dieren }\end{array}$ \\
\hline $\begin{array}{l}\text { Verminderde wateropname } \\
{ }^{1} \text { (Vanderhasselt, 2013) }\end{array}$ & $3^{1}$ & $2^{2}$ & 4 & $1-10$ \\
${ }^{2}$ (Butterworth et al., 2002) & & & & \\
\hline
\end{tabular}

Uit deze risico inventarisatie bleek dat verminderde wateropname een redelijke impact heeft op het welzijn van het kuiken (score 4, maximale score 7) maar dat de prevalentie (de mate waarin het in de gangbare praktijk voorkomt) wordt ingeschat als laag (Visser et al., 2015).

In aanvulling op de risico inventarisatie uitgevoerd door Visser et al. (2015) is in het kader van dit rapport een aanvullende risico inventarisatie uitgevoerd op basis van expertopinie waarbij onderscheid gemaakt is tussen de verschillende methoden van waterbeperking/gecontroleerde waterverstrekking die momenteel in de praktijk worden toegepast. De resultaten daarvan staan weergegeven in Tabel 4. Uit Tabel 6.2 komt naar voren dat de experts inschatten dat de toegepaste methoden voor het beperken van de wateropname bij vleeskuikens, zoals ze in de gangbare praktijk worden toegepast, geen risico vormen voor het welzijn van de vleeskuikens. De experts gaven hierbij aan dat de donkerperiode meestal zodanig kort is dat niet wordt verwacht dat de kuikens stress ondervinden doordat ze geen water op kunnen nemen tijdens deze relatief korte periode. Bij het oplieren van drinklijnen is het uitgangspunt dat er nog voldoende drinklijnen overblijven om alle kuikens voldoende water te laten opnemen, wat voor zover bekend in de praktijk meestal het geval is. Ook bij de andere methoden schatten experts dat de kuikens bij gecontroleerde verstrekking nog steeds voldoende water op kunnen nemen. Als dat namelijk niet zo is, leidt het tot productievermindering en zal een vleeskuikenhouder daar economisch nadeel van ondervinden. 
Tabel 6.2 Impact van ongerief als gevolg van methoden van waterbeperking bij vleeskuikens. Op basis van expert opinie (experts Wageningen Livestock Research) is de ernst, duur en impact van methoden van waterbeperking bij vleeskuikens geschat. De spreiding is tussen haakjes weergegeven. De ernst is beoordeeld op een schaal van 1 tot 5 (welzijnsaantasting afwezig (1) tot zeer ernstige welzijnsaantasting (5)), de duur op een schaal van 1-3 (kort-middel-lang). De combinatie van deze scores leidde tot een score voor impact op een schaal van 1-7 (geen impact op het dier tot veel impact op het dier) (Visser et al., 2015).

\begin{tabular}{llll}
$\begin{array}{l}\text { Ongerief als gevolg van } \\
\text { verminderde wateropname }\end{array}$ & Ernst & Duur (spreiding) & Impact \\
door r.n. & 1 & 1 & 1 \\
\hline $\begin{array}{l}\text { Donker zetten } \\
\text { Verlagen waterdruk }\end{array}$ & 1 & $2(2-3)$ & 1 \\
\hline $\begin{array}{l}\text { Aanzuren of chloreren } \\
\text { drinkwater }\end{array}$ & 1 & $2(2-3)$ & 1 \\
\hline $\begin{array}{l}\text { Lichtsterkte variëren (tijdelijk } \\
\text { lagere lichtsterkte) }\end{array}$ & 1 & $2(1-3)$ & 1 \\
\hline $\begin{array}{l}\text { Kortdurend geen water } \\
\text { verstrekken (bv 1 uur geen : } 5\end{array}$ & 1 & 1 & 1 \\
uur wel water) & 1 & 1 & 1 \\
\hline \begin{tabular}{l} 
Oplieren van drinklijnen \\
\hline
\end{tabular}
\end{tabular}

\subsection{Vleeskuikenouderdieren}

\subsubsection{De praktijk in Nederland}

Drinknippels worden naar schatting op 75\% van de opfokbedrijven (0-20 weken leeftijd) en 50-70\% van de vermeerderingsbedrijven ( 20 - circa 60 weken leeftijd) toegepast, de overige bedrijven gebruiken ronddrinkers. Bij opfokbedrijven worden vaak beide watersystemen aangeboden waarbij één van beide de hoofd drinkwatervoorziening is (zie figuur 6.2). De dieren kunnen op deze wijze wennen aan verschillende wijzen van drinkwatervoorziening ter voorbereiding op de productieperiode. Figuur 6.3 geeft een voorbeeld van een ronddrinker voor vleeskuikenouderdieren. 


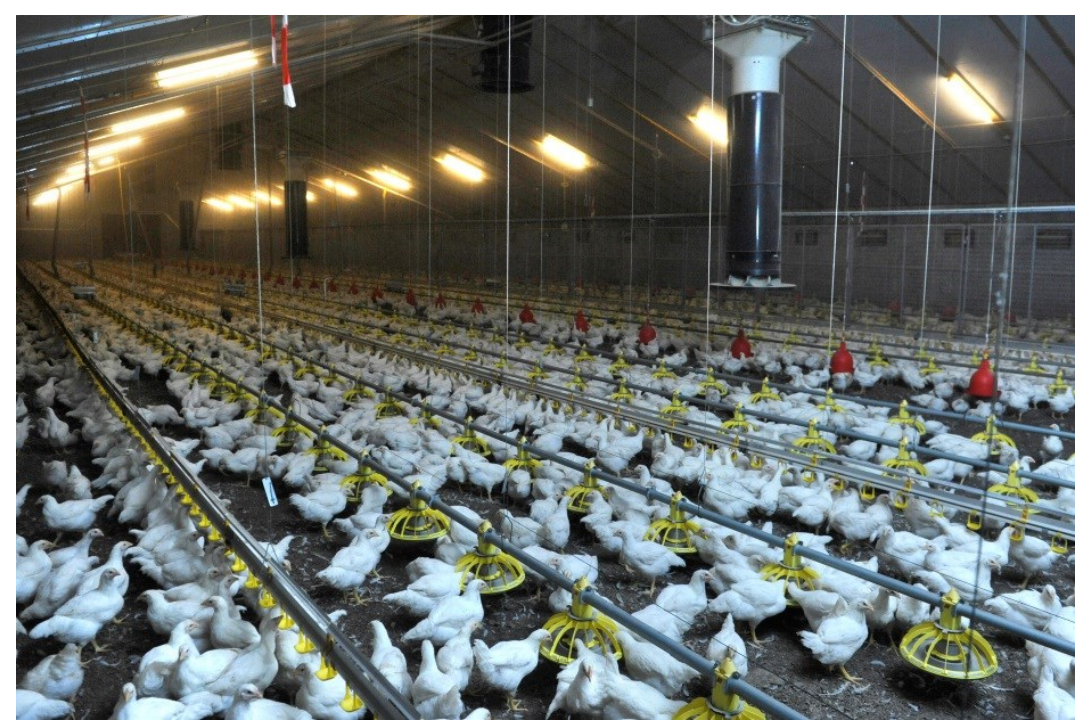

Figuur 6.2 Drinkwaterverstrekking aan vleeskuikenouderdieren in de opfokperiode. Links is de nippellijn met lekbakjes te zien, rechts de rode ronddrinkers.

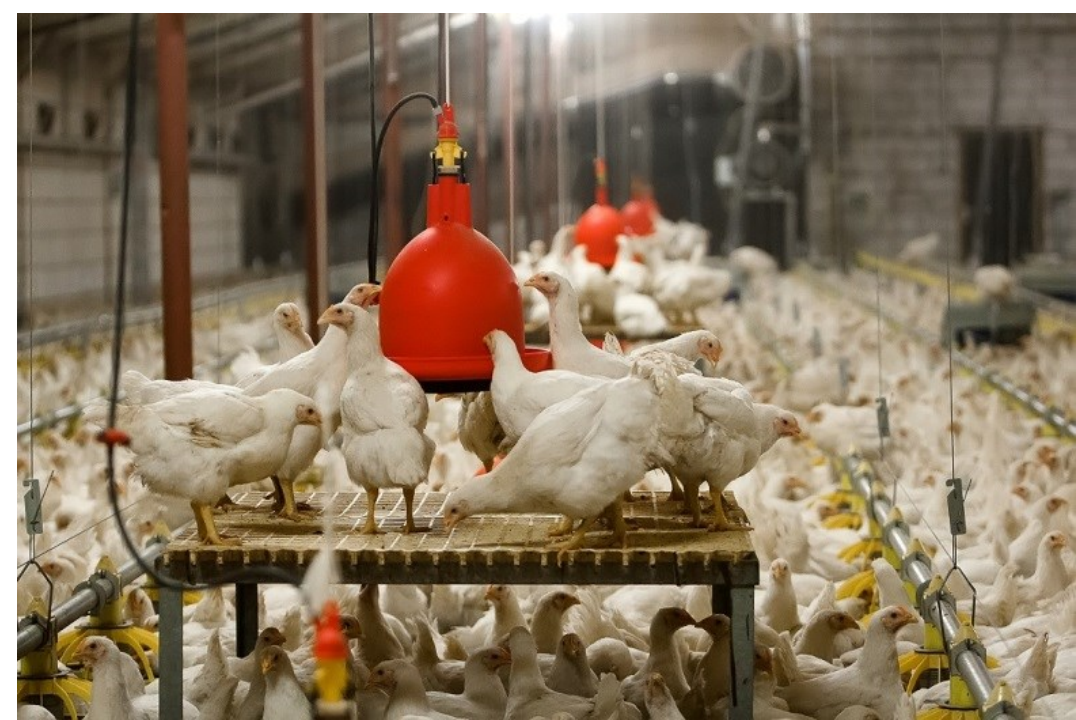

Figuur 6.3 Drinkwaterverstrekking via een ronddrinker bij vleeskuikenouderdieren in de opfokperiode.

Er zijn geen gepubliceerde gegevens beschikbaar over het aantal Nederlandse opfokbedrijven of vermeerderingsbedrijven waar beperkt of onbeperkt water wordt verstrekt. In de literatuur wordt aangegeven dat beperkte waterverstrekking na de eerste levensweken (internationaal) algemeen wordt toegepast bij vleeskuikenouderdieren van gangbare (snelgroeiende) vleeskuikenrassen in de opfok- en productieperiode (EFSA, 2010b), hoewel uit de stakeholderconsultatie bleek dat inmiddels in een aantal landen waterbeperking niet meer gangbaar is bij vleeskuikenouderdieren. Management gidsen geven aan dat schoon drinkwater beschikbaar moet zijn wanneer de dieren actief zijn (Aviagen, 2013; Cobb, 2008). Een expert uit Zweden gaf aan dat in principe water daar onbeperkt wordt verstrekt in de opfok- en productieperiode (bij ouderdieren van gangbare vleeskuikenrassen), maar dat het in de praktijk voorkomt dat opfokkers en vermeerderaars het water gedurende een korte periode (bijvoorbeeld een uur tijdens de lichtperiode) uitzetten, de reden waarom dit gebeurt is niet bekend.

Door de stakeholders wordt aangegeven dat waterbeperking bij 90-95\% van de opfokbedrijven wordt toegepast en bij 85-95\% van de vermeerderingsbedrijven in Nederland. De geraadpleegde stakeholders geven aan dat de mate van waterbeperking afhankelijk is van de gebruikte foklijn (merk). Bij ouderdieren van gangbare (snelgroeiende) vleeskuikens wordt het water tijdens de opfokperiode meestal verstrekt gedurende een beperkt aantal uren rondom het voeren (vast aantal uren of door middel van een vaste water:voer verhouding) en bij een klein aantal bedrijven door vermindering van de waterdruk. In de productieperiode worden dezelfde methoden toegepast. Bij ouderdieren van trager groeiende vleeskuikens wordt langer of helemaal onbeperkt water verstrekt. 
Dit heeft te maken met het feit dat deze ouderdieren meestal veel minder beperkt worden in hun voeropname of zelfs onbeperkt worden gevoerd (Jones, Zaczek, MacLeod and Hocking, 2004).

Bij vleeskuikenouderdieren worden drie methoden van beperkt waterverstrekken toegepast; water wordt beperkt verstrekt met voeren tot 2-4 uur nadat het voer op is, water wordt verstrekt in een vaste water: voer verhouding (als voorbeeld wordt 1,7-1,8 genoemd) en als deze verhouding is bereikt gaat de kraan dicht, en als derde wordt het verlagen van de waterdruk genoemd. Aangegeven werd dat ongeveer $30 \%$ van de bedrijven (opfok en vermeerdering) werkt met een vaste water:voer verhouding, ongeveer $60 \%$ met een tijdslimiet (vast aantal uren water) en ongeveer $10 \%$ met een lage waterdruk.

Daarnaast wordt de opmerking gemaakt dat tijdens warme perioden sommige opfokkers en vermeerderaars onbeperkt water verstrekken of extra water verstrekken gedurende minimaal een periode van 1 tot 2 uur aan het einde van de lichtperiode.

\subsubsection{Effect van waterbeperking of onbeperkte waterverstrekking op het welzijn van vleeskuikenouderdieren}

Uit onderzoek van Hocking et al. (1993) bleek dat waterbeperking (water beschikbaar gedurende 2-3 uur per dag) bij beperkt gevoerde vleeskuikenouderdieren geen effect had op de gemeten welzijnsindicatoren (zoals plasma corticosteron concentratie, heterofiel:lymfocyt ratio in het bloed, plasma viscositeit en totaal oraal stereotiep pikgedrag) in vergelijking met onbeperkte waterverstrekking aan beperkt gevoerde vleeskuikenouderdieren. Drinkgedrag bij beperkt gevoerde vleeskuikenouderdieren wordt gezien als een vorm van 'stereotiep oraal gedrag', dit stereotiep pikgedrag wordt bij waterbeperking meestal niet op de drinker gericht maar bijvoorbeeld naar het strooisel of onderdelen van het hok (Hocking et al., 1993) en is indicatief voor verminderd welzijn. Onderzoek heeft aangetoond dat stereotiep pikgedrag in verschillende vormen waargenomen kan worden, bijvoorbeeld door pikken naar de voerbak, de drinker, het strooisel, andere dieren, onderdelen van het hok en meestal als combinatie van deze gedragingen (Sandilands et al., 2005), en de vorm van dit stereotiep pikgedrag verschilt van koppel tot koppel (of experiment tot experiment). De mate waarin het op de drinker wordt gericht lijkt afhankelijk te zijn van de beschikbaarheid van water in de drinker (o.a. Hocking et al., 1993; Sandilands et al., 2005). Aangetoond is dat bij het pikken naar de nippel bij onbeperkte waterverstrekking aan beperkt gevoerde ouderdieren er meestal geen sprake is van daadwerkelijke consumptie maar vooral van verspilling (Jones et al., 2004), alhoewel ook wordt gerapporteerd dat beperkt gevoerde vleeskuikenouderdieren daadwerkelijk meer water consumeren dan onbeperkt gevoerd vleeskuikenouderdieren wat kan leiden tot natte mest (Hocking, 1993; Hocking et al., 1993; 1996). Wanneer vleeskuikenouderdieren niet dagelijks werden gevoerd werd de wateropname aangepast aan het voerpatroon, maar bleef de totale waterconsumptie gelijk (Bennett and Leeson, 1989).

In de literatuur wordt als reden van beperkte waterverstrekking aan vleeskuikenouderdieren genoemd dat de wateropname te hoog wordt bij beperkt gevoerde dieren, met kans op natte mest en daardoor nat strooisel en het risico op contactdermatitis, door het ontstaan van stereotiep pikgedrag naar de drinker (EFSA, 2010b; Yeomans, 1986; Bennett and Leeson, 1989; Kostal et al., 1992; Hocking, 1993; Hocking et al., 1993; Hocking et al., 2004). In een artikel van ruim twintig jaar geleden werd aangegeven dat het stereotiepe drinkgedrag mogelijk leidde tot overmatige waterconsumptie (polydipsia) (Kostal et al., 1992). Het lijkt echter niet waarschijnlijk dat er inderdaad sprake is van polydipsia bij onbeperkte waterverstrekking aan beperkt gevoerde vleeskuikenouderdieren (Jones et al., 2004). Vermindering van de eetmotivatie zal leiden tot minder stereotiep oraal gedrag en daarmee tot een afname van de waterconsumptie of -verspilling bij onbeperkte waterverstrekking (EFSA, 2010b). Daarom worden dwergvleeskuikenmoederdieren, die minder in hun voeropname beperkt hoeven worden of zelfs helemaal onbeperkt gevoerd kunnen worden, in principe niet beperkt in de watergift (Marks, 1987; Jones et al., 2004). 


\subsubsection{Risico inventarisatie methoden van waterbeperking bij vleeskuikenouderdieren}

Visser et al. (2015) hebben door middel van een expertconsultatie een risico inventarisatie uitgevoerd bij vleeskuikenouderdieren met betrekking tot het ongerief veroorzaakt door verminderde wateropname. Het resultaat hiervan staat weergegeven in Tabel 6.3.

Tabel 6.3 Impact van ongerief als gevolg van verminderde wateropname bij vleeskuikenouderdieren tijdens de opfok en productiefase (Visser et al., 2015).

Op basis van deskstudie en expertopinie (WUR Livestock Research) is de ernst, duur, impact en prevalentie van het ongerief als gevolg van verminderde wateropname bij vleeskuikenouderdieren tijdens de opfok- en produtiefase ingeschat. De ernst is beoordeeld op een schaal van 1 tot 5 (welzijnsaantasting afwezig (1) tot zeer ernstige welzijnsaantasting (5)), de duur op een schaal van 13 (kort-middel-lang). De combinatie van deze scores leidde tot een score voor impact op een schaal van 1-7 (geen impact op het dier tot veel impact op het dier) (Visser et al., 2015).

\begin{tabular}{|c|c|c|c|c|}
\hline $\begin{array}{l}\text { Welzijnsprobleem } \\
\text { (=ongerief als gevolg van ...) }\end{array}$ & $\begin{array}{l}\text { Ernst } \\
\text { [bron] }\end{array}$ & $\begin{array}{l}\text { Duur } \\
\text { [bron] }\end{array}$ & Impact & $\begin{array}{l}\text { Prevalentie in } \\
\% \text { dieren [bron] }\end{array}$ \\
\hline Verminderde wateropname in de opfokfase & $3^{1}$ & 3 & 5 & $2-100^{3}$ \\
\hline Verminderde wateropname in de productiefase & $3^{1}$ & $3^{2}$ & 5 & $2-100$ \\
\hline \multicolumn{5}{|l|}{${ }^{1}$ (Vanderhasselt et al., 2013) } \\
\hline \multicolumn{5}{|l|}{${ }^{2}$ (Butterworth et al., 2002) } \\
\hline${ }^{3}(E F S A, 2010 b)$ & & & & \\
\hline
\end{tabular}

Uit deze risico inventarisatie bleek dat verminderde wateropname een behoorlijke impact heeft op het welzijn van het ouderdier, zowel in de opfok- als vermeerderingsfase (score 5, maximale score 7) maar dat de prevalentie zeer variabel kan zijn. De variatie in prevalentie zal afhangen van de reden waarom een dier minder water op kan nemen (competitie bij drinkers, gezondheidsproblemen) in combinatie met al dan niet beperkte waterverstrekking (afhankelijk van het merk/type kuiken) (Jones et al., 2004).

In aanvulling op de risico inventarisatie uitgevoerd door Visser et al. (2015) is in het kader van dit rapport een aanvullende risico inventarisatie uitgevoerd op basis van expertopinies waarbij onderscheid gemaakt is tussen de verschillende methoden van waterbeperking die momenteel in de praktijk worden toegepast in de opfok- en productiefase. De resultaten daarvan staan weergegeven in Tabel 6.4 a en b. 
Tabel 6.4 Impact van ongerief als gevolg van methoden van waterbeperking bij vleeskuikenouderdieren in de opfokperiode (Tabel a) en productieperiode (Tabel b)

Op basis van expert opinie (experts Wageningen Livestock Research) is de ernst, duur en impact van methoden van waterbeperking bij vleeskuikenouderdieren geschat. De spreiding is tussen haakjes weergegeven. De ernst is beoordeeld op een schaal van 1 tot 5 (welzijnsaantasting afwezig (1) tot zeer ernstige welzijnsaantasting (5)), de duur op een schaal van 1-3 (kort-middel-lang). De combinatie van deze scores leidde tot een score voor impact op een schaal van 1-7 (geen impact op het dier tot veel impact op het dier) (Visser et al., 2015).

Tabel 6.4a Opfok

\begin{tabular}{|c|c|c|c|}
\hline $\begin{array}{l}\text { Ongerief als gevolg van verminderde } \\
\text { wateropname door ....... }\end{array}$ & $\begin{array}{l}\text { Ernst } \\
\text { (spreiding) }\end{array}$ & $\begin{array}{l}\text { Duur } \\
\text { (spreiding) }\end{array}$ & Impact \\
\hline Vaste water: voer verhouding & $3(2-3)$ & 3 & 5 \\
\hline $\begin{array}{l}\text { Vast aantal uren water vanaf voeren } \\
\text { (tijdslimiet) }\end{array}$ & 2 & 3 & 4 \\
\hline Verlagen waterdruk & $2(1-2)$ & $3(2-3)$ & 4 \\
\hline \multicolumn{4}{|l|}{ Tabel 6.4b Productie } \\
\hline $\begin{array}{l}\text { Ongerief als gevolg van verminderde } \\
\text { wateropname door ...... }\end{array}$ & $\begin{array}{l}\text { Ernst } \\
\text { (spreiding) }\end{array}$ & Duur & Impact \\
\hline Vaste water: voer verhouding & $3(2-3)$ & $3(2-3)$ & 5 \\
\hline $\begin{array}{l}\text { Vast aantal uren water vanaf voeren } \\
\text { (tijdslimiet) }\end{array}$ & 2 & $3(2-3)$ & 4 \\
\hline Verlagen waterdruk & $2(1-2)$ & 2 & 3 \\
\hline
\end{tabular}

Uit Tabel 6.4 a en b blijkt dat deze expertopinie een iets variabeler beeld geeft dan de expertopinie in Visser et al. (2015). Van de toegepaste methoden in de praktijk om water te beperken wordt het ongerief van een vaste water:voer verhouding het hoogst ingeschat wat betreft de impact; de impact van een vast aantal uren water en een verlaagde waterdruk tijdens de opfokperiode is redelijk en tijdens de productieperiode wordt de impact van een verlaagde waterdruk wat lager ingeschat. Vleeskuikenouderdieren lijken relatief gemakkelijk te wennen aan een beperkte periode van waterverstrekking, waardoor de experts het ongerief als gevolg daarvan minder inschatten dan het ongerief als gevolg van een vaste water:voer verhouding (die meer variabel is met de leeftijd van de vleeskuikenouderdieren). Het feit dat vleeskuikenouderdieren gedurende een flink deel van de dag en gedurende de (nagenoeg) volledige opfok- en productieperiode niet de mogelijkheid hebben om water op te nemen als ze daar behoefte aan hebben heeft geleid tot de inschatting van experts dat er sprake is van een in enige mate aangetast welzijn.

Concluderend kan worden gesteld dat experts inschatten dat waterbeperking in de opfokperiode een impact heeft op het welzijn en dat de impact iets minder is in de productieperiode, maar dat in de productieperiode het risico voor ongerief wel aanwezig is. 


\section{$7 \quad$ Stakeholderconsultatie}

\subsection{Methoden van waterbeperking/gecontroleerd water verstrekken bij vleeskuikens}

Aan de stakeholders is gevraagd om aan te geven of de gebruikte methoden van waterbeperking/gecontroleerd water verstrekken naar hun mening een effect hebben op de diergezondheid, het diergedrag, de productie of de fysiologie van vleeskuikens. Dit betreft dus geen wetenschappelijk onderzoek maar geeft wel weer hoe stakeholders het effect van de methoden van waterverstrekking op de kuikens inschatten. Met name voor het effect op de fysiologie wordt door een aantal stakeholders gezegd dat zij dit niet kunnen aangeven omdat ze daar naar hun mening niet deskundig genoeg voor zijn. De antwoorden van de stakeholders worden samengevat in Tabel 7.1.

Uit Tabel 7.1 blijkt dat over het algemeen de effecten van in de praktijk toegepaste methoden van gecontroleerd water verstrekken aan vleeskuikens op de gezondheid en daardoor op de productie als positief worden gezien, waarbij met name een positief effect op darmgezondheid en de prevalentie van voetzoollaesies wordt genoemd (door het droger houden van het strooisel). Effect op gedrag wordt in het algemeen als gering gezien, zie hiervoor ook de toelichting in de tabel. De meerderheid van de stakeholders merkt op dat de belangrijkste reden om water te beperken is het droog houden van het strooisel, waardoor de kans op het ontstaan van voetzoollaesies wordt beperkt. De resultaten van de stakeholderopinie komen overeen met de expertconsultatie (hoofdstuk 6.1).

Tabel 7.1 Effect van methoden van waterbeperking/gecontroleerde waterverstrekking op diergezondheid, diergedrag, productie en fysiologie van vleeskuikens zoals aangegeven door de geraadpleegde stakeholders. Een lege cel betekent dat de stakeholders geen antwoord hebben gegeven op de vraag. Stakeholders werd gevraagd het effect aan te geven in termen van geen gering - matig - ernstig.

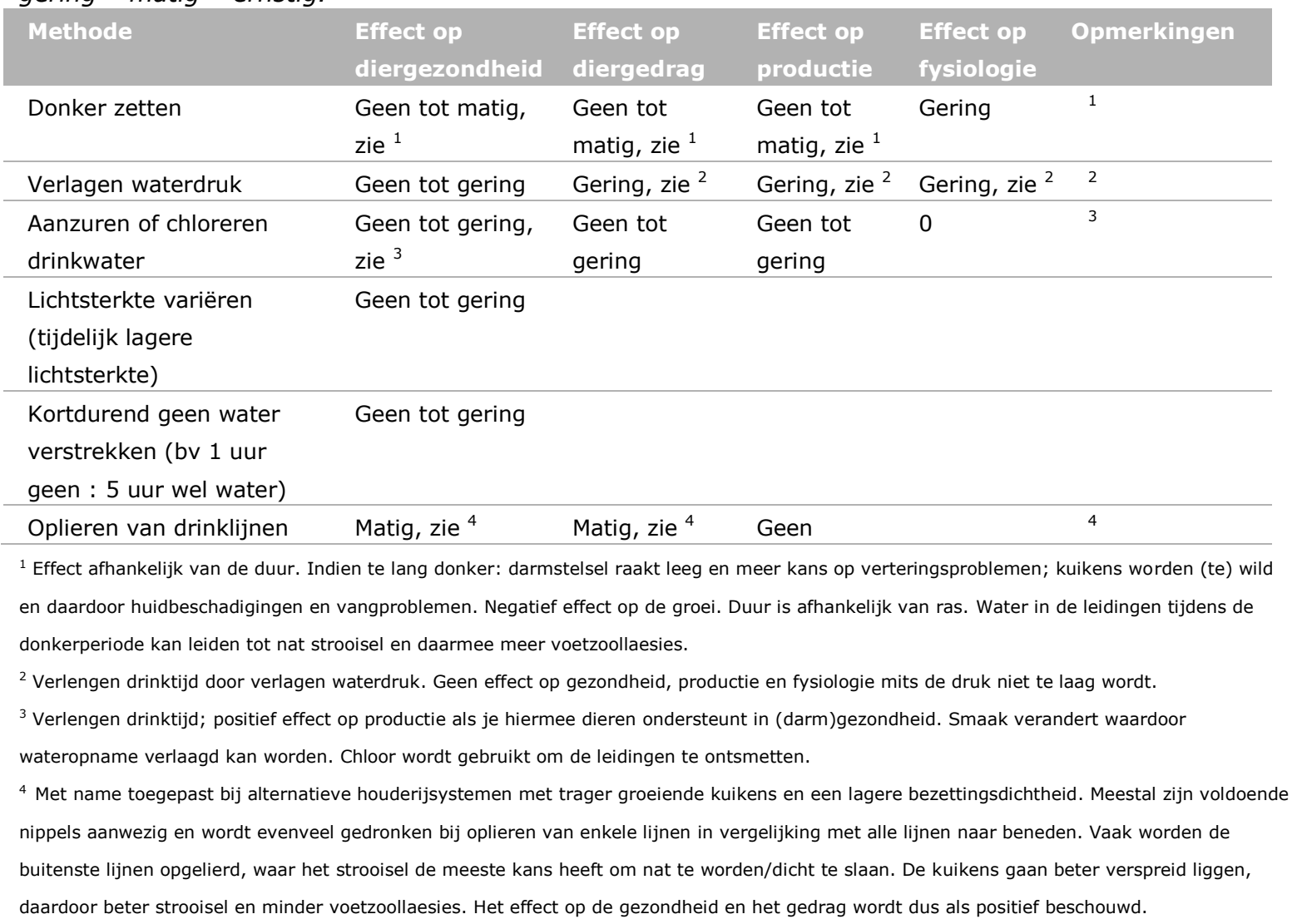




\subsection{Methoden van waterbeperking/gecontroleerd water verstrekken bij vleeskuikenouderdieren}

Ook voor de vleeskuikenouderdieren (opfok en productiefase) is een stakeholderconsultatie uitgevoerd. De resultaten daarvan staan vermeld in Tabel 7.2.

Tabel 7.2 Effect van methoden van waterbeperking op diergezondheid, diergedrag, productie en fysiologie van vleeskuikenouderdieren zoals aangegeven door de geraadpleegde stakeholders. Een lege cel betekent dat de stakeholders geen antwoord hebben gegeven op de vraag. Stakeholders werd gevraagd het effect aan te geven in termen van geen - gering - matig - ernstig.

\begin{tabular}{|c|c|c|c|c|c|}
\hline Methode & $\begin{array}{l}\text { Effect op } \\
\text { diergezondheid }\end{array}$ & $\begin{array}{l}\text { Effect op } \\
\text { diergedrag }\end{array}$ & $\begin{array}{l}\text { Effect op } \\
\text { productie }\end{array}$ & $\begin{array}{l}\text { Effect op } \\
\text { Fysiologie }\end{array}$ & Opmerkingen \\
\hline $\begin{array}{l}\text { Vaste water: voer } \\
\text { verhouding }\end{array}$ & Geen & Geen & Geen & Geen & \\
\hline $\begin{array}{l}\text { Vast aantal uren water } \\
\text { vanaf voeren (tijdslimiet) }\end{array}$ & Geen & Geen & Geen & Geen & 1 \\
\hline Verlagen waterdruk & Geen & Geen & Geen & Geen & 2 \\
\hline
\end{tabular}

Een stakeholder (veterinair) merkt op dat hij bij post-mortem onderzoek bij vleeskuikenouderddieren die water beperkt verstrekt krijgen nog nooit nierafwijkingen, stapeling van urinezuurkristallen e.d. heeft waargenomen (zie 4.3.1), dus dat de gangbare wijze van beperkte waterverstrekking niet lijkt te leiden tot fysiologische afwijkingen of dehydratatie ${ }^{1}$. In het algemeen, onafhankelijk van de methode, werd aangegeven dat bij echt te krappe waterverstrekking de dieren nerveus en onrustig worden en dat te krappe waterverstrekking in de productieperiode leidt tot kleinere eieren. Dit wordt niet aangegeven voor de waterbeperking die standaard wordt toegepast. Voor ouderdieren van trager groeiende kuikens wordt aangegeven dat waterbeperking wordt ingezet om (bij slecht management) de strooiselkwaliteit op peil te houden, maar dat waterbeperking in principe niet of maar zeer beperkt nodig is. Opvallend is dat de resultaten van de stakeholders niet overeenkomen met de resultaten van de expertopinie; de experts schatten in dat beperkte waterverstrekking bij vleeskuikenouderdieren een redelijk tot behoorlijke impact op het welzijn heeft.

Enkele stakeholders geven aan dat onbeperkt water verstrekken aan beperkt gevoerde vleeskuikenouderdieren kan leiden tot overmatig drinken (compensatoir drinkgedrag), vermorsen van water, dunnere darminhoud (natte mest) en slechte strooiselkwaliteit (leidend tot voetzoollaesies en hakdermatitis) en een hogere ammoniakconcentratie in de stal, en in de productieperiode ook tot vuilschalige eieren en een lagere productie. Dit komt deels overeen met de wetenschappelijke literatuur (zie 6.2.2.). Andere stakeholders geven aan dat er geen negatief effect is van onbeperkt water verstrekken bij vleeskuikenouderdieren en dat onbeperkt waterverstrekken leidt tot rustiger dieren, wat mogelijk te maken kan hebben met de foklijn die wordt gebruikt.

Een opmerking die in dat kader ook is gemaakt door een stakeholder is dat de wijze van waterbeperking tijdens de opfokperiode een effect heeft op het gedrag van de dieren in de productieperiode. Koppels die gewend zijn aan onbeperkt water of een lange tijd voor wateropname zijn veel rustiger in hun wateropname in de productieperiode. De wijze van watergift in de opfokperiode beïnvloedt klaarblijkelijk de snelheid van wateropname. In de literatuur wordt dit niet beschreven, wel dat vleeskuikenouderdieren de snelheid van drinken en de opname aanpassen aan het regime waarin het water wordt verstrekt (zie 5.1.6.).

\footnotetext{
${ }^{1}$ Stapeling van urinezuurkristallen op organen, nierafwijkingen e.d. worden wel gezien bij dieren die door kreupelheid of andere oorzaken niet de drinkers kunnen bereiken en daardoor gedehydrateerd zijn.
} 


\subsection{Factoren van invloed op de wateropname}

De stakeholders is gevraagd om uit een lijst van factoren die verondersteld worden van invloed te zijn op de wateropname aan te geven welke factoren zij denken dat van belang zijn, en daarnaast aan te geven wat naar hun mening de meest belangrijke factoren zijn (zie bijlage 2 voor de vragenlijst). Tabel 7.3 en 7.4 geven een samenvatting van de resultaten voor respectievelijk vleeskuikens en vleeskuikenouderdieren. Daarbij hebben de stakeholders ook aangegeven hoe naar hun mening een factor de wateropname beïnvloedt. Dit wordt in tabel 7.3 en 7.4 per factor kort weergegeven. De diverse stakeholders geven daarbij aan dat veel van deze factoren weer met elkaar kunnen interacteren en elkaar dus kunnen remmen of elkaar kunnen versterken.

Als belangrijkste factoren die de wateropname van vleeskuikens beïnvloeden werden genoemd de voersamenstelling, het drinkwatersysteem, ras, geslacht, leeftijd, darmgezondheid en staltemperatuur. Deze factoren, op ras en geslacht na, werden door alle stakeholders genoemd als zijnde van invloed op de wateropname. De waterdruk werd ook door alle stakeholders benoemd als factor van invloed maar scoorde wat lager bij de ranking van factoren.

Bij vleeskuikenouderdieren verschilden de bevraagde stakeholders meer in hun mening dan bij de vleeskuikens; zo werd niet één factor door alle stakeholders benoemd. Meest benoemde factoren van invloed op de wateropname waren voersamenstelling, drinkwatersysteem, waterdruk, reinheid water, geslacht, leeftijd, en darm- of algemene gezondheid. Als meest van belang werden gezien lichtschema, voersamenstelling, drinkwatersysteem, afstand tussen drinkpunten en het ras. Dat komt niet helemaal overeen met het aantal keer dat factoren werden genoemd, wat betekent dat sommige stakeholders een factor als zeer belangrijk zagen en andere (helemaal) niet (zoals lichtschema, afstand tussen drinkpunten, darm- of algemene gezondheid). 
Tabel 7.3 Factoren die mogelijk van invloed zijn op de wateropname van vleeskuikens (eerste kolom) en het aantal keren dat deze benoemd zijn als factor van invloed door de geraadpleegde stakeholders (tweede kolom). In de derde kolom is aangegeven welke factoren gemiddeld hoog eindigen in de 'top tien belangrijkste factoren van invloed op de wateropname', zoals aangegeven door de stakeholders; in de vierde kolom is een korte toelichting gegeven bij de meeste factoren.

\begin{tabular}{|c|c|c|c|}
\hline Factor & $\begin{array}{l}\text { Aantal keer } \\
\text { genoemd } \\
\text { (maximale score } 5 \text { ) }\end{array}$ & $\begin{array}{l}\text { Gemiddelde score } \\
\geq 5 \text { in de top } \\
\text { belangrijkste } \\
\text { factoren }^{1}\end{array}$ & Korte toelichting \\
\hline lichtschema & 3 & & $\begin{array}{l}\text { Meer licht stimuleert de wateropname } \\
\text { Na een lange donkerperiode wordt direct } \\
\text { daarna veel water opgenomen } \\
\text { In het donker wordt niet of nauwelijks } \\
\text { gedronken }\end{array}$ \\
\hline lichtsterkte & 2 & & Meer licht stimuleert de wateropname \\
\hline $\begin{array}{l}\text { soort licht } \\
\text { (daglicht/kunstmatig) }\end{array}$ & 0 & & \\
\hline voersamenstelling & 5 & $\mathrm{x}$ & $\begin{array}{l}\text { K gehalte en ruw eiwitgehalte beïnvloeden } \\
\text { wateropname }\end{array}$ \\
\hline $\begin{array}{l}\text { voerregime } \\
\text { (beperkt/onbeperkt) }\end{array}$ & 2 & & $\begin{array}{l}\text { Effect is beperkt maar als voer op is stoppen ze } \\
\text { met drinken }\end{array}$ \\
\hline bijvoeren hele tarwe & 2 & & Meer tarwe geeft lagere water:voer verhouding \\
\hline strooiseltype & 0 & & \\
\hline drinkwatersysteem & 5 & $\mathrm{x}$ & $\begin{array}{l}\text { Sommige nippels geven meer water dan andere } \\
\text { (type nippel) en de mate waarin de nippel } \\
\text { versleten is beïnvloedt watergift }\end{array}$ \\
\hline $\begin{array}{l}\text { afstand tussen } \\
\text { drinkpunten/waterlijnen }\end{array}$ & 3 & & $\begin{array}{l}\text { Grotere afstand beperkt de opname } \\
\text { Is rasafhankelijk }\end{array}$ \\
\hline waterdruk & 5 & & Lagere druk, langere opname \\
\hline reinheid water & 2 & & $\begin{array}{l}\text { Smaak beïnvloedt opname, hiermee kan je de } \\
\text { opname sturen }\end{array}$ \\
\hline additieven in drinkwater & 5 & $\mathrm{x}$ & $\begin{array}{l}\text { Smaak beïnvloedt opname, hiermee kan je de } \\
\text { opname sturen }\end{array}$ \\
\hline ras/merk & 4 & $\mathrm{x}$ & $\begin{array}{l}\text { Trager groeiende kuikens drinken minder dan } \\
\text { gangbare kuikens }\end{array}$ \\
\hline geslacht & 4 & $\mathrm{x}$ & $\begin{array}{l}\text { Hanen drinken meer dan hennen (of hanen zijn } \\
\text { zwaarder op eenzelfde leeftijd en drinken } \\
\text { daarom meer) }\end{array}$ \\
\hline leeftijd & 5 & $\mathrm{x}$ & Oude kuikens drinken meer dan jonge \\
\hline darmgezondheid & 5 & $\mathrm{x}$ & $\begin{array}{l}\text { Zieke kuikens drinken minder of niet } \\
\text { Darmstoornissen beïnvloeden de resorptie van } \\
\text { water door de darm }\end{array}$ \\
\hline ventilatiedebiet & 1 & & Bij tocht minder drinken \\
\hline wijze van ventileren & 1 & & Bij tocht minder drinken \\
\hline temperatuurschema & 3 & & Te hoog, meer opname \\
\hline werkelijke staltemperatuur & 5 & $\mathrm{x}$ & Te hoog, meer opname \\
\hline relatieve luchtvochtigheid & 2 & & Te hoog, meer opname \\
\hline stofconcentratie & 1 & & Irritatie slijmvliezen verhoogt wateropname \\
\hline ammoniakconcentratie & 0 & & \\
\hline mobiliteit kuikens & 1 & & Kuikens met betere mobiliteit drinken meer \\
\hline luchtweggezondheid & 4 & & $\begin{array}{l}\text { Over het algemeen drinkt een ziek koppel } \\
\text { evenveel (met lagere voeropname) of minder of } \\
\text { niet }\end{array}$ \\
\hline $\begin{array}{l}\text { gezondheid/vitaliteit koppel } \\
\text { algemeen }\end{array}$ & 4 & & $\begin{array}{l}\text { Over het algemeen drinkt een ziek koppel } \\
\text { evenveel (met lagere voeropname) of minder of } \\
\text { niet }\end{array}$ \\
\hline antibiotica toediening & 4 & & $\begin{array}{l}\text { Als ze zich weer fit voelen nemen ze kortdurend } \\
\text { meer water op }\end{array}$ \\
\hline vaccinatietoediening & 2 & & $\begin{array}{l}\text { Reactie na enting, van te voren geen } \\
\text { watertoediening i.v.m. goede opname entstof }\end{array}$ \\
\hline vaccinatieschema & 2 & & Idem als hierboven \\
\hline $\begin{array}{l}\text { uitkomstmethode } \\
\text { (broederij/stal/hatchbrood) }\end{array}$ & 0 & & Alleen de eerste $2-3$ dagen een effect \\
\hline afleidingsmateriaal & 0 & & Geen effect zichtbaar van stro of luzerne \\
\hline emissiearm stalsysteem & 0 & & \\
\hline bezettingsdichtheid & 1 & & $\begin{array}{l}\text { Bij hoge bezetting komen de kuikens } \\
\text { moeilijker bij de nippel }\end{array}$ \\
\hline
\end{tabular}


Tabel 7.4 Factoren die mogelijk van invloed zijn op de wateropname van vleeskuikenouderdieren (eerste kolom) en het aantal keren dat deze benoemd zijn als factor van invloed door de geraadpleegde stakeholders (tweede kolom). In de derde kolom is aangegeven welke factoren gemiddeld hoog eindigen in de 'top tien belangrijkste factoren van invloed op de wateropname', zoals aangegeven door de stakeholders; in de vierde kolom is een korte toelichting gegeven bij de meeste factoren.

\begin{tabular}{|c|c|c|c|}
\hline Factor & $\begin{array}{l}\text { Aantal keer } \\
\text { genoemd } \\
\text { (maximale } \\
\text { score } 4 \text { ) }\end{array}$ & $\begin{array}{l}\text { Gemiddelde score } \\
\geq 5 \text { in de top } \\
\text { belangrijkste } \\
\text { factoren }^{1}\end{array}$ & Korte toelichting \\
\hline lichtschema & 2 & $x$ & $\begin{array}{l}\text { Bij meer uren licht kan de water en } \\
\text { voeropname stijgen }\end{array}$ \\
\hline lichtsterkte & 1 & & \\
\hline $\begin{array}{l}\text { soort licht } \\
\text { (daglicht/kunstmatig) }\end{array}$ & 0 & & \\
\hline voersamenstelling & 3 & $x$ & \\
\hline $\begin{array}{l}\text { voerregime } \\
\text { (beperkt/onbeperkt) }\end{array}$ & 3 & & $\begin{array}{l}\text { Moederdieren van trager groeiende } \\
\text { vleeskuikens worden niet of nauwelijks beperkt } \\
\text { in voeropname }\end{array}$ \\
\hline bijvoeren hele tarwe & 1 & & \\
\hline strooiseltype & 0 & & $\begin{array}{l}\text { Hanen pikken soms strooisel op en nemen dan } \\
\text { meer water op }\end{array}$ \\
\hline drinkwatersysteem & 3 & $x$ & $\begin{array}{l}\text { Groot verschil tussen nippel/ronddrinker, } \\
\text { hogere opname uit open systeem } \\
\text { (vermorsing), slechte afstelling meer } \\
\text { vermorsing }\end{array}$ \\
\hline $\begin{array}{l}\text { afstand tussen } \\
\text { drinkpunten/waterlijnen }\end{array}$ & 2 & $x$ & \\
\hline waterdruk & 3 & & Lagere druk, lagere opname \\
\hline reinheid water & 3 & & $\begin{array}{l}\text { Is i.h.a. goed in orde } \\
\text { Lagere wateropname bij vervuild water } \\
\text { (afwijkende smaak), komt niet meer voor }\end{array}$ \\
\hline additieven in drinkwater & 3 & & $\begin{array}{l}\text { Additieven kunnen wateropname stimuleren of } \\
\text { remmen (afwijkende smaak) }\end{array}$ \\
\hline ras/merk & 2 & $x$ & \\
\hline geslacht & 3 & & $\begin{array}{l}\text { Waterverbruik hanen veel hoger } \\
\text { Hanen spelen meer met water tijdens de opfok }\end{array}$ \\
\hline leeftijd & 3 & & \\
\hline darmgezondheid & 3 & & $\begin{array}{l}\text { Kan positief en negatief effect hebben op de } \\
\text { wateropname }\end{array}$ \\
\hline ventilatiedebiet & 0 & & \\
\hline wijze van ventileren & 0 & & Indirecte effecten op klimaat \\
\hline temperatuurschema & 0 & & \\
\hline werkelijke staltemperatuur & 2 & & $\begin{array}{l}\text { Hogere temperatuur, hogere opname } \\
\text { Zomers hogere wateropname }\end{array}$ \\
\hline relatieve luchtvochtigheid & 1 & & \\
\hline stofconcentratie & 0 & & \\
\hline ammoniakconcentratie & 0 & & \\
\hline mobiliteit dieren & 0 & & Heeft ook veel te maken met gezondheid \\
\hline luchtweggezondheid & 1 & & \\
\hline $\begin{array}{l}\text { gezondheid/vitaliteit koppel } \\
\text { algemeen }\end{array}$ & 3 & & $\begin{array}{l}\text { Ziektes beïnvloeden de wateropname (meestal } \\
\text { minder wateropname) }\end{array}$ \\
\hline antibiotica toediening & 2 & & Kan positief of negatief effect hebben \\
\hline vaccinatietoediening & 2 & & $\begin{array}{l}\text { Na emulsie enting tijdelijke daling } \\
\text { wateropname } \\
\text { Entreactie (bv. ILT) tijdelijke daling } \\
\text { wateropname }\end{array}$ \\
\hline vaccinatieschema & 0 & & \\
\hline $\begin{array}{l}\text { uitkomstmethode } \\
\text { (broederij/stal/hatchbrood) }\end{array}$ & 0 & & \\
\hline afleidingsmateriaal & 2 & & $\begin{array}{l}\text { Afleidingsmateriaal met ruwe celstof (luzerne } \\
\text { e.d.) stimuleren wateropname }+\end{array}$ \\
\hline emissiearm stalsysteem & 0 & & \\
\hline
\end{tabular}

${ }^{1}$ Hiervoor is de score in de top-10 gegeven door de diverse experts gemiddeld en is gekeken naar factoren die tenminste door twee experts worden benoemd als zijnde van invloed. Daardoor worden meer dan vijf factoren in deze lijst weergegeven. 


\title{
$8 \quad$ Discussie en mogelijke maatregelen
}

\subsection{Ongerief door beperkte waterverstrekking aan vleeskuikens}

\begin{abstract}
Alhoewel in de praktijk vleeskuikens meestal niet in hun waterconsumptie worden beperkt in de strikte zin van het woord, door het dichtzetten van de waterkraan gedurende één of meerdere langere perioden op een dag, wordt de watergift op een groot deel (maar niet alle bedrijven) wel gecontroleerd. Dit gebeurt door het nemen van managementmaatregelen, zoals het verlagen van de lichtintensiteit, oplieren van drinklijnen, het invoeren van een korte donkerperiode, het verminderen van de waterdruk of het toevoegen van drinkwateradditieven ${ }^{2}$ die de wateropname beperken. Wanneer de kraan wel wordt dichtgezet is dit altijd maar gedurende een korte periode op een dag (wanneer dit in de lichtperiode wordt gedaan). Daarnaast zijn er bedrijven die gedurende een groot deel van de donkerperiode de watertoevoer afsluiten. Het water is dan wel voor een langere periode afgesloten, maar dit zou geen impact hebben op het welzijn en omdat kuikens in de donkerperiode geen water opnemen. Experts schatten in dat deze methoden geen impact hebben op het welzijn van vleeskuikens omdat er naar hun inschatting geen sprake is van ongerief door dorst of stress vanwege het feit dat vleeskuikens nog steeds voldoende water op kunnen nemen.
\end{abstract}

Een belangrijke reden voor het feit dat er bij vleeskuikens meestal geen waterbeperking in de strikte zin van het woord plaatsvindt is dat bij waterbeperking er een negatief effect zal zijn op de voeropname (Butterworth, et al., 2002; Lott et al., 2003), en dus op de groei van de kuikens en uiteindelijk de financiële opbrengst van een koppel. Ook vormt dit een risico voor uitval op warme dagen. Het lijkt dus niet waarschijnlijk dat er in de praktijk sprake is van ongerief door de toegepaste gecontroleerde waterverstrekking.

Er zijn geen wetenschappelijke publicaties over het effect van de diverse methoden van gecontroleerde waterverstrekking zoals toegepast onder Nederlandse praktijkomstandigheden op het welzijn van vleeskuikens. Het is daarom aan te bevelen om hier verder onderzoek naar uit te voeren, om vast te stellen of er daadwerkelijk geen sprake is van ongerief en/of dat er mogelijke verschillen zijn in ongerief tussen de toegepaste methoden in de praktijk.

In de praktijk wordt de waterverstrekking gecontroleerd om vermorsing of een te hoge opname te voorkomen, zodat de strooiselkwaliteit goed blijft en er minder risico is op het ontstaan van welzijnsproblemen door te nat strooisel (o.a. respiratoire aandoeningen en contact dermatitis) (o.a., De Jong et al., 2012; Vanderhasselt, 2013), daarnaast bevordert droog en rul strooisel natuurlijk gedrag, zoals scharrelen en stofbaden (Shields et al., 2004). Daarbij is er altijd sprake van een balans tussen het kunnen opnemen van voldoende water voor optimale groei van de vleeskuikens en het voorkomen van de negatieve effecten van nat strooisel.

Daarnaast geldt voor alle maatregelen die nu worden genomen dat er altijd een optimum is; wanneer de donkerperiode te lang duurt, er te veel drinklijnen zijn opgelierd en/of de waterdruk te laag is, zal er stress ontstaan bij de kuikens en/of competitie bij het drinken. Waar deze grenzen liggen voor de verschillende maatregelen is niet beschreven in de literatuur. Daarnaast zijn er situaties waarbij er geen sprake is van ongerief doordat kuikens niet tegelijk kunnen gaan drinken (sociale facilitatie speelt een rol bij drinken (Franchina et al., 1986; Hoppitt and laland, 2009)) en/of competitie bij de drinkwatervoorziening. Het is daarom van belang dat er valide en praktisch haalbare indicatoren zijn voor dorst die kunnen worden toegepast wanneer er mogelijk sprake kan zijn van een situatie waarin

\footnotetext{
2 Drinkwateradditieven worden niet primair ingezet om de wateropname te beperken maar om de darmgezondheid te bevorderen. Ze hebben echter, door het verlagen van de $\mathrm{pH}$ wel een direct effect op de waterconsumptie (Van Harn, pers. med.; Van Harn en de Jong, 2014).
} 
het welzijn onder druk staat. Deze indicatoren zijn benoemd in paragraaf 4.3.5., waarbij ook is aangegeven dat verder onderzoek naar praktisch haalbare indicatoren van belang is. Gesuggereerd wordt dat wanneer er sprake is van waterbeperking er sprake zou zijn van onrust en agressief gedrag bij vleeskuikens (Viola et al., 2009). Deze gedragingen kunnen dus mogelijk indicatief zijn voor inadequaat watermanagement, maar daarvoor is meer onderbouwing nodig door middel van onderzoek. Dit geldt ook voor indicatoren die aan kunnen geven of belemmering van synchronisatie van drinkgedrag mogelijk ongerief veroorzaakt.

Bovenstaande geldt wanneer naar het hele koppel in de stal wordt gekeken en geldt niet voor vleeskuikens die door ziekte, kreupelheid of achterblijvend lichaamsgewicht niet bij de drinknippel kunnen komen (Butterworth et al., 2002). In principe moeten deze kuikens door selectie uit het koppel verwijderd worden om verder lijden te voorkomen; bij locomotie geldt dit voor kuikens met een gait score ${ }^{3}$ van 4 en 5 (Butterworth et al., 2002). Indien dat niet het geval is dan zullen deze kuikens afgekeurd worden aan de slachtlijn. Een hoog percentage afkeur aan de slachtlijn door vermagering zou daarom mede indicatief kunnen zijn voor chronische dorst (De Jong et al., 2015).

\subsubsection{Randvoorwaarden ter voorkoming van ongerief door beperkte waterverstrekking aan vleeskuikens}

Op basis van de huidige expertkennis en wetenschappelijke publicaties is er geen aanleiding om aan te nemen dat er sprake is van ongerief door de gecontroleerde waterverstrekking aan vleeskuikens, mits aan een aantal randvoorwaarden wordt voldaan om het risico op ongerief zo beperkt mogelijk te houden:

- $\quad$ De drinknippels (of andere typen drinkers) moeten gemakkelijk bereikbaar zijn, dus bijvoorbeeld de afstand tot de drinkwatervoorziening mag niet belemmerend zijn, dit aspect is met name van belang bij een hoge bezettingsdichtheid (Feddes et al., 2002, 2003);

- $\quad$ Er moeten voldoende drinknippels (of andere typen drinkers) beschikbaar zijn om competitie aan de nippel te voorkomen op het moment dat veel kuikens willen gaan drinken, bijvoorbeeld wanneer het licht aangaat;

- $\quad$ De drinklijnen moeten op de juiste hoogte hangen om enerzijds te voorkomen dat kuikens niet bij de nippel/drinker kunnen en anderzijds te voorkomen dat er teveel vermorsing plaats vindt waardoor nat strooisel ontstaat (wat een risico geeft op welzijnsproblemen).

In de wetenschappelijke literatuur is niet te vinden wat de eisen zijn ten aanzien van maximale afstand, hoogte, of aantal kuikens per drinkwaterpunt. Deze getallen worden wel genoemd in brochures en managementgidsen (o.a., Aviagen 20141,b; IKB 2016; De Gussem, 2014).

\subsection{Vleeskuikenouderdieren}

Bij nagenoeg alle vleeskuikenouderdierbedrijven wordt waterbeperking toegepast en door experts wordt ingeschat dat dit een redelijke tot behoorlijke impact kan hebben op het welzijn van de vleeskuikenouderdieren. Echter, de onderbouwing hiervoor in de wetenschappelijke literatuur is afwezig. Zo geven Hocking et al. (1993) aan dat er geen aanwijzingen zijn, op basis van fysiologische en gedragsindicatoren, dat waterbeperking leidt tot verminderd welzijn bij vleeskuikenouderdieren. Overige wetenschappelijke publicaties met betrekking tot het effect van beperkte waterverstrekking aan vleeskuikenouderdieren op welzijn zijn niet gevonden. Daarnaast zijn er aanwijzingen dat vleeskuikenouderdieren lijken te wennen aan waterbeperking wanneer water alleen maar beschikbaar is gedurende een beperkt aantal uren op een dag (Ross et al., 1981).

\footnotetext{
${ }^{3}$ De gait score wordt gebruikt om de kwaliteit van de locomotie van een vleeskuiken te beoordelen. Een gait score 4 betekent dat een kuiken zeer slecht kan lopen, een gait score 5 betekent dat een kuiken niet meer kan lopen (Welfare Quality, 2009).
} 
Uit de literatuur blijkt dat onbeperkte waterverstrekking aan beperkt gevoerde vleeskuikenouderdieren niet noodzakelijkerwijs leidt tot overmatige waterconsumptie, maar dat er wel mogelijk meer sprake kan zijn van vermorsing van water (Hocking et al., 1993, 1996; Jones et al., 2004). Alhoewel relatief oude literatuur spreekt over 'overdrinking (polydipsia)' bij beperkt gevoerde vleeskuikenouderdieren met onbeperkte waterverstrekking (Kostal et al., 1992) zijn hier geen aanwijzingen voor in meer recente literatuur (Jones et al., 2004). Stakeholders geven ook aan dat niet in alle landen de watergift wordt beperkt en dat het mogelijk is om onbeperkt water te verstrekken aan beperkt gevoerde vleeskuikenouderdieren. De noodzaak tot beperkte waterverstrekking aan vleeskuikenouderdieren lijkt daarmee afwezig, maar adequaat strooiselmanagement is noodzakelijk om eventuele negatieve gevolgen van vermorsing (contact dermatitis, respiratoire aandoeningen, beperking van natuurlijk gedrag (o.a. Shepherd and Fairchild, 2010; Shields et al., 2004; Vanderhasselt, 2014) te beperken.

\subsubsection{Maatregelen ter voorkoming van ongerief door beperkte waterverstrekking aan vleeskuikenouderdieren}

Op basis van wetenschappelijke publicaties is er geen aanleiding om aan te nemen dat er sprake is van ongerief door beperkte waterverstrekking aan vleeskuikenouderdieren, maar door experts wordt aangegeven dat er mogelijk wel sprake is van impact op het welzijn onder Nederlandse omstandigheden. Maatregelen die genomen kunnen worden om het risico op ongerief zo beperkt mogelijk te houden zijn:

- Onbeperkt water verstrekken aan vleeskuikenouderdieren, waarbij adequaat strooiselmanagement mogelijk noodzakelijk is om negatieve effecten van nat strooisel door hogere wateropname of vermorsing te beperken;

- Inzetten van ouderdieren van trager groeiende vleeskuikenrassen (zoals dwergmoederdieren). Deze hoeven niet in hun voeropname beperkt te worden en laten geen stereotiep pikgedrag naar de drinknippel zien. Er is bij deze vleeskuikenouderdieren daarom geen noodzaak om waterbeperking toe te passen;

- Toepassen van een verdund voer waardoor vleeskuikenouderdieren minder stereotiep pikgedrag naar de drinker laten zien en mogelijk ook minder 'overconsumptie' van water (o.a. Nielsen et al., 2011; De Jong et al., 2005; D' Eath et al., 2009). Ondanks dat er relatief veel onderzoek naar alternatieve voeders is uitgevoerd worden deze in de praktijk nog niet grootschalig toegepast omdat er nog verdere verfijning moet plaatsvinden (o.a. De Jong and Guemené, 2011);

- Wanneer beperkte waterverstrekking wordt toegepast, kiezen voor een vast aantal uren water op een dag in plaats van een vaste water:voer verhouding. Experts schatten in dat een vast aantal uren water per dag een lagere impact heeft op het welzijn dan een vaste water:voer verhouding, mogelijk doordat vleeskuikenouderdieren gemakkelijker aan het regime kunnen wennen. Een ander mogelijk alternatief is het verlagen van de waterdruk, wat bij vleeskuikenouderdieren niet veel wordt toegepast en waarvan het effect op het welzijn, op basis van literatuur, niet bekend is, maar waarvan de impact volgens experts lager is dan een vaste water:voer verhouding toepassen;

- Wanneer beperkte waterverstrekking wordt toegepast gelden in principe dezelfde aanvullende maatregelen als bij vleeskuikens om het ongerief als gevolg van beperking van synchronisatie van drinkgedrag en/of competitie bij het drinkpunt te beperken: drinkpunten moeten gemakkelijk bereikbaar zijn, er moeten voldoende drinkpunten beschikbaar zijn en de drinklijnen moeten op de juiste hoogte hangen. Net als voor vleeskuikens geldt voor vleeskuikenouderdieren dat een wetenschappelijke onderbouwing voor normen ontbreekt maar normen wel te vinden zijn in managementgidsen en voorlichtingsbrochures ( $0 . a$. Aviagen 2014a, Cobb, 2008). 


\section{$9 \quad$ Conclusies en aanbevelingen}

\subsection{Vleeskuikens}

In de huidige praktijk worden vleeskuikens meestal niet beperkt in hun waterconsumptie. Er zijn echter bedrijven die het water gecontroleerd verstrekken aan de vleeskuikens. Gecontroleerd verstrekken van water houdt in dat overmatige consumptie of vermorsing van water wordt voorkomen door het toepassen van maatregelen, zoals het donker zetten van kuikens, reduceren van de lichtintensiteit, verlagen van de waterdruk of toevoegen van additieven, maar niet via het langdurig dichtdraaien van de kraan. Op basis van literatuur en expertopinies wordt ingeschat dat deze maatregelen geen impact hebben op het welzijn van de kuikens.

Wetenschappelijke studies ter onderbouwing van deze conclusie ontbreken echter grotendeels en de volgende aanbevelingen worden daarom gedaan voor verder onderzoek:

- Onderzoek naar praktisch haalbare en valide indicatoren voor het meten van dorst bij vleeskuikens;

- Onderzoek naar praktisch haalbare en valide indicatoren voor het meten van ongerief door waterbeperking/gecontroleerde waterverstrekking, zoals indicatoren voor competitie aan de drinkwatervoorziening. Hier is nog geen sprake van dorst maar wel van mogelijk ongerief door bijvoorbeeld een fysieke beperking om synchroon te kunnen drinken;

- Onderzoek naar het effect van de diverse methoden van gecontroleerde waterverstrekking zoals toegepast in Nederland op het welzijn van vleeskuikens. Dit om vast te stellen of er daadwerkelijk geen sprake is van ongerief en/of dat er mogelijke verschillen zijn in ongerief tussen de toegepaste methoden in de praktijk, en de grenzen vast te stellen waarbij het welzijn niet wordt geschaad;

- Verder onderzoek naar factoren die van invloed zijn op de waterconsumptie. Voor een groot aantal factoren in het rapport beschreven is de onderbouwing vanuit de wetenschappelijke literatuur erg mager of gedateerd. Inzicht in factoren van invloed op waterconsumptie vergroot het inzicht in het effect van watermanagement op het welzijn van vleeskuikens. Daarnaast zijn er momenteel veel ontwikkelingen naar alternatieve houderijsystemen, vaak in combinatie met andere rassen (merken), terwijl onbekend is of er andere eisen gesteld moeten worden aan het watermanagement in deze nieuwe houderijsystemen.

\subsection{Vleeskuikenouderdieren}

In de huidige praktijk wordt water meestal beperkt verstrekt aan vleeskuikenouderdieren, om een te hoge wateropname of vermorsing en het negatieve effect daarvan op dierenwelzijn te voorkomen. Uit de wetenschappelijke literatuur komt echter naar voren dat onbeperkte waterverstrekking waarschijnlijk geen risico voor het welzijn vormt, mits adequaat management wordt toegepast om de strooiselkwaliteit op peil te houden.

Anderzijds zijn er op basis van wetenschappelijke literatuur geen aanwijzingen dat waterbeperking door middel van een vast aantal uren water verstrekken per dag een negatief effect op het welzijn van vleeskuikenouderdieren heeft, dit is echter maar gebaseerd op een enkele studie. Experts schatten dat de in de praktijk toegepaste waterbeperking bij vleeskuikenouderdieren wel een negatieve impact op het welzijn heeft. Er is daarom behoefte aan meer inzicht in de effecten van beperkte en onbeperkte waterverstrekking aan vleeskuikenouderdieren.

De volgende aanbevelingen worden gedaan voor verder onderzoek:

- Verder onderzoek naar het effect van het beperkt waterverstrekken aan vleeskuikenouderdieren op het welzijn van het huidige vleeskuikenouderdier zoals gehouden in Nederland. Er is maar zeer beperkt en relatief oude literatuur aanwezig over dit onderwerp, 
en zowel het management als de genetische achtergrond van het vleeskuikenouderdier zijn sterk veranderd in de afgelopen 20 jaar (o.a. Zuidhof et al., 2014);

- Verder onderzoek naar het effect van onbeperkte waterverstrekking aan vleeskuikenouderdieren op het welzijn. De verwachting is dat het welzijn niet negatief wordt beïnvloed maar onderbouwing hiervoor op basis van wetenschappelijke literatuur is beperkt;

- Analoog aan de aanbevelingen voor vleeskuikens is verder onderzoek naar factoren die van invloed zijn op de waterconsumptie van belang omdat voor een groot aantal mogelijke invloedsfactoren wetenschappelijke onderbouwing ontbreekt. Inzicht in factoren van invloed op waterconsumptie vergroot het inzicht in het effect van watermanagement op het welzijn van vleeskuikenouderdieren;

- Analoog aan de aanbevelingen voor vleeskuikens is verder onderzoek naar praktisch valide en haalbare indicatoren voor het meten van dorst en ongerief door waterbeperking bij vleeskuikenouderdieren noodzakelijk. 


\section{Literatuur}

Abdelsamie, R.E., and Yadiwilo, F. (1981). Water Consumption And The Effects Of Water Restriction On Performance Of Broilers In The Tropics. British Poultry Science 22, 423-429.

ACP (2006). Assured Chicken Production Standards 2005-2006. http://services.1kiwa.com/library/services-kiwa-couk/files/RedTractor_Chicken_Application_Form.pdf

Ag_Guide (2010). Poultry. In: Guide for the Care and Use of Agricultural Animals in Research and Teaching (Ag Guide). Third ed: (c) Federation of Animal Science Societies, 2010.

Ahmad, T., and Sarwar, M. (2006). Dietary electrolyte balance: Implications in heat stressed broilers. World's Poultry Science Journal 62, 638-653.

Algers, B., R. Westin (2009). Assesment of water and food deprivation in poultry. In: Welfare Quality Reports 9, Assessment of animal welfare measures for layers and broilers.

Arscott, G.H. (1969). Effect of Varying Periods of Water Restriction at Different Ages in Broiler Chickens. Poultry Science 48, 731-\&.

Arad, Z., S.S. Arnason, A. Chadwick, and E. Skadhauge. (1985). Osmotic and hormonal responses to heat and dehydration in the fowl. J. Comp. Physiol. B 155:227-234

Aviagen (2014a) Ross broiler handbook. http://en.aviagen.com/assets/Tech_Center/Ross_Broiler/Ross-Broiler-Handbook-2014i-EN.pdf

Aviagen (2014b). Ross performance objectives. http://en.aviagen.com/assets/Tech_Center/Ross_Broiler/Ross-308-Broiler-PO-2014-EN.pdf

Aviagen (2013). Ross 308 PS management guide http://en.aviagen.com/assets/Tech_Center/Ross_PS/Ross_PS_Handbook_2013_i-r1.pdf

Baghbanzadeh, A., M.R. Hajinezhad, B. Shohreh, and R. Maleklou. (2010). Intralateral hypothalamic area injection of isoproterenol and proponolol affects food and water intake in broilers. J. Comp. Physiol. A. Neuroethol. Sens. Neural Behav. Physiol. 196:221-226.

Barton, T.L. (1996). Relevance of water quality to broiler and turkey performance. Poultry Science 75 , 854-856.

Batal, A., Fairchild, B., Ritz, C., and Vendrell, P. (2005a). The effect of water manganese on broiler growth performance. Poultry Science 84, 13-14.

Batal, A.B., Fairchild, B.D., W., R.C., and F., V.P. (2005b). The effect of water manganese on broiler growth performance. Poultry Science. 84 (Suppl. 1.), 13-14.

Baeumer, E. 1955. Lebensart des Haushuhns. Zeitschrift für Tierpsychologie 12:387-401.

Beg, M.a.H., Baqui, M.A., Sarker, N.R., and Hossain, M.M. (2011). Effect of stocking density and feeding regime on performance of broiler chicken in summer season. International Journal of Poultry Science 10, 365-375.

Belay, T., Bartels, K.E., Wiernusz, C.J., and Teeter, R.G. (1993). A Detailed Colostomy Procedure and Its Application to Quantify Water and Nitrogen-Balance and Urine Contribution to Thermobalance in Broilers Exposed to Thermoneutral and Heat-Distressed Environments. Poultry Science 72, 106115.

Belay, T., and Teeter, R.G. (1993). Broiler Water-Balance and Thermobalance during Thermoneutral and High Ambient-Temperature Exposure. Poultry Science 72, 116-124.

Bell, D.B. (2002). Consumption and quality of water, in Commercial Chicken Meat and Egg Production, eds. D.D. Bell \& W.D. Weaver. (Norwell, MA.: Kluwer Academic Publishers), 411-430.

Bennett, C.D., and Leeson, S. (1989). Water usage of broiler breeders. Poultry Science 68, 617-621.

Besluit Houders van Dieren (2014). https://zoek.officielebekendmakingen.nl/stb-2014-210.html

Bestman, M., and C. Keppler. (2005). Jong geleerd is oud gedaan. Opfok van leghennen voor alternative systemen [Rearing pullets for alternative systems]. Louis Bolk Instituut Publication number LV-55.

Bestman, M. W. P., M. A. W. Ruis, K. Middelkoop, and J. Heijmans. 2011. Kipsignalen : praktijkgids voor diergericht pluimvee, tweede herziene druk. Roodbont Publishers BV, Zutphen. 
Borges, S.A., Fischer Da Silva, A.V., Maiorka, A., Hooge, D.M., and Cummings, K.R. (2004). Effects of diet and cyclic daily heat stress on electrolyte, nitrogen and water intake, excretion and retention by colostomized male broiler chickens. International Journal of Poultry Science 3, 313-321.

Branton, S.L., Simmons, J.D., Lott, B.D., Miles, D.M., and Maslin, W.R. (2001). Chick mortality associated with elevated water lines and consumption of wet litter. Journal of Applied Poultry Research 10, 427-430.

Braun, E.J. (2015). Osmoregulatory systems of birds. In: Sturkie's Avian Physiology. Ed. C.G. Scanes. Academic Press, San Diego, USA, pp. 285-300.

Bruno, L.D.G., Maiorka, A., Macari, M., Furlan, R.L., and Givisiez, P.E.N. (2011). Water intake behavior of broiler chickens exposed to heat stress and drinking from bell or and nipple drinkers. Revista Brasileira de Ciencia Avicola 13, 147-152.

Butcher, G.D., Jacob, J.P., and Mather, F.B. (1999). Common Poultry Diseases, in: Fact Sheet PS-47 (University of Florida).

Butterworth, A. (1999). Infectious components of broiler lameness: a review. Worlds Poultry Science Journal 55, 327-352.

Butterworth, A. (2013). On-farm broiler welfare assessment and associated training. Revista Brasileira de Ciencia Avicola 15, 71-77.

Butterworth, A., Weeks, C.A., Crea, P.R., and Kestin, S.C. (2002). Dehydration and lameness in a broiler flock. Animal Welfare 11, 89-94.

Carter, T.A., and Sneed, R.E. (1987). Drinking water quality for poultry. North Carolina State University, Raleigh, NC.: PS\&T Guide No. 42, Extension Poultry Science.

Castro, E.E.C., Penz, A.M., Ribeiro, A.M.L., and Sbrissia, A.F. (2009). Effect of water restriction and sodium levels in the drinking water on broiler performance during the first week of life. Revista Brasileira De Zootecnia-Brazilian Journal of Animal Science 38, 2167-2173.

Cengiz, O., J. B. Hess, and S. F. Bilgili. 2012. Influence of graded levels of dietary sodium on the development of footpad dermatitis in broiler chickens. Journal of Applied Poultry Research 21:770775. doi 10.3382/japr.2011-00464

Chikumba, N., and Chimonyo, M. (2014). Effects of Water Restriction on the Growth Performance, Carcass Characteristics and Organ Weights of Naked Neck and Ovambo Chickens of Southern Africa. Asian-Australasian Journal of Animal Sciences 27, 974-980.

CIWF (2013). Welfare Sheet: Broiler chickens, in: Farm Animal Welfare Compendium Updated 01.05.2013. (ed.) C.T.U. Kingdome.

Cobb (2008). Breeder Management Guide. http://www.cobb-vantress.com/docs/default-source/oldguides---management-guides/cobb-breeder-management-guide--english9572C08ABE83EB4B84177B12.pdf?sfvrsn=2.pdf

Collett, S.R. (2012). Nutrition and wet litter problems in poultry. Anim. Feed Sci. Technol. 173: 65-75.

Colvero, L.P., Carrijo, A.S., Garófallo, R.G., Bernardi, R., Steffen, R.P.B., and Stefanello, C. (2014). Production aspects of broiler breeders submitted to different drinker types. Revista Brasileira de Ciencia Avicola 16, 61-65.

Cornelison, J.M., Hancock, A.G., Williams, A.G., Davis, L.B., and Watkins, S.E. (2006). Evaluation of nipple drinkers and the Lott System for determining appropriate water flow for broilers. Poultry Science 85, 170-170.

D'Eath, R.B., Tolkamp, B.J., Kyriazakis, I., and Lawrence, A.B. (2009). 'Freedom from hunger' and preventing obesity: the animal welfare implications of reducing food quantity or quality. Animal Behaviour 77, 275-288.

De Jong, I., Berg, C., Butterworth, A., and Estevéz, I. (2012). Scientific report updating the EFSA opinions on the welfare of broilers and broiler breeders. EFSA Journal 6, 10.2903/sp.efsa.2012.EN295

De Jong, I.C., Butterworth, A., Tuyttens, F.A.M., Buijs, S. (2015). Suggestions for modifications of the WQ broiler chicken welfare assessment protocol. Abstract of the Welfare Quality Network meeting, Barcelona, December 2016.

De Jong, I.C., Gunnink, H., and Van Harn, J. (2014). Wet litter not only induces footpad dermatitis but also reduces overall welfare, technical performance, and carcass yield in broiler chickens. American Historical Review 119, 51-58.

De Jong, I. C., H. Enting, S. Van Voorst, E. W. Ruesink, and H. J. Blokhuis. 2005. Do Low Density Diets Improve Broiler Breeder Welfare During Rearing and Laying? Poultry Science 84:194-203. 
De Jong, I. C., and D. Guemene. 2011. Major welfare issues in broiler breeders. Worlds Poult. Sci. J. 67:73-81. doi 10.1017/s0043933911000067

De Gussem, M., Van Middelkoop, K., Van Mullem, K., Van 't Veer, E. (2014). Broiler signals. Roodbont Publishers, Zutphen, the Netherlands

Defra (2002). Meat Chickens and Breeding Chickens, in: Code of recommendations for the welfare of livestock, PB7275.

Degen, A.A., and Kam, M. (1998). Roosters prefer cool drinking water in both summer and winter. Journal of Applied Poultry Research 7, 258-262.

Donkoh, A. (1989). Ambient temperature: a factor affecting performance and physiological response of broiler chickens. International Journal of Biometeorology 33, 259-265.

EFSA. (2010a). Scientific opinion on the influence of genetic parameters on the welfare and resistance to stress of commercial broilers. EFSA journal 2010: 8 (7) 1666.

EFSA. (2010b). Scientific opinion on welfare apsects of the management and housing of the grandparent and parent stocks raised and kept for breeding purposes. EFSA journal 2010: 8(7) 1667.

Eichner, G., Vieira, S.L., Torres, C.A., Coneglian, J.L.B., Freitas, D.M., and Oyarzabal, O.A. (2007). Litter moisture and footpad dermatitis as affected by diets formulated on an all-vegetable basis or having the inclusion of poultry by-product. Journal of Applied Poultry Research 16, 344-350.

Elson, H.A. (2010). Poultry housing and husbandry. British Poultry Science 51, 23-34.

Elson, H.H. (1989). Drinker design affects litter quality. Poultry 5, 8-9.

Enting, H. J. de Los Mozos, A. Gutiérrrezdel Álamo and P. Pérezde Ayala (2009). Influence of minerals on litter moisture. In: Proceedings \& Abstracts 17th European Symposium on Poultry Nutrition 2327 August 2009, Edinburgh - Scotland

Fairchild, B., Batal, A., Ritz, C., and Vendrell, P. (2005a). Effect of drinking water iron concentration on broiler performance. Poultry Science 84, 16-16.

Fairchild, B.D., Batal, A.B., and Ritz, C.W. (2006a). Effect of drinking water iron nitrate, and manganese on broiler performance. Poultry Science 85, 116-116.

Fairchild, B.D., Batal, A.B., Ritz, C.W., and Vendrell, P.F. (2006b). Effect of drinking water iron concentration on broiler performance. Journal of Applied Poultry Research 15, 511-517.

Fairchild, B.D., Mauldin, J.M., Northcutt, J.K., Cole, M.B., Darby, M.D., and Buhr, R.J. (2005b). The effect of holding time without water on broiler performance, yolk sac retention and gut integrity. Poultry Science 84, 33-33.

Fairchild, B.D., Northcutt, J.K., Mauldin, J.M., Buhr, R.J., Richardson, L.J., and Cox, N.A. (2006c). Influence of water provision to chicks before placement and effects on performance and incidence of unabsorbed yolk sacs. Journal of Applied Poultry Research 15, 538-543.

Fairchild, B.D., and Ritz, C.W. (2012). Poultry drinking water primer, in: Bull. 1301. Cooperative Extension. ( Athens, US: University of Georgia).

Feddes, J.J.R., Emmanuel, E.J., and Zuidhof, M.J. (2002). Broiler performance, body weight variance, feed and water intake, and carcass quality at different stocking densities. Poultry Science 81, 774779.

Feddes, J.J.R., Emmanuel, E.J., Zuidhof, M.J., and Korver, D.R. (2003). Ventilation Rate, Air Circulation, and Bird Disturbance: Effects on the Incidence of Cellulitis and Broiler Performance. Journal of Applied Poultry Research 12, 328-334.

Franchina, J.J., Dyer, A.B., Zaccaro, S.J., and Schulman, A.H. (1986). Socially Facilitated Drinking Behavior in Chicks (Gallus-Domesticus) - Relative Effects of Drive and Stimulus Mechanisms. Animal Learning \& Behavior 14, 218-222.

Ganchrow, D., and Ganchrow, J.R. (1985). Number and Distribution of Taste-Buds in the Oral Cavity of Hatchling Chicks. Physiology \& Behavior 34, 889-894.

GD, z.d. http://www.gddiergezondheid.nl/diergezondheid/management/drinkwater/wateronderzoek)

Goldstein, D.L. and E. Skadhauge. (2000). Renal and extrarenal regulation of body fluid compostion. In: Sturkie's Avian Physiology. Ed. G.C. Whittow. Academic Press, San Diego, USA, pp. 265-297.

Grizzle, J., Armbrust, T., Bryan, M., and Saxton, A. (1996). Water quality .1. The effect of water nitrate and $\mathrm{pH}$ on broiler growth performance. Journal of Applied Poultry Research 5, 330-336.

Grizzle, J.M., Armbrust, T.A., Bryan, M.A., and Saxton, A.M. (1997a). Water quality .2. The effect of water nitrate and bacteria on broiler growth performance. Journal of Applied Poultry Research 6, 48-55. 
Grizzle, J.M., Armbrust, T.A., Bryan, M.A., and Saxton, A.M. (1997b). Water quality .3. The effect of water nitrate and bacteria on broiler breeder performance. Journal of Applied Poultry Research 6, 56-63.

Hayne, H., Roveecollier, C., Collier, G., Tudor, L., and Morgan, C.A. (1996). Learning and retention of conditioned aversions by freely feeding chicks. Developmental Psychobiology 29, 417-431.

Heidweiller, J., Vanloon, J.A., and Zweers, G.A. (1992). Flexibility of the Drinking Mechanism in Adult Chickens (Gallus-Gallus) (Aves). Zoomorphology 111, 141-159.

Heidweiller, J., and Zweers, G.A. (1992). Development of Drinking Mechanisms in the Chicken (GallusGallus) (Aves). Zoomorphology 111, 217-228.

Henuk, Y.L. and Dingle, J.G. 2003. Poultry manure: Source of fertilizer, fuel and fed. World's Poult. Sci. J. 59:350-360.

Hocking, P., Weeks, C., and Butterworth, A. (2004). Measuring and auditing the welfare of broiler breeders. Measuring and auditing broiler welfare, 19-35.

Hocking, P.M. (1993). Welfare of Broiler Breeder and Layer Females Subjected to Food and Water Control during Rearing - Quantifying the Degree of Restriction. British Poultry Science 34, 53-64.

Hocking, P.M., Maxwell, M.H., and Mitchell, M.A. (1993). Welfare assessment of broiler breeder and layer females subjected to food restriction and limited access to water during rearing. British Poultry Science 34, 443-458.

Hocking, P.M., Maxwell, M.H., and Mitchell, M.A. (1996). Relationships between the degree of food restriction and welfare indices in broiler breeder females. British Poultry Science 37, 263-278.

Hoppitt, W., and Laland, K.N. (2008). Social processes affecting feeding and drinking in the domestic fowl. Animal Behaviour 76, 1529-1543.

Houldcroft, E., Smith, C., Mrowicki, R., Headland, L., Grieveson, S., Jones, T.A., and Dawkins, M.S. (2008). Welfare implications of nipple drinkers for broiler chickens. Animal Welfare 17, 1-10.

Houpt, T.R. 2004. Water and electrolytes. In: Dukes physiology of domestic animals. 12th edition. Ed. W.O. Reece, Cornell University Press, USA.

Hubbard (2014). Broiler Management Guide.

Iheukwumere, F.C. and U. Herbert. (2003). Physiological responses of broiler chickens to quantitative water restrictions: Haematology and serum biochemistry. Int. J. Poult. Sci. 2:117-119.

IKB (2016). BIJLAGE 1.2A: VOORSCHRIFTEN IKB KIP ALLE PLUIMVEEBEDRIJVEN. https://pluimned.avined.nl/sites/pluimned.avined.nl/files/1.2voorschriften_pluimveebedrijven_ikb_kip_versie_6_-_20160501.pdf

Jones, E.K.M., Zaczek, V., Macleod, M., and Hocking, P.M. (2004). Genotype, dietary manipulation and food allocation affect indices of welfare in broiler breeders. British Poultry Science 45, 725-737.

Jones, F.T., and E, W.S. (2009). How does taste influence water consumption in broilers? Avian Advice $11,8-11$.

Jones, R.B., and Roper, T.J. (1997). Olfaction in the domestic fowl: A critical review. Physiology \& Behavior 62, 1009-1018.

Jong, I.C.D., Gunnink, H., and Harn, J.V. (2014). Wet litter not only induces footpad dermatitis but also reduces overall welfare, technical performance, and carcass yield in broiler chickens. Journal of Applied Poultry Research 23, 51-58.

Jong, I.C.D., and Harn, J.V. (2012). New approaches in housing and management to improve foot pad health in fattening poultry. Aviagen Technical Information.

Jong, I.C.D., Lourens, A., and Harn, J.V. (2015). Effect of hatch location and diet density on footpad dermatitis and growth performance in broiler chickens. Journal of Applied Poultry Research 24, 105-114.

Kare, M.R. (1970). The chemical senses of birds. [Online]. Available: digitalcommons.unl.edu/cgi/viewcontent.cgi?ar ticle=1183\&context=icwdmbirdcontrol [Accessed].

Kestin, S.C., Gordon, S., Su, G., and Sorensen, P. (2001). Relationships in broiler chickens between lameness, liveweight, growth rate and age. Veterinary Record 148, 195-197.

Knowles, T.G., R.C. Ball, P.D. Warriss, and J.E. Edwards. (1996). A survey to investigate potential dehydration in slaughtered broiler chickens. Br. Vet. J. 152:307-314.

Knowles, T.G., Kestin, S.C., Haslam, S.M., Brown, S.N., Green, L.E., Butterworth, A., Pope, S.J., Pfeiffer, D., and Nicol, C.J. (2008). Leg Disorders in Broiler Chickens: Prevalence, Risk Factors and Prevention. Plos One 3

Knowles, T.G., P.D. Warriss, S.N. Brown, J.E. Edwards, and M.A. Mitchell. 1995. Response of broilers to deprivation of food and water for 24 hours. Br. Vet. J. 151:197-202. 
Koike, T.I., Pryor, L.R., and Neldon, H.L. (1983). Plasma-Volume and Electrolytes during Progressive Water-Deprivation in Chickens (Gallus-Domesticus). Comparative Biochemistry and Physiology aPhysiology 74, 83-87.

Kostal, L., Savory, C.J., and Hughes, B.O. (1992). Diurnal and individual variation in behaviour of restricted-fed broiler breeders. Applied Animal Behaviour Science 32, 361-374.

Laverty, G., and E. Skadhauge. (1999). Physiological roles and regulation of transport activities in the avian lower intestine. J. Exp. Zool. 283:481-494.

Laverty, G. and E. Skadhauge. (2008.) Adaptive strategies for post-renal handling of urine in birds. Comp. Biochem. Physiol., Part. A. Mol. Intregr. Physiol. 149:246-254.

Leeson, S., J.D. Summers, and E.T. Moran Jr. (1976). Avian water metabolism - A review. Worlds Poult. Sci. J. 32:185-195.

Lin, H., Jiao, H.C., Buyse, J., and Decuypere, E. (2006). Strategies for preventing heat stress in poultry. World's Poultry Science Journal 62, 71-85.

Lott, B.D. (1991). The Effect of Feed-Intake on Body-Temperature and Water-Consumption of Male Broilers during Heat Exposure. Poultry Science 70, 756-759.

Lott, B.D., Dozier, W.A., Simmons, J.D., and Rouch, W.B. (2003). Water flow rates in commercial broiler houses. Poultry Science 82, 102 (S156).

Lott, B.D., Simmons, J.D., and May, J.D. (1998). Air velocity and high temperature effects on broiler performance. Poultry Science 77, 391-393.

Manning, L., Chadd, S.A., and Baines, R.N. (2007a). Key health and welfare indicators for broiler production. World's Poultry Science Journal 63, 46-62.

Manning, L., Chadd, S.A., and Baines, R.N. (2007b). Water consumption in broiler chicken: A welfare indicator. World's Poultry Science Journal 63, 63-71.

Marks, H.L. (1987). Water and Feed-Intake, Feed-Efficiency, and Abdominal Fat Levels of Dwarf and Normal Chickens Selected under Different Water - Feed Ratio Environments. Poultry Science 66, 1895-1900.

Marks, H.L., and Brody, T. (1984). Intakes of feed and water following restriction in selected and nonselected broilers. Poultry science 63, 2307-2317.

Marples, N.M., and Roper, T.J. (1996). Effects of novel colour and smell on the response of naive chicks towards food and water. Animal Behaviour 51, 1417-1424.

May, J.D., Lott, B.D., and Simmons, J.D. (2000). The effect of air velocity on broiler performance and feed and water consumption. Poultry Science 79, 1396-1400.

Mcilroy, S.G., Goodall, E.A., and Mcmurray, C.H. (1987). A Contact-Dermatitis of Broilers Epidemiologic Findings. Avian Pathology 16, 93-105.

Mckinley, M.J., Cairns, M.J., Denton, D.A., Egan, G., Mathai, M.L., Uschakov, A., Wade, J.D., Weisinger, R.S., and Oldfield, B.J. (2004). Physiological and pathophysiological influences on thirst. Physiology \& Behavior 81, 795-803.

Mckinley, M.J., and Johnson, A.K. (2004). The physiological regulation of thirst and fluid intake. News in Physiological Sciences 19, 1-6.

Mench, J.A. (2002). Broiler breeders: feed restriction and welfare. Worlds Poultry Science Journal 58, 23-29.

Miles, D.M., Lott, B.D., Branton, S.L., and Simmons, J.D. (2004). Development of a water stick to measure nipple waterer flow rates. Journal of Applied Poultry Research 13, 258-262.

Mushtaq, M.M.H., Pasha, T.N., Mushtaq, T., Akram, M., Mahmood, S., Farooq, U., and Parvin, R. (2014). Growth, water intake, litter moisture, carcass and physiological traits of broiler chickens fed varying levels and sources of potassium under phase feeding system. Livestock Science 159, 61-66.

Mushtaq, M.M.H., Pasha, T.N., Mushtaq, T., and Parvin, R. (2013). Electrolytes, dietary electrolyte balance and salts in broilers: An updated review on growth performance, water intake and litter quality. World's Poultry Science Journal 69, 789-802.

Newberry, R.C., Hunt, J.R., and Gardiner, E.E. (1988). Influence of light intensity on behavior and performance of broiler chickens. Poultry science 67, 1020-1025.

Nielsen, B.L., Thodberg, K., Malmkvist, J., and Steenfeldt, S. (2011). Proportion of insoluble fibre in the diet affects behaviour and hunger in broiler breeders growing at similar rates. Animal 5, 12471258. 
Oliveira, P.M., Faria, M.J.A., and Neto, M.G. (2016). Strategies to minimize the adverse thermal environment in broiler chickens. Arquivo Brasileiro De Medicina Veterinaria E Zootecnia 68, 739747.

Pedersen, S., and Thomsen, M.G. (2000). Heat and moisture production of broilers kept on straw bedding. Journal of Agricultural Engineering Research 75, 177-187.

Pesti, G.M., Amato, S.V., and Minear, L.R. (1985). Water-Consumption of Broiler-Chickens under Commercial Conditions. Poultry Science 64, 803-808.

Pesti, G.M., and Marks, H.L. (1983). The Influence of Dietary-Protein Level on Water-Intake and Abdominal Fat Pad Weights in Broilers. Poultry Science 62, 1482-1483.

Pinchasov, Y., Nir, I., and Nitsan, Z. (1987). Water Intake And Water Concentration In The Body And Gastrointestinal Tract Of Intermittently Fed Broiler Chickens. British Poultry Science 28, 287-294.

Pollock, C. (2006). Diagnosis and treatment of avian renal disease. The veterinary clinics of North America. Exotic animal practice 9:107-128. doi 10.1016/j.cvex.2005.10.007

Puma, M. C., H. Xin, R. S. Gates, and D. J. Burnham. (2001). An instrumentation system for studying feeding and drinking behavior of individual poultry. Appl Eng Agric 17:365-374.

Quichimbo, C., Quintana, J., Rodríguez-Saldaña, D., López-Coello, C., Gómez, S., and Castellanos, F. (2013). Effect of nipple type drinker height on productive parameters of broilers. International Journal of Poultry Science 12, 144-147.

Radin, M.J., Swayne, D.E., Gigliotti, A., and Hoepf, T. (1996). Renal function and organic anion and cation transport during dehydration and/or food restriction in chickens. Journal of Comparative Physiology B-Biochemical Systemic and Environmental Physiology 166, 138-143.

Rexhepi, A., C. Brown, K. Sherifi, and B. Behluli. 2015. Visceral Gout (Uricosis) and Urolithiasis Caused by Dehydration in Laying Hen Farm, Necropsy and Histopathology Findings. Kafkas Univ. Vet. Fak. Derg. 21:291-294. doi 10.9775/kvfd.2014.12238.

Ritz, C.W., Batal, A.B., Fairchild, B.D., and Sedlacek, P. (2006). Effect of drinking water nitrate on broiler performance. Poultry Science 85, 109-109.

Ross, P. A., and J. F. Hurnik. 1983. Drinking Behavior of Broiler Chicks. Appl Anim Ethol 11:25-31. doi Doi 10.1016/0304-3762(83)90076-7.

Ross, P. A., J. F. Hurnik, and W. D. Morrison. 1981. Effect of Controlled Drinking Time on FeedingBehavior and Growth of Young Broiler Breeder Females. Poultry Science 60:2176-2181.

Saito, N. and R. Grossmann. (1998). Effects of short-term dehydration on plasma osmolality, levels of arginine vasotocin and its hypothalamic gene expression in the laying hen. Comp. Biochem. Physiol. Part A 121:235-239.

Sandilands, V., Tolkamp, B.J., and Kyriazakis, I. (2005). Behaviour of food restricted broilers during rearing and lay - effects of an alternative feeding method. Physiology \& Behavior 85, 115-123.

Sanotra, G.S., Lund, J.D., and Vestergaard, K.S. (2002). Influence of light-dark schedules and stocking density on behaviour, risk of leg problems and occurrence of chronic fear in broilers. British Poultry Science 43, 344-354.

Savory, C.J. (1978). The Relationship Between Food And Water Intake And The Effects Of Water RestricTion On Laying Brown Leghorn Hens. British Poultry Science 19, 631-641.

Savory, C.J., and Maros, K. (1993). Influence of Degree of Food Restriction, Age and Time of Day on Behavior of Broiler Breeder Chickens. Behavioural Processes 29, 179-190.

SCAHAW. (2000). The Welfare of Chickens Kept for Meat Production (Broilers). EUROPEAN COMMISSION HEALTH \& CONSUMER PROTECTION DIRECTORATE-GENERAL, 149 pp.

Schafer, U. (2012). Evaluation of beneficial and adverse effects on plants and animals following lithium deficiency and supplementation, and on humans following lithium treatment of mood disorders. Trace Elements and Electrolytes 29, 91-112.

Senaratna, D., Samarakone, T.S., and Gunawardena, W.W.D.A. (2016). Red color light at different intensities affects the performance, behavioral activities and welfare of broilers. Asian-Australasian Journal of Animal Sciences 29, 1052-1059.

Shepherd, E. M., and B. D. Fairchild. (2010). Footpad dermatitis in poultry. Poultry Science 89:20432051.

Shields, S. J., J. P. Garner, and J. A. Mench. (2004). Comparison of the behavior of broiler chickens raised on two different bedding types. Poultry Science 83:83-83.

SMK, (2016). Criteria voor Vleeskuikens met normen voor milieukeur http://www.milieukeur.nl/Public/Milieukeur_Agro_Food_Dierlijke_Producten_Schema/DP19VLK.pdf 
Sprenger, M., Vangestel, C., and Tuyttens, F.a.M. (2009). Measuring thirst in broiler chickens. Animal Welfare 18, 553-560.

Svihus, B., M. Choct, and H.L. Classen. (2013). Function and nutritional roles of the avian caeca: A review. Worlds Poult. Sci. J. 69:249-264.

Syafwan. (2012). Effects of dietary changes on heat stress in broiler and Kampung chickens. PhD thesis, Wageningen University, Wageningen, the Netherlands.

Tabler, G.T. (2003). Water intake: A good measure of broiler performance. Avian Advice 5, 7-9.

Tabler, T., Wells, J., and Zhai, W. (2012). Water-Related Factors in Broiler Production, in: Extension Service of Mississippi State University. (POD-11-12) ed. (Missisippi: Mississippi State University).

Teeter, R.G., and Belay, T. (1996). Broiler management during acute heat stress. Animal Feed Science and Technology 58, 127-142.

The University of Tennessee Agricultural Extension Service, P.-M.-., and E12-2015-00-151-95. (1994). PB1533-Nipple Watering Systems for Broilers.

Thomas, D.H. 1982. Salt and water excretion in birds: The lower intestine as an integrator of renal and intestinal excretion. Comp. Biohem. Physiol. A Physiol. 71:527-535.

Toghyani, M., Toghyani, M., Shahryar, H.A., and Zamanizad, M. (2011). Assessment of growth performance, immune responses, serum metabolites, and prevalence of leg weakness in broiler chicks submitted to early-age water restriction. Tropical Animal Health and Production 43, 11831189.

Tullo, E., Fontana, I., Peña Fernandez, A., Berckmans, D., Koenders, E., Vranken, E., Brown, S.N., Butterworth, A., Gunnink, H., and Guarino, M. (2015). Risk factor for footpad dermatitis and hock burns in broiler chickens, in: Precision Livestock Farming 2015 - Papers Presented at the 7th European Conference on Precision Livestock Farming, ECPLF 2015, 792-800.

Tuyttens, F.A.M., F. Vanhonacker, E. van Poucke, and W. Verbeke. (2010). Quantitative verification of the correspondence between the Welfare Quality ${ }^{\circledR}$ operational definition of farm animal welfare and the opinion of Flemisch farmers, citizens and vegetarians. Livest. Sci. 131:108-114.

Van Harn, J., and de Jong, I.C. (2012). Zuur is zoet voor zolen (1). De Pluimveehouderij 42, 28-29.

Van Harn, J., de Jong, I.C., and Gunnink, H. (2015). Wet litter not only induces footpad dermatitis but also reduces overall welfare, technical performance and carcass yields in broiler chickens, in: Book of Abstracts of the XIVth European poultry conference: The world's poultry science association, 416-416.

Van Harn, J., de Jong, I.C, and Veldkamp, T. (2009). Effect strooiselmateriaal, strooiselhoeveelheid, opvangschoteltjes en waterdruk op resultaten vleeskuikens = Influence of bedding material, bedding amount, drip cup and reduced water pressure on broiler performance". Lelystad: Animal Sciences Group, Report 220.

Van Harn, J., Neijenhuis, F., and Ellen, H.H. (2014). Drinkwaterkwaliteit - vleeskuikenhouders: controleer regelmatig uw drinkwaterkwaliteit! : Wageningen UR Livestock Research.

Van Harn, J., (2008). Invulling lichteisen EU-welzijnsrichtlijn voor vleeskuikens - vier lichtschema's vergeleken. ASG Rapport 172.

Van Harn, J en I.C. de Jong, (2012). Ander merk in de stal. Pluimveehouderij 20 april 2012, p. 26-27. Traaggroeiende kuikens hebben een lagere water/voer verhouding dan snelgroeiende kuikens.

Van Horne, P.L.M.; Harn, J. van; van Middelkoop, J.H.; Tacken, G.M.L. (2003) Perspectieven voor een alternatieve kuikenvleesketen; Marktkansen voor een langzaam groeiend vleeskuiken. Den Haag : LEI, (Rapport LEI 2.03.20).

Van Der Hoeven-Hangoor, E. (2014). Broiler excreta composition and its effect on wet litter- Aspects of nutrition. Wageningen University.

Van Middelkoop, J.H en J. van Harn, (1995). Vergelijkend onderzoek drinkwatersystemen vleeskuikens - Eindrapportage FOMA. PP-uitgave no. 23 Praktijkonderzoek Pluimveehouderij.

Vanderhasselt, R. (2013). Imporoving the assessment of thirst and footpad dermatitis in broiler chicken welfare monitoring schemes. PhD Thesis, Ghent University.

Vanderhasselt, R., M. Sprenger, F.A.M. Tuyttens, D. De Brabander, O. Cangar, C. Bahr, D. Berckmans, E. Vranken, E. Decuypere, J. Buyse, D. Lips, M. Cox, K. De Baere, and J. Zoons. (2010). Welzijnsnormen bij vleeskippen. FOD. Report project nr. RT-06/4.

Vanderhasselt, R.F., Goethals, K., Buijs, S., Federici, J.F., Sans, E.C.O., Molento, C.F.M., Duchateau, L., and Tuyttens, F.a.M. (2014). Performance of an animal-based test of thirst in commercial broiler chicken farms. Poultry Science 93, 1327-1336. 
Vieira, S.L., and Lima, I.L. (2005). Live performance, water intake and excreta characteristics of broilers fed all vegetable diets based on corn and soybean meal. International Journal of Poultry Science 4, 365-368.

Viola, T.H., Ribeiro, A.M.L., Penz Júnior, A.M., and Viola, E.S. (2009). Influence of water restriction on the performance and organ development of young broilers. Revista Brasileira de Zootecnia 38, 323-327.

Visser, K., Rommers, J., Ruis, M., Gerritzen, M., Veldkamp, T. \& de Jong, I. (2015). Risicoanalyse dierenwelzijn witvleesketen. Wageningen UR Livestock Research Report 884. http://www.wageningenur.nl/en/Expertise-Services/Research-Institutes/livestockresearch/publications.htm.

Watkins, S. and G.T. Tabler. (2009). Broiler water consumption. Avian Advice 13:11-12.

Wet Dieren (2014). http://wetten.overheid.nl/BWBR0030250/2015-02-01

Williams, R.B. (1996). The ratio of the water and food consumption of chickens and its significance in the chemotherapy of coccidiosis. Vet. Res. Commun. 20:437-447.

Weeks, C.A., and Butterworth, A. (2004). Measuring and Auditing Broiler Welfare. Wallingford UK: CABI publishing.

Welfare Quality. (2009). Welfare Quality welfare assessment protocol for poultry. The Welfare Quality Consortium.

Winn, P.N., and Godfrey, E.F. (1967). The effect of humidity on growth and feed conversion of broiler chickens. International Journal of Biometeorology 11, 39-50.

Yeomans, M.R. (1986). Overdrinking in the Domestic-Fowl. British Poultry Science 27, 163-163.

Zhou, W.T., M. Fujita, and S. Yamamoto. (1998). Effects of food and water withdrawal and high temperature exposure on diurnal variation in blood viscosity of broiler chickens. Br. Poult. Sci. 39:156-160.

Zuidhof, M. J., B. L. Schneider, V. L. Carney, D. R. Korver, and F. E. Robinson. (2014). Growth, efficiency, and yield of commercial broilers from 1957, 1978, and 2005. Poultry Science 93:29702982. doi 10.3382/ps.2014-04291. 


\section{Bijlage 1 Geraadpleegde stakeholders}

Vleeskuikens:

- Specialist vleeskuikens, veevoedersector, 9 jaar ervaring

- Pluimvee dierenartsen, gespecialiseerde vleeskuikenpraktijk, als groep geraadpleegd, 5, 25 en 27 jaar ervaring

- Specialist vleeskuikens en hoofd afdeling vleespluimvee, veevoedersector en vleeskuikenhouder, ervaring als specialist vleeskuikens $>10$ jaar

- Technisch specialist vleeskuikens, veevoedersector, 27 jaar ervaring

- Commercieel technisch manager, fokbedrijf, 30 jaar ervaring

Specialisten vleeskuikens uit de veevoedersector hebben ruime ervaring bij zowel bedrijven met gangbare kuikens als bedrijven die produceren volgens de verschillende concepten met trager groeiende vleeskuikens.

Vleeskuikenouderdieren:

- Commercieel technisch manager, fokbedrijf, 30 jaar ervaring

- Pluimvee dierenarts, gespecialiseerde praktijk voor opfok en vermeerdering vleeskuikenouderdieren, 26 jaar ervaring

- Pluimvee specialist, veevoedersector, 5 jaar ervaring

- Technisch directeur, fokbedrijf, 35 jaar ervaring

De geraadpleegde stakeholders hebben ervaring met zowel bedrijven met gangbare ouderdieren als bedrijven met ouderdieren van trager groeiende vleeskuikens. 


\title{
Bijlage 2 Vragenlijst stakeholders
}

De volgende vragenlijst is gebruikt bij de stakeholder consultatie:

\author{
Algemene informatie: \\ Expert naam: \\ Interviewdatum: \\ Bedrijf: \\ Functie: \\ Aantal jaren in deze of vergelijkbare functie: \\ Interviewer: \\ Overige opm:
}

\section{Welke factoren zijn naar uw mening van invloed op de wateropname?}

Kruis aan in de lijst. Vul de lijst aan met ontbrekende factoren.

Rangschikking: rangschik op basis van de mate van effect op wateropname, en maximaal 10 factoren (maximaal een top 10 van meest belangrijke factoren).

\section{Lijst van factoren:}

Factor

lichtschema

lichtsterkte

soort licht (daglicht/kunstmatig)

voersamenstelling

voerregime (beperkt/onbeperkt)

bijvoeren hele tarwe

strooiseltype

type drinker

afstand tussen drinkpunten/waterlijnen

waterdruk

reinheid water

additieven in drinkwater

ras/merk

geslacht

leeftijd

darmgezondheid

ventilatiedebiet

wijze van ventileren

temperatuurschema

werkelijke staltemperatuur

relatieve luchtvochtigheid

stofconcentratie

ammoniakconcentratie

mobiliteit kuikens

luchtweggezondheid

gezondheid/vitaliteit koppel algemeen

antibiotica toediening

vaccinatietoediening

vaccinatieschema

uitkomstmethode (broederij/stal/hatchbrood)

afleidingsmateriaal

Wijze van huisvesting (emissiearm stalsysteem)

Bezettingsdichtheid 
Geef voor iedere factor aan of deze invloed heeft op de wateropname, geef kort weer wat de invloed dan is, en rangschik de factoren naar mate van invloed op wateropname (voor maximaal 10 factoren).

\section{Praktijksituatie}

Op hoeveel bedrijven vindt beperkte respectievelijk onbeperkte waterverstrekking plaats (inschatting in percentage)?

Maak voor vleeskuikenouderdieren onderscheid tussen opfokperiode en productieperiode.

Indien water beperkt wordt verstrekt, welke methoden worden daarbij dan toegepast in de praktijk? Beschrijf deze methoden, bijvoorbeeld het aantal uren dat de kraan dicht zit, of wat een lage waterdruk inhoudt.

Indien water beperkt wordt verstrekt, heeft dat dan gevolgen voor diergezondheid, dier/koppelgedrag, dierfysiologie, productie, anders?

Bij anders, denk ook aan bv. Verstrekken geneesmiddelen via het water, vervuiling leidingen, uitwendige kwaliteit/afkeur, stalklimaat/stof, strooiselkwaliteit.

Scoor de ernst van het effect: $0=$ geen effect; 3 =ernstig/groot effect

Geef korte toelichting van effect (bv. Hoe wordt de gezondheid beïnvloed)

Alleen voor vleeskuikenouderdieren:

Indien onbeperkt water wordt verstrekt bij gecontroleerd (beperkt) gevoerde dieren, heeft dat dan een effect op diergezondheid, dier(koppel)gedrag, dierfysiologie, productie of anderszins?

Denk bij anders ook aan bv. verstrekking geneesmiddelen of additieven via het water, vervuiling leidingen e.d., klimaat, luchtkwaliteit (stof), strooiselkwaliteit.

Zijn er nog andere opmerkingen die $u$ wil plaatsen in relatie tot methoden van waterverstrekking en de mogelijke effecten daarvan op gezondheid, welzijn, productie of anderszins? 

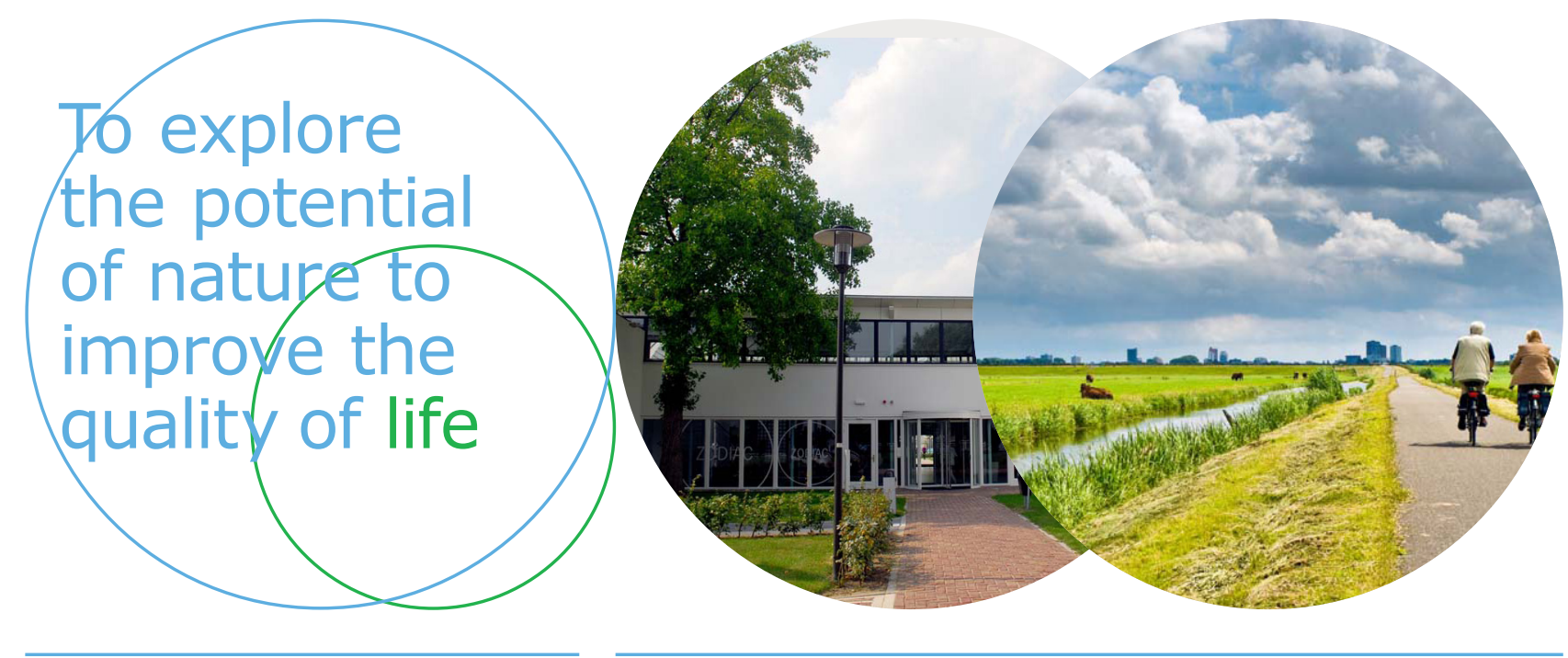

Wageningen Livestock Research Postbus 338

6700 AH Wageningen

T 0317483953

E info.livestockresearch@wur.nl www.wur.nl/livestock-research
Wageningen Livestock Research ontwikkelt kennis voor een zorgvuldige en renderende veehouderij, vertaalt deze naar praktijkgerichte oplossingen en innovaties, en zorgt voor doorstroming van deze kennis. Onze wetenschappelijke kennis op het gebied van veehouderijsystemen en van voeding, genetica, welzijn en milieu-impact van landbouwhuisdieren integreren we, samen met onze klanten, tot veehouderijconcepten voor de $21 \mathrm{e}$ eeuw.

De missie van Wageningen University \& Research is 'To explore the potential of nature to improve the quality of life'. Binnen Wageningen UR bundelen 9 gespecialiseerde onderzoeksinstituten van stichting DLO en Wageningen University hun krachten om bij te dragen aan de oplossing van belangrijke vragen in het domein van gezonde voeding en leefomgeving. Met ongeveer 30 vestigingen, 6.000 medewerkers en 10.000 studenten behoort Wageningen UR wereldwijd tot de aansprekende kennisinstellingen binnen haar domein. De integrale benadering van de vraagstukken en de samenwerking tussen verschillende disciplines vormen het hart van de unieke Wageningen aanpak. 